
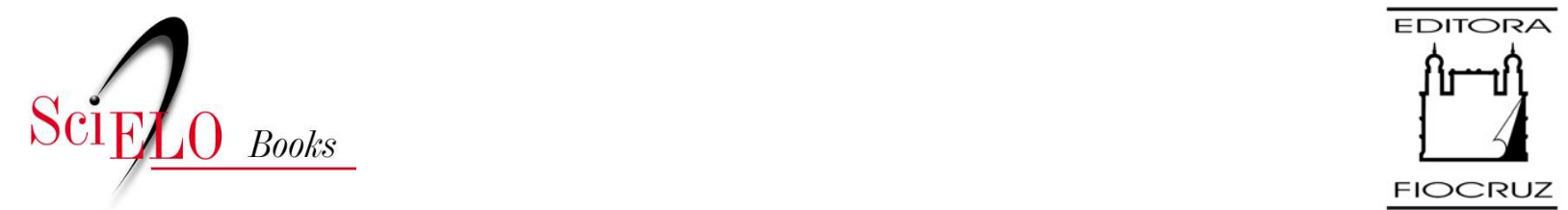

\title{
Vigilância alimentar e nutricional: limitações e interfaces com a rede de saúde
}

\author{
Inês Rugani R. de Castro
}

SciELO Books / SciELO Livros / SciELO Libros

CASTRO, IRR. Vigilância alimentar e nutricional: limitações e interfaces com a rede de saúde [online]. Rio de Janeiro: Editora FIOCRUZ, 1995. 108 p. ISBN 85-85676-12-4. Available from SciELO Books <http://books.scielo.org $>$.

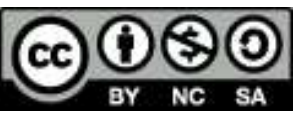

All the contents of this chapter, except where otherwise noted, is licensed under a Creative Commons Attribution-Non Commercial-ShareAlike 3.0 Unported.

Todo o conteúdo deste capítulo, exceto quando houver ressalva, é publicado sob a licença Creative Commons Atribuição - Uso Não Comercial - Partilha nos Mesmos Termos 3.0 Não adaptada.

Todo el contenido de este capítulo, excepto donde se indique lo contrario, está bajo licencia de la licencia Creative Commons Reconocimento-NoComercial-CompartirIgual 3.0 Unported. 


\section{Vigilânaia Alimentar e Nutricional:}

Limitações e Interfaces com a Rede de Saúde

\section{Inês Rugani Ribeiro de Castro}
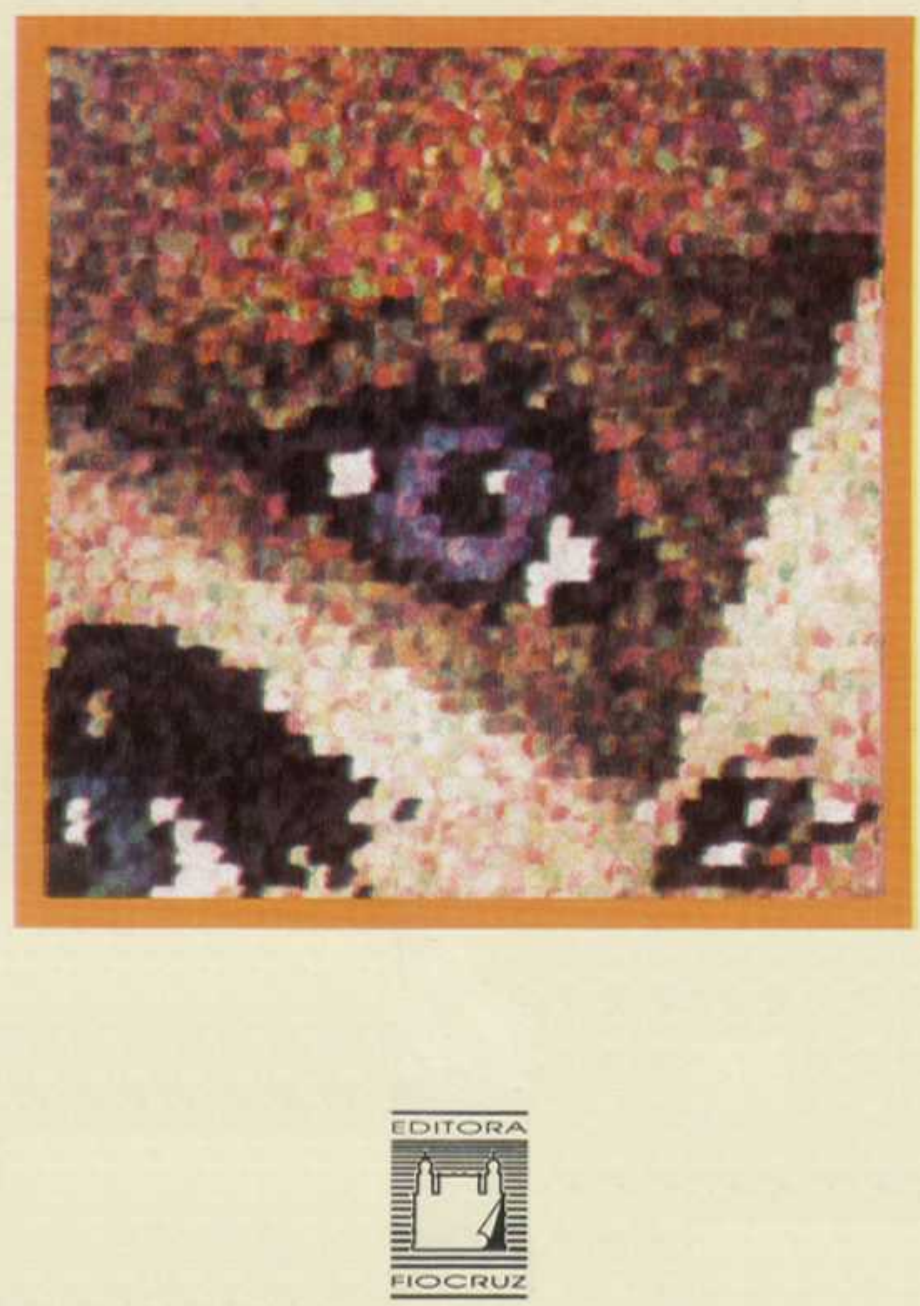
O Sistema de Vigilância Alimentar e Nutricional (SISVAN) é um enorme desafio, tal o alcance do seus discurso, em busca de uma equiidade que as Nações Unidas consideram desejável: a superação das desigua'dades retratadas no perfil epidemiológico das doenças relacionadas com a situação alimentar $e$ nutricional. $\mathrm{Na}$ busca deste objetivo maior, o SISVAN assumiu conceitos, direções, perplexidades, propostas, limitações e responsabilidades variadas $e$ às vezes conflitivas, como se depreende da excelente análise apresentada nesta obra pioneira.

Vigilancia Alimentar e Nutricional: Limitações e Interfaces com a Rede de Saúde consolida a contribuição brasileira no campo ainda indefinido da vigilância alimentar $e$ nutricional e tem todas as condições para se converter num marco historiográfico do tema. 
Inês Rugani Ribeiro de Castro

\section{Vigilância Alimentar e Nutricional:}

Limitaçōes e interfaces com a Rede de Saúde

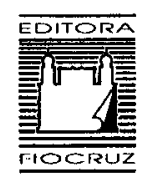


Copyright @ 1995 Inês Rugani Ribeiro de Castro

Todos os direito desta edição reservados à

EDITORA FIOCRUZ

ISBN: 85-85676-12-4

Capa: Roberto Antunes Moreira

Projeto Gráfico: Heloisa Diniz

Revisão: Marcionilio Cavalcanti de Paiva

C355v Castro, Inês Rugani R. de

Vigilância alimentar e nutricional : limitaçōes e interfaces com a rede de saúde/ Inês Rugani R. de Castro. Rio de Janeiro : FIOCRUZ, 1995.

108p. il. tab.

Inclui bibliografia.

1. Vigilância nutricional. 2. Assistência a saúde. 3. Sistema de saúde. 4. Cuidados primários de saúde. I. Título.

CDD - 20.ed. - 363.6

1995

EDITORA FIOCRUZ

Rua Leopoldo Bulhões, 1480 - Manguinhos

21041-210 - Rio de Janeiro - RJ

Tel.: 590-3789 r. 2009

Fax.: (021) 280-8194 


\section{Vigilância Alimentar e Nutricional:}

Limitaçōes e Interfaces com a Rede de Saúde 


\section{FUNDAÇÃO OSWALDO CRUZ}

Presidente

Carlos Médicis Morel

Vice-Presidente de Ensino e Informação

Paulo Marchiori Buss

\section{EDITORA FIOCRUZ}

Coordenador

Paulo Marchiori Buss

Conselho Editorial

Carlos E. A. Coimbra Jr.

Charles Pessanha

Hooman Momen

José da Rocha Carvalheiro

Luiz Fernando Ferreira

Paulo M. Buss

Sergio Goes de Paula

Zigman Brener

Coordenador Executivo

Francisco Edmilson M. Carneiro 
"Quando amanheceu veio o vento e arrancou a folha de seu galho. Não doeu. Ela sentiu que flutuava no ar, muito serena. $\mathrm{E}$, enquanto caia, ela viu a árvore inteira pela primeira vez. Como era forte e firme! Teve certeza de que a árvore viveria por muito tempo, compreendeu que fora parte de sua vida e isto deixou-a orgulhosa.

A folha pousou num monte de neve. Estava macio, até mesmo aconchegante. Naquela nova posição, a folha estava mais confortável do que jamais se sentira. Ela fechou os olhos e adormeceu. Não sabia que a primavera se seguiria ao inverno, que a neve derreteria e viraria água. Não sabia que a folha que fora, seca e aparentemente inútil, se juntaria com a água e serviria para tornar a árvore mais forte.

E, principalmente, não sabia que ali, na árvore e no solo, já havia planos para novas folhas na primavera."

Leo Buscaglia

A história de uma folha.

A Bia, maninha tão querida, por tudo que sonhamos e fizemos, e por tudo que não deu tempo. 


\section{Agradecimentos}

Agradeço a todos aqueles que, de formas e em momentos diversos, contribuiram para a elaboração de minha dissertação de mestrado - defendida em março de 1994 na Escola Nacional de Saúde Pública/Fiocruz - que deu origem a este livro. Agradeço, também, a Maria Helena D'Aquino Benício, por ter, gentilmente, revisado trechos da versão final do mesmo. Em especial, agradeço a

Alberto Lopes Najar, por sua absoluta cumplicidade, seu estímulo e sugestões, sempre lúcidas e criativas;

Luiz Antonio dos Anjos, por sua disponibilidade e apoio constantes ao longo de minha formação acadêmica, bem como pelas contribuições preciosas durante a elaboração da dissertação de mestrado e feitura deste livro, e a

Malaquias Batista Filho, por ter-me iniciado no tema aqui desenvolvido e por apoiar-me integralmente, de forma extremamente atenciosa, nesta empreitada. 


\section{Sumário}

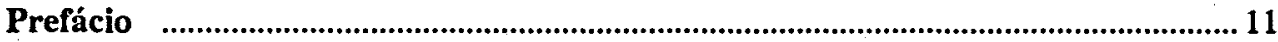

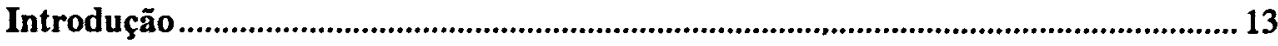

\section{Capítulo 1}

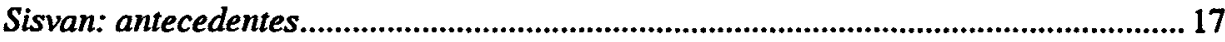

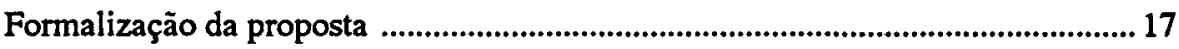

Evolução do Sisvan .................................................................................................2 20

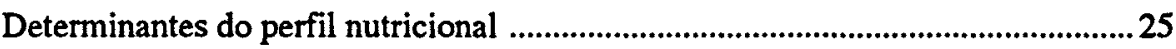

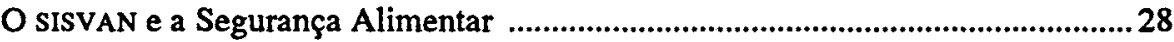

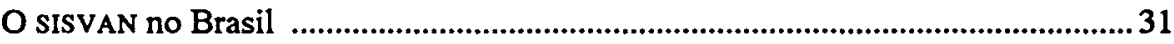

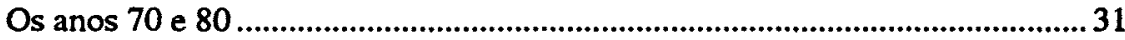

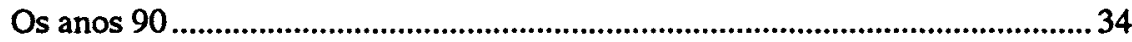

\section{Capítulo 2}

Saúde e nutrição da população brasileira ………….......................................................... 41

A transição epidemiológica ....................................................................................4 41

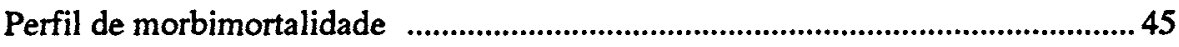

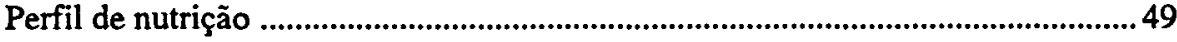

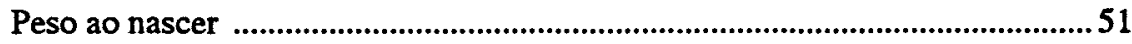

Crescimento de crianças .....................................................................................52

Situação nutricional de adultos ..........................................................................57

Situação nutricional de gestantes .........................................................................6 60

\section{Capítulo 3}

Vigilância epidemiológica e atenção à saúde ..................................................................63

Vigilância epidemiológica .................................................................................6

Programas de atenção integral à saúde ...............................................................67

Programa de Atenção Integral à Saúde da Criança (PAISC) ................................70

Programa de Atenção Integral à Saúde da Mulher (PAISM) ...............................71

Programa de Saúde do Adolescente (PROSAD) ....................................................72 


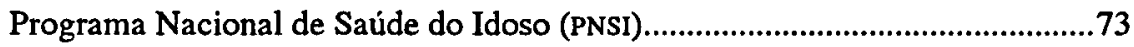

Programas voltados para a saúde do adulto ...................................................74

Programa de Controle do Diabetes Mellitus.................................................74

Programa Nacional de Educação e Controle da

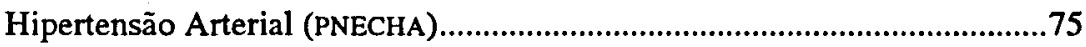

Capítulo 4

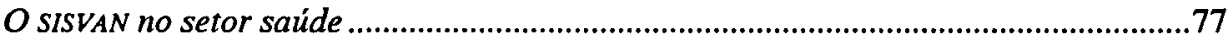

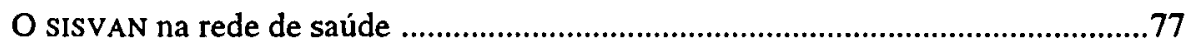

Sobre o marco teórico do planejamento multisetorial ........................................8

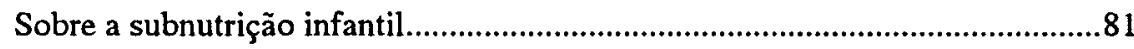

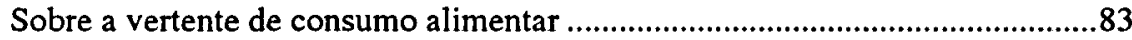

O sISVAN, a vigilância epidemiológica e a atenção integral à saúde .......................85

O SISVAN e a vigilância epidemiológica ..........................................................85

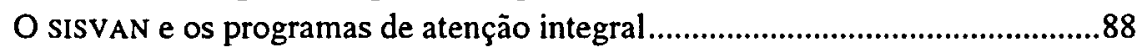

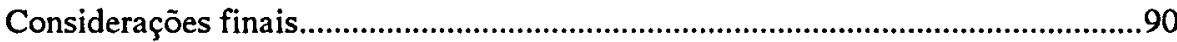

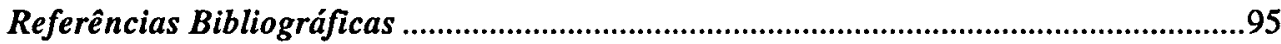




\section{Prefácio}

O tempo verbal do SISVAN acha-se no participio presente: é um instrumento que ainda está se fazendo, num processo construtivo elaborado mais a partir de conceitos que propriamente de usos validados interna e externamente pela experiência técnica, científica, política e administrativa. Sua história, de apenas vinte anos, alcançaria somente o limiar da maioridade formal de uma pessoa física, juridicamente autônoma para responder pelos próprios atos.

Pode parecer prematura, portanto, a resenha retrospectiva que Inês Rugani faz do SISVAN, numa abordagem meta-analítica, com o "agravante" de que a própria autora é também uma quase adolescente, com seus vinte e poucos anos de vida.

Na realidade, o estudo e a autora são exemplos ilustrativos e interativos de que não poderia existir um sistema métrico decimal para aferir, com a escala inelástica dos padrões, a compreensão dos fatos e processos mais recentes, face à própria aceleração que caracteriza os tempos modernos. Há muito mais densidade de eventos e de pensamentos nos vinte anos mais próximos do que no curso anterior de um século, face às mudanças "metamorfósicas" que marcam o ritmo exponencial dos fatos nos tempos atuais.

O SISVAN é um enorme desafio, tal o alcance de seu discurso, em busca de uma eqüidade que as Nações Unidas consideram desejável e possível: a superação das desigualdades retratadas no perfil epidemiológico das doenças relacionadas com a situação alimentar e nutricional. $\mathrm{Na}$ busca deste objetivo maior, o SISVAN assumiu conceitos, direções, perplexidades, propostas, limitações e responsabilidades variadas e às vezes conflitivas, como se depreende da excelente análise apresentada por Inês Rugani neste livro pioneiro que a Fiocruz em boa hora lança no mercado editorial, com todas as condições para se converter num marco historiográfico do SISVAN no Brasil e no mundo.

Mesmo sendo um livro para pensadores, trata-se de uma publicação de elevado alcance pragmático, na medida em que questiona e fornece elementos de de- 
cisão para os formuladores de políticas, planejadores e executores de programas e atividades de alimentação e nutrição, especialmente no contexto do setor saúde. Ainda com o risco de confessar sentimentos menores, é com uma sensação íntima (e aqui já explícita) de inveja que registro, como profissional em fim de carreira, o lançamento desta publicação que consolida a contribuição brasileira no campo ainda indefinido da vigilância alimentar e nutricional.

Valeu, Inês. Valeu pela equipe que você nomeia como atores da experiência pioneira da Escola Nacional de Saúde Pública. Valeu e vale pelos que fazem o SISVAN no Brasil e na América Latina, e que devem consultar este livro como uma referência obrigatória para se posicionar face às questões e desafios desta proposta inovadora e até revolucionária, que é a vigilância alimentar e nutricional.

Suas reflexões finais são antológicas, no sentido de se evitar o apriorismo "politicamente ingênuo, operacionalmente ambicioso, embora teoricamente elegante" mencionado pela ORALC/FAO, numa observação crítica sobre o modelo convencional da planificação nutricional na América Latina e até no mundo.

Malaquias Batista Filho 


\section{Introdução}

Nos últimos vinte anos, diferentes organismos internacionais vêm preconizando, particularmente para os paises não-desenvolvidos, a implantação de sistemas de vigilância alimentar e nutricional (SISVAN), apontando-os como um instrumento capaz de subsidiar e avaliar políticas e programas de diversos setores governamentais ${ }^{61,63,102,157}$. Para tal, estes sistemas deveriam ser multisetoriais, abarcando e articulando informações da agricultura, economia, planejamento, educação e saúde, cabendo a este último setor a produção de dados sobre estado nutricional da população ${ }^{5,8}$.

Concretamente, no entanto, o SISVAN tem apresentado inúmeras limitações operacionais em vários dos países que o implantaram, mantendo-se, na maioria deles, restrito ao setor saúde, dirigido principalmente a crianças menores de cinco anos ${ }^{10,17,154}$. Ainda assim, os documentos e autores que debatem a relação entre aquele sistema e este setor costumam deter-se na discussão sobre quais dados e indicadores - diretos e indiretos - de estado nutricional deverão ser produzidos, com vistas à estruturação de um sistema intersetorial ${ }^{5,102,154}$.

Não tem havido, portanto, historicamente, uma preocupação em se abordar de que forma este setor poderia utilizar as informações por ele mesmo produzidas para o planejamento e avaliação de suas próprias políticas e intervenções e, em especial, para a redefinição e conseqüente melhoria da assistência prestada. Ou seja, embora se tenha claro o papel do setor saúde no SISVAN (produzir dados sobre estado nutricional), pouco se tem refletido (ou, pelo menos, registrado) sobre o papel do SISVAN no setor saúde, particularmente na rede pública de assistência.

Publicações mais recentes, que procuram articular o SISVAN com a rede de saúde, 0 fazem de maneira ainda um tanto geral, como uma primeira aproximação, sem uma discussão de maior fôlego sobre as possibilidades e limitações desta articulação, e sem lapidar desdobramentos operacionais mais detalhados ${ }^{10,11,17,62}$. A despeito desta discussão, vem crescendo, no Brasil, o número de estados e municipios que estão implantando o sis$\mathrm{VAN}^{17}$, em geral vinculado às secretarias de saúde.

A convivência diária com esta implantação tem sugerido que a mencionada articulação entre SISVAN e rede de saúde não é nada trivial. Ao contrário, parece existir uma distância entre a proposta de SISVAN, tal como está formulada por organismos como OMS, OPS, FAO, UNICEF e INAN, e a lógica que orienta a prática dos profissionais nesta rede de 
assistência, fazendo daquele sistema um instrumento limitado para a formulação, implementação e avaliação de respostas desta rede aos agravos nutricionais da população.

Entre os aspectos que explicitam a distância acima mencionada, podem ser apontados os seguintes:

1. para o sISVAN, proposto como um sistema intersetorial, o que interessa são informações agregadas, com o propósito de subsidiar políticas governamentais, cabendo ao setor saúde fornecer dados sobre o perfil nutricional. Para a rede de saúde, particularmente no nivel local, as informações coletivas só têm sentido se subsidiam e redimensionam o atendimento individual, carro-chefe da prática de assistência;

2. o SISVAN vem sendo tradicionalmente proposto como um sistema de informações estrito (não lhe sendo atribuidas atividades de intervenção), entendendo-se como papel da rede de saúde, para fins deste sistema, apenas a produção de informações sobre estado nutricional ${ }^{102}$. Na rede de saúde, por sua vez, qualquer sistema de informações só tem sentido se for intimamente vinculado às intervenções viáveis e condizentes com a sua (da rede) estrutura. Até porque, principalmente no nivel local, os que geram e consolidam dados são os mesmos que prestam assistência, sendo, portanto, irreal e ilógico pensar nestas duas práticas de maneira desarticulada; e

3. nos últimos anos, as publicações que discutem ou fazem referência ao processo de determinação do perfil nutricional - entre elas as que sistematizam a proposta de SISVAN e as que refletem sobre a prática no setor saúde frente àquele perfil - parecem apontar para um consenso sobre a complexa rede de determinantes do mesmo: estrutura econômica do país; distribuição de renda; poder aquisitivo da família; condições de vida e moradia; produção, acesso, consumo e utilização biológica dos alimentos; acesso aos serviços de saúde, entre outros ${ }^{8,18,22,24,105,196}$.

Embora tanto para o sISVAN como para a rede de saúde esta formulação sobre o processo de determinação do perfil nutricional seja um marco referencial, no SISVAN é enfatizada, historicamente, a relação entre estado nutricional e produção e consumo de alimentos ${ }^{63,102,154}$, determinantes que extrapolam a capacidade de intervenção da rede de assistência. Sob a perspectiva da rede, no entanto, tem sido valorizada a relação entre perfil nutricional e utilização biológica dos alimentos, enfoque que possibilita ações mais apropriadas aos serviços de saúde ${ }^{16,57}$.

A partir dos elementos comentados acima, fica explicitada a necessidade de serem repensadas as possibilidades e limitações do sISvAN na rede pública de assistência à saúde, à luz tanto da prática nela já vivenciada quanto do seu papel frente aos agravos nutricionais da população. Esta necessidade se justifica, também, pela atualidade do assunto ${ }^{62}$ e por ser ainda escassa a produção acadêmica brasileira sobre o mesmo.

É este, portanto, o tema central deste livro: analisar e repensar a proposta de sIsVAN, tendo como núcleo a reflexão sobre suas possibilidades e limitações como instrumento de resposta institucional da rede pública de saúde aos agravos nutricionais da população brasileira. 
Para o desenvolvimento do mesmo, são assumidas as seguintes premissas:

1. o estado nutricional é um elemento fundamental do processo saúde-doença. Portanto, quaisquer inadequaçōes - sejam subnutrição, obesidade ou carências especificas como as de ferro ou vitamina A - guardam estreita relação com a ocorrência ou agravamento de doenças e vice-versa;

2. o setor saúde tem o papel de dar resposta, em diferentes níveis e de maneira resolutiva, aos agravos da população. Para tal, é fundamental conhecer o perfil de morbimortalidade da população e, com base nisto, planejar ações diversas, entre elas, a reorganização da rede pública de assistência, $e$

3. pensar em respostas resolutivas da rede pública de assistência aos agravos nutricionais da população brasileira implica pensar ações que respondam de maneira integra$d a$ aos perfis nutricional e de morbimortalidade da mesma.

Por fornecerem subsídios interessantes para a reflexão proposta, os seguintes temas lhe servem de pilares: (a) o perfil de saúde e nutrição da população brasileira; (b) o histórico e as caracteristicas teóricas e operacionais do SISvAN e (c) o histórico e as caracteristicas teóricas e operacionais das práticas de vigilância epidemiológica e de atenção integral à saúde, desenvolvidas na rede pública de assistência.

O desenrolar do tema proposto se dá através do seguinte trajeto reflexivo: inicialmente, situa-se historicamente o surgimento da proposta de SISVAN em âmbito internacional e sistematiza-se sua evolução, particularmente nos paises não-desenvolvidos, para, em seguida, ser articulada a história desta proposta no Brasil com as políticas sociais de alimentação e nutrição implementadas nas duas últimas décadas (Capítulo1). Depois, é comentada a situação atual de saúde e nutrição da população brasileira (Capítulo 2), bem como sistematizadas as práticas de vigilância epidemiológica e aquelas contempladas em programas de atenção integral, hoje em andamento na rede de saúde (Capitulo 3). Reunindo-se os elementos registrados ao longo deste percurso, discute-se o papel da rede de saúde - e do SISVAN como seu instrumento - em relação ao perfil de saúde e nutrição da população brasileira, cotejando-se, depois, a proposta de sISVAN com as práticas de vigilância epidemiológica e de atenção integral, delineando-se possiveis interações e diferenças (Capitulo 4). 


\section{CAPÍTULO 1}

\section{SISVAN: antecedentes}

Neste capítulo, será comentado o contexto histórico da proposição de Sistema de Vigilância Alimentar e Nutricional (SISVAN); discutido seu conteúdo inicial, sua evolução ao longo dos anos e sua situação atual, particularmente na América Latina. Serão apresentados alguns modelos de determinação do estado nutricional adotados na sua fundamentação; comentada a relação deste sistema com a Segurança Alimentar e, por fim, relatada a história de sua implantação no Brasil.

\section{Formalização da proposta}

Para uma melhor compreensão do contexto do surgimento da proposta de SISVAN, formalizada em 1974, quatro elementos merecem ser brevemente comentados.

O primeiro diz respeito ao estado da arte do conhecimento acadêmico na área de alimentação e nutrição. Entre 1915 e 1935, foram criados, em diversos países, centros e comissões de pesquisa ligados ao campo da alimentação e nutrição, direcionados para a definição das necessidades alimentares do ser humano, o estudo dos recursos disponíveis para satisfazê-las e a colocação destes ao alcance daquelas necessidades ${ }^{96}$.

No entanto, até as décadas de 50 e 60 , muito do que se afirmava sobre os perfis alimentar e nutricional das populações não tinha respaldo cientifico. Neste periodo, estudos bastante extensos e complexos foram realizados e apontaram a gravidade do quadro de deficiências alimentares e nutricionais das populações de paises subdesenvolvi$\operatorname{dos}^{17,19,154}$, havendo, inclusive, jả nesta época, indicações de um potencial agravamento desta situação ${ }^{8}$.

Em fins dos anos 60 e inicio dos 70, foram sendo evidenciadas importantes limitações destas pesquisas, ligadas ao seu alto custo e ao longo tempo de realização, fazendo com que os resultados só fossem divulgados alguns anos após o estudo e, ainda assim, sem uma análise mais profunda dos dados.

Na verdade, estes estudos não conseguiram dar respostas suficientes, seja em relação aos fatores que originavam os agravos nutricionais ou aos desdobramentos no campo de ações preventivas ${ }^{24}$.

A partir de então, tomou corpo um novo enfoque, mais pragmático, que buscava 
conhecer o perfil nutricional das populações, suas tendências e seus determinantes através de procedimentos menos minuciosos, porém mais rápidos e baratos ${ }^{24}$. Foi justamente este enfoque que se fez presente na proposta de SISVAN.

O segundo aspecto a ser comentado se refere ao investimento, pelos govemos de então, na planificação multisetorial como estratégia para a construção do desenvolvimento socioeconômico.

Depois da II Guerra Mundial, o desenvolvimento econômico era entendido como sendo equivalente ao crescimento do Produto Interno Bruto (PIB), acreditando-se que um investimento intensivo em capital e tecnologia levaria os países subdesenvolvidos a caminharem para um crescimento auto-sustentado ${ }^{23}$.

No entanto, diante do real aumento do número de desempregados, analfabetos e desnutridos nestes países, começou-se a falar em desenvolvimento socioeconômico e desenvolvimento com redistribuição ${ }^{23}$. Foi-se lapidando a idéia de que o desenvolvimento econômico não poderia ficar à mercê das leis de mercado, sendo necessário racionalizá-lo através do planejamento ${ }^{171}$. Este, por sua vez, deveria envolver o crescimento econômico e, também, as necessidades humanas básicas, valorizando-se a eqüidade social ${ }^{102,106}$. Perpassaria, portanto, os vários setores das politicas governamentais, incluindo-se as de alimentação e nutrição ${ }^{102,103}$, cuja meta seria a erradicação da desnutrição ${ }^{158}$.

$\mathrm{O}$ terceiro tema a ser comentado trata das situaçōes econômica e de produção de alimentos naquele periodo. Em fins da década de 60 e inicio da de 70, um número expressivo de paises não-desenvolvidos viveu um periodo de otimismo em relação ao seu crescimento econômico, com boas taxas de crescimento do produto real e aumento da exportação dos seus produtos.

A mudança deste quadro de expansão não foi repentina. Entre os fatores que a desencadearam figuram a crise monetária internacional, iniciada com a desvalorização do dólar em 1971 e, fundamentalmente, a quadruplicação dos preços do petróleo, em outubro de 1973. A partir de 1974, aprofundou-se a crise na economia mundial, criando-se uma grave situação nas regiōes mais pobres, para as quais foi transferido o ônus do aumento dos custos do petróleo, através do endividamento externo, da queda dos preços dos produtos por elas exportados e do aumento dos preços daqueles importados ${ }^{138}$.

$O$ desdobramento disto, nos anos seguintes, foi, por parte de muitos países não-desenvolvidos, o engajamento em um processo de adaptação da economia, através de políticas de ajuste econômico, marcadas por elevação da inflação, recessão com desemprego e empobrecimento dos assalariados, pequenos empresários, aposentados e pensionistas, entre outros ${ }^{35,138}$. Para "aliviar" o ônus pago por esta parcela da população, inúmeros governos lançaram mão de uma série de politicas sociais compensatórias ${ }^{138}$.

O quarto tema a ser citado diz respeito à enorme escassez mundial de cereais e ao aumento exorbitante dos preços de trigo e arroz, ocorrida concomitantemente aos acontecimentos anteriores, no periodo de 1972 a 1974, tudo isto conduzindo a uma profunda crise alimentar mundial ${ }^{8,179}$.

Foi neste contexto que surgiu e tomou corpo a proposta de sisvaN. Na Conferência Mundial de Alimentação (Roma, 1974), foi formalizada a proposta de vigilância nutricional, fazendo-se uma transposição do conceito de vigilância das enfermidades, largamente 
aceito à época. Esta proposta ampliou uma idéia que havia sido pensada em relação ao socorro em caso de seca e tomou emprestado uma experiência já iniciada nos Estados Unidos da América ${ }^{63,154,157,178}$. Ainda neste fórum, ficou definido que esta proposta seria operacionalizada através de um sistema de vigilância, a ser estabelecido pela FAO, OMS e UNICEF,

"(...) para monitorizar as condições dos grupos desfavorecidos da população a risco, e para proporcionar um método de avaliação rápida e permanente de todos os fatores que influenciam os padrões de consumo alimentar e o estado nutricional." (FAO/OMs, 1974, resoluçâo V.13).

Como desdobramento, um comitê de especialistas da FAO, UNICEF e OMS elaborou um relatório que deveria fornecer instruções sobre a natureza de um sistema de vigilância nutricional, sua estruturação e os princípios para sua operacionalização. Este documento sistematizou a proposta formulada na Conferência, procurando dar-lhe contornos operacionais factiveis ${ }^{63}$.

Nele, embora se afirmasse que um sistema de vigilância nutricional pudesse ser necessário em qualquer pais, assumiu-se como tema central a vigilância de agravos nutricionais em paises não-desenvolvidos, para os quais ela foi vista como sendo de grande urgência. Isto porque, nestes, a of erta de alimentos e o estado nutricional de grupos vulneráveis eram muitas vezes marginais, a desnutrição podia ser endêmica e variações não usuais de fatores ambientais podiam levar a desnutrição a alcançar proporções epidêmicas.

Tendo estes argumentos como pano de fundo, o sisvan foi apresentado como um sistema intersetorial de coleta, processamento e análise de informações, que teria como objetivo geral promover

"(...) informação contínua sobre as condições nutricionais da população e os fatores que as influenciam. Esta informação irá fornecer uma base para decisões a serem tomadas pelos responsáveis por politicas, planejamento e gerenciamento de programas relacionados com a melhoria dos padrões de consumo alimentar e do estado nutricional." (FAO/UNICEF/WHO, 1976, p. 8)

E, como objetivos específicos,

"1. Descrever o estado nutricional da população, com particular referência a subgrupos definidos que são identificados como estando sob risco. Isto permitirá a descrição do caráter e magnitude do problema nutricional e mudanças nestas características.

2. Prover informação que irá contribuir para a análise das causas e fatores associados e, então, permitir uma seleção de medidas preventivas, que poderão ser ou não nutricionais.

3. Promover decisões por parte dos governos relativas a prioridades e disponibilidade (uso) de recursos para satisfazer as necessidades tanto do desenvolvimento normal quanto de emergências. 
4. Permitir predições a serem feitas com base nas tendências atuais a fim de indicar a evolução provável dos problemas nutricionais. Consideradas em associação com as medidas e recursos existentes e potenciais, estas irão ajudar na formulação de políticas.

5. Monitorar programas nutricionais e avaliar sua efetividade"

(FAO/UNICEF/WHO, 1976, p. 9)*.

Portanto, o sisvan foi pensado para servir, ao mesmo tempo, como um sistema que avisasse precocemente possiveis desastres nutricionais e como um método de monitoramento de tendências numa situação de privação crônica, subsidiando o planejamento multisetorial. Para tal, seria imprescindivel que estivesse estreitamente vinculado a organismos responsáveis pela execução de politicas e gerasse informações oportunas ${ }^{63,102}$.

\section{Evolução do SISVAN}

Ainda na década de 70 , cerca de 20 países em todo o mundo já iniciavam a implantação do sisvaN ${ }^{102}$. Nos anos 80 , este número cresceu e, atualmente, só na América Latina e Caribe, os seguintes paises estão envolvidos com esta proposta: Bolívia, Brasil, Chile, Colômbia, Costa Rica, Cuba, El Salvador, Equador, Guatemala, Guiana, Honduras, México, Nicarágua, Panamá, Peru, República Dominicana, Uruguai e Venezuela ${ }^{64,106}$. A maioria destes tem como grupo alvo as crianças até cinco anos e, em menor escala, as gestantes, escolares e adultos ${ }^{102,106,154,207}$.

Em linhas gerais, os diversos sistemas existentes produzem informações sobre uma ou mais das seguintes áreas: estado nutricional e estado de saúde da população; fornecimento de alimentos e sua composição e padrões de consumo, conhecimento e atitudes alimentares ${ }^{207}$. $a^{106,154:}$

Há uma série de diferenças entre estas experiências em relação, por exemplo,

1. quais setores governamentais são responsáveis pela viabilização do SISVAN, possibilitando ou não sua dimensão intersetorial. Na maioria dos paises, somente o Ministério da Saúde está envolvido, havendo, em alguns, a participação dos Ministérios da Agricultura, Educação, Economia e Bem-Estar Social;

2. a articulação dos diversos niveis dentro de cada setor;

3. a cobertura da população alvo;

4. quais indices, populações de referência e pontos de corte são utilizados, dificultando comparações entre paises. Por exemplo, para o grupo de crianças menores de cinco anos, há os que empregam massa corporal para idade, outros, massa corporal para es- 
tatura; uns utilizam referências nacionais, outros, a sugerida pela oMs; alguns lançam mão do Critério de Classificação de Gòmez ${ }^{75}$, outros, percentis 10 e/ou 3, outros ainda, menos 2 desvios-padrão.

Inicialmente, a vigilância alimentar e nutricional foi pensada numa perspectiva "(...) unicista, na medida em que se propõe a reunir elementos para a definição de politicas e instrumentação de programas de ação cujo objetivo final seria a obtenção de padrões adequados de alimentação e nutrição da coletividade" (Batista Filho \& Rissin, 1993, p. 100).

No entanto, nas experiências dos paises não-desenvolvidos, foram delineadas atividades de vigilância nutricional com fins diferentes, de acordo com a realidade de cada um e com a vontade política de seus governantes. Estes fins não se excluem e, em alguns países, acontecem de maneira integrada.

Podem ser organizados em três grupos: vigilância nutricional para planejamento da saúde e do desenvolvimento socioeconômico; avaliação da adequação de programas (comumente de suplementação alimentar), empregando-se métodos de vigilância nutricional; e programas de alarme oportuno e intervenção, em paises que apresentem flutuações rápidas na produção e fornecimento de alimentos devido a fatores sazonais, como por exemplo a seca ${ }^{102}$.

Mais recentemente, estes 'tipos' de SISVAN foram apresentados como "componentes com identidade própria”, sendo agrupados de uma maneira um pouco diferente: vigilância da segurança alimentar, ligada à definição de politicas econômicas e sociais; sistema de alerta rápido, com o papel de registrar ou prever crises alimentares agudas sejam por motivos climáticos ou politicos, e.g., guerras; vigilância do crescimento de crianças, vinculado ao serviços de saúde e mais difundido; e vigilância das medidas de ajuste econômico ${ }^{17}$.

Confere-se, ainda, ao SISVAH, o papel de instrumento de advocacia, por parte de técnicos, outras instâncias governamentais ou mesmo da sociedade civil, junto aos organismos decisores a partir das informações produzidas ${ }^{158}$.

Nos paises de primeiro mundo, o sISVAN assumiu um contorno diferente, sendo caracterizado, na Europa, por dois subsistemas: a vigilância dietética, que avalia os hábitos alimentares da população, e a vigilância do impacto da nutrição na saúde, especificamente nas doenças cardiovasculares, infertilidade por excesso de aditivos nos alimentos, entre outros agravos à saúde ${ }^{93}$.

Nos Estados Unidos da América, este sistema comporta os dois perfis descritos acima. Inicialmente dirigido, ainda na década de 70, para o grupo materno-infantil de baixa renda contemplado no Programa Especial de Suplementação Alimentar, expandiu-se, mais recentemente, envolvendo vários ministérios ${ }^{178,192,207}$.

Hoje abarca adultos, acompanhando fatores de risco para doenças crônicas relacionados com a alimentação, e adolescentes, acompanhando também os hábitos relacionados com a alimentação, através de dados de escolares ${ }^{192}$.

Particularmente nos paises não-desenvolvidos, o avanço do SISVAN se deu em duas direções. A primeira foi o investimento no aperfeiçoamento técnico dos instrumentos, lapidando-se um SISVAN referenciado no marco do planejamento nutricional, composto pe- 
los subsistemas de disponibilidade, acesso, consumo e nutrição. A segunda foi a busca de soluções para a debilidade do componente alimentar no SISVAN e a distância entre este e os niveis de decisão ${ }^{158}$.

Esta evolução do SISVAN, especialmente nos paises não-desenvolvidos, foi marcada por uma série de decisões e tendências internacionais ocorridas nos últimos vinte anos, entre elas:

\begin{abstract}
"(...) a ênfase dada à atenção primária à saúde (...); o conceito de integração das necessidades básicas (...); a idéia de que as políticas de planejamento e desenvolvimento econômicos devem levar em consideração as questões de nutrição (...) e a tendência crescente de se empregarem os indicadores nutricionais para medir qualidade de vida, em particular como meio de avaliar tanto os programas de desenvolvimento como os de saúde" (Mason et al., 1984, p. 16).
\end{abstract}

Estas decisões e tendências têm se explicitado, ao longo dos anos, através de documentos e eventos internacionais, como por exemplo: a Conferência de Alma-Ata, em $1978^{205}$; a Conferência Mundial sobre Reforma Agrária e Desenvolvimento Rural, em $1979^{62}$; a proposta de uma Revolução pela Sobrevivência e Desenvolvimento da Criança, patrocinada pelo UNICEF, em 1983 ${ }^{17}$; a Conferência de Cúpula de Nova Iorque, em $1990^{16,194}$ e a Conferência Internacional sobre Nutrição, em $1992^{62}$.

Os dois últimos eventos merecem, por seu teor e atualidade, maiores comentários. $\mathrm{Na}$ Conferência de Cúpula de Nova Iorque, firmou-se o compromisso internacional de se alcançarem, até o ano 2000, em todos os paises do mundo, metas específicas de nutrição, entre elas:

“(...) - a redução à metade do nivel do ano de 1990 da desnutrição energético-protéica moderada e grave nas crianças menores de cinco anos;

- a redução a menos de $10 \%$ da proporção de crianças nascidas com baixo peso (menos de $2,5 \mathrm{~kg}$ ) (...);

- a redução em 1/3 do nivel do ano de 1990 da anemia ferropriva (...) entre as mulheres em idade fértil;

- A eliminação quase total das doenças causadas pela falta de iodo (...);

- A eliminação quase total da carência de vitamina $A$ e suas conseqüências, incluindo a cegueira" (UNICEF, 1990, p. 15).

Para que estas metas fossem alcançadas apontou-se como um dos componentes estratégicos a estruturação e/ou aperfeiçoamento de sistemas de informação em nutrição. Reforçou-se, também, a importância de os programas nutricionais estarem articulados com as práticas de atenção primária à saúde, baseando-se nas experiências que obtiveram sucesso na década de 80 , nas quais esta articulação foi garantida.

Tradução da autora. 
$\mathrm{Na}$ Conferência Internacional de Nutrição, assumindo "o valor intrínseco da vida humana e da dignidade que leva consigo" (FAO/OMS, 1992, p. 5) foi reconhecido que

"(...) o acesso a uma alimentação nutricionalmente adequada e saudável é um direito de cada pessoa" e que "(...) globalmente existem suficientes alimentos para todos; o problema principal é o de um acesso desigual a estes alimentos" (FAO/OMS, 1992, p. 1),

firmando-se o compromisso de se fazer todo o possível para eliminar, antes do final desta década:

"(...) - a fome e as mortes por fome;

- a inanição e as enfermidades por carências nutricionais em comunidades

afetadas por catástrofes tanto naturais como causadas pelo homem;

- as carências de iodo e vitamina A" (FAO/OMS, 1992, p. 5).

e reduzir consideravelmente, durante esta década:

"(...) - a inanição e a fome crônica generalizada;

- a desnutrição, especialmente entre as crianças, mulheres e anciãos;

- outras importantes carências de micronutrientes, incluindo o ferro;

- as enfermidades transmissiveis e não-transmissiveis relacionadas com a alimentação;

- os impedimentos sociais e de outra indole a uma lactância materna ótima;

- as condições inadequadas de saneamento e de uma higiene deficiente, incluindo o uso de água potável" (FAO/OMS, 1992, p. 5).

Para que estes compromissos se viabilizassem, foi formulado um plano de ação, no qual estão previstas, através do SISVAN, atividades de avaliação e acompanhamento de situações nutricionais ${ }^{62,194}$.

O relato destes eventos sugere uma perspectiva otimista para a aplicabilidade e legitimação do SISVAN. No entanto, a história da sua implantação nos diversos paises revela sérias limitações em dar conta do seu objetivo fundamental, qual seja o de gerar informações oportunas, que subsidiem $e$ avaliem políticas e intervenções.

Embora tenha se desenvolvido de forma satisfatória em termos técnicos, as informações geradas por ele não têm influenciado as decisões políticas dos governos. Isto porque, comumente, este sistema é viabilizado de forma paralela, por grupos técnicos de nutrição vinculados ao setor saúde, não havendo, a priori, uma demanda real das informações a serem geradas ${ }^{10,17,154,201}$.

Como cita ORALC/FAO (sd, p. 2):

" (...) é legítima a frustração dos técnicos, empenhados em operar estes sistemas com grandes dificuldades técnicas e falta de recursos, ao ver seus informes engavetados nos despachos superiores. Junto com os especialistas 
que os assessoram, buscam com obstinação sistemas mais manejáveis (por exemplo o estabelecimento de centros sentinelas), instrumentos mais práticos para medição de indicadores (gráfico de Navarro), indicadores mais sensíveis (altura de escolares) ou mais elásticos (baixo peso ao nascer), com a esperança de que, com um melhor serviço e uma maior qualidade do produto, terminem ganhando a atenção dos que têm a última palavra, os decisores. Mas, apesar dos progressos técnicos, a penetração nos niveis de decisão tem sido pobre".

Segundo Mock e Bertrand (1993), três grupos de fatores intervêm no processo de tomada de decisões no campo social: os relacionados com a responsabilidade dos que tomam as decisōes (forças politicas, valores sociais, organização, legislação, meios de comunicação), as caracterisitcas de controle de recursos (e.g. descentralização) e as caracteristicas da informação (conteúdo, apresentação e oportunidade).

Fica claro, portanto, que o papel do sISVAN - subsidiar os poderes públicos na formulação e avaliação de suas políticas - só é viável se houver interesse govemamental para tal. Não se pode esperar que este sistema, por melhor que seja planejado e operacionalizado, contribua para a melhoria do perfil nutricional da população a médio e longo prazos se, no pais, as politicas economica e social caminharem distantes desta perspectiva ${ }^{23,102}$.

No entanto, antes de se atribuir a responsabilidade desta pouca utilidade do SISVAN exclusivamente à falta de vontade politica dos governantes, é interessante comentar alguns aspectos comumente presentes na estruturação deste sistema, ao menos na América Latina, que têm também papel decisivo nesta pouca legitimidade do SISVAN. São eles ${ }^{10,106,154,158}$ :

1. criação de estruturas técnico-administrativas paralelas, exclusivas para o SISVAN, dificultando a integração entre esta proposta e as organizações já existentes;

2. formulação de modelos muito complexos, de operacionalização inviável;

3. vinculação excessiva a financiamentos externos, sem serem garantidos recursos próprios para o sistema;

4. ausência de interligação, dentro do setor saúde, com a vigilância epidemiológica, embora, quando do seu surgimento, tenha nela se inspirado;

5. evolução maior no campo dos dados antropométricos que nos de alimentação, sabendo-se mais sobre as conseqüências do que sobre o processo de determinação dos agravos nutricionais;

6. informações geradas não conseguirem ser oportunas, seja porque os consolidados e análises demoram a ser produzidos, porque as informações são muito gerais ou, ainda, porque não são entendidas ou de interesse dos usuários potenciais. Este último aspecto se dá pelo fato de os técnicos, desconectados do âmbito das decisões, e ignorando, comumente, sua realidade e complexidade, decidirem quais são as informações mais relevantes para os potenciais usuários (governantes), sem consultá-los. Na verdade, a frágil relação informação/decisão reflete a distância técnico/decisor; 
7. o sistema ainda se encontrar muito centralizado no nivel federal, não conseguindo colat-se às realidades locais;

8. haver a supervalorização das estatísticas em detrimento do investimento em ações;

9. por ter se concentrado tanto em melhorias técnicas, a vigilância se tornou um campo de aplicação de instrumentais de informação, isolando-se como uma especialidade à parte, com finalidade própria.

\section{Determinantes do perfil nutricional}

Nos textos que fundamentam e discutem a operacionalização do SISVAN, está sempre presente, de maneira subjacente ou explícita, a idéia de que o processo de determinação do perfil nutricional da população é multicausal, sendo influenciado por inúmeros fatores $5,16,23,63$.

Dai a necessidade de o SISVAN ser intersetorial, manuseando indicadores de diferentes áreas, dando suporte informativo para o modelo de planejamento multisetorial, comentado anteriormente $8,10,102,154$, apostando-se na sua capacidade de monitoramento e avaliação de impacto ${ }^{158}$.

É importante deixar claro que não se espera do SISVAN a elucidação ou comprovação de relações de causa e efeito, tarefa que cabe à pesquisa científica ${ }^{102}$. Seu papel é acompanhar indicadores que sintetizem os diversos fatores envolvidos na determinação do perfil nutricional da população.

Os modelos adotados para a análise deste processo de determinação comumente aparecem nas entrelinhas ${ }^{20}$ ou são citados na fundamentação do SISVAN, através da menção de "situações ou fatores condicionantes"14,22,77,99,139,196, ou da chamada "cadeia alimentar" 7,77 ou, ainda, através de esquemas explicativos - diagramas da própria "cadeia alimentar"93 ou, finalmente, mais amplos, denominados "marco conceitual" 106 ou "modelo causal"16,18,102. Este último é definido como um esquema que ordena, de forma explicita, hierarquizada e simplificada, o complexo processo de determinação do estado nutricional de um grupo ou população ${ }^{21}$.

Além de ser citado na fundamentação, alguns autores sugerem a construção do modelo causal como etapa preliminar à implantação do SISVAN. Ela seria um componente da avaliação inicial da situação do país, região, município ou comunidade, formecendo maior instrumental para a escolha dos indicadores a serem utilizados na rotina do siste$\mathrm{ma}^{15,17,23,24,63,106,195}$.

Embora a multicausalidade seja consenso no discurso dos mais diversos autores e organismos internacionais, a forma de enfocá-la apresenta nuances que merecem ser discutidas. Apesar de óbvio, vale comentar que, na tentativa de se explicar a determinação do perfil nutricional, as diferentes formas de se recortar a realidade poderão influenciar, entre outros, a escolha dos indicadores e, portanto, a definição dos contornos que o sisVAN venha assumir.

Com o amadurecimento da proposta de SISVAN e a evolução da rede pública de as- 
sistência à saúde nos paises não-desenvolvidos, foram se configurando, neste modelo, duas grandes vertentes de determinação do perfil nutricional. Uma, relativa ao consumo de alimentos, que envolve, entre outros, fatores como as políticas econômica e agrícola, poder aquisitivo, hábitos e distribuição intrafamiliar de alimentos. Outra, referente à utilização biológica dos alimentos, que abarca, entre outros, fatores como condições de moradia, acesso a serviços de saúde e ocorrência de agravos infecciosos ou não ${ }^{16,21,23,24}$.

Tomando o modelo causal como instrumento norteador da estruturação do sISVAN, chama atenção o fato de, no primeiro esquema associado formalmente ao sisvaN ${ }^{63}$, a vertente de utilização biológica dos alimentos praticamente inexistir, sendo representada apenas pelo fator "infecção" (Figura 1).

Por este esquema, então, o SISVAN deveria estar fundamentalmente estruturado nos setores de agricultura e economia, que dariam conta de acompanhar indicadores relativos ao eixo de consumo alimentar. No entanto, à revelia desta análise, foi justamente o setor saúde que tradicionalmente implantou o SiSVAN na maioria dos paises.

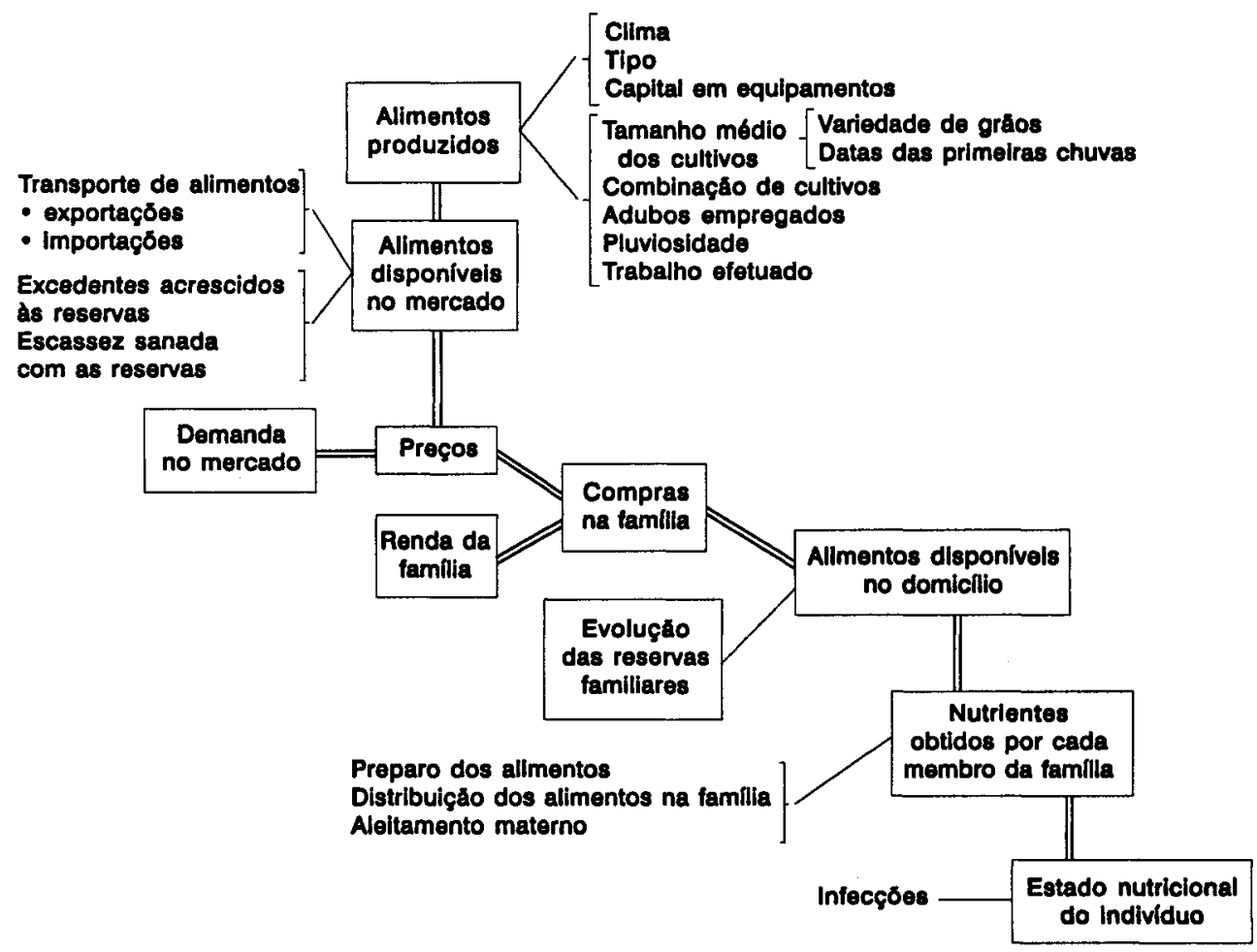

Figura 1 - Diagrama ou modelo como uma hipótese de trabalho.

Fonte: FAO/UNICEF/WHO (1976). 
Ainda em fins da década de 70 , já circulavam propostas de modelo nas quais a vertente de utilização biológica se apresentava mais desenvolvida, inclusive apontando-se a atenção à saúde como um dos seus determinantes ${ }^{23}$. No entanto, documentos sobre o sisVAN, publicados pela OMS e OPS em meados e fins da década de $80^{102,154}$, embora baseados na experiência de países onde o setor saúde tinha participação fundamental ou exclusiva na execução deste sistema, ainda mantiveram bastante restrita a vertente em questão (Figura 2).

Alguns autores, entretanto, neste mesmo periodo, já apresentaram este eixo mais estruturado (exemplo na Figura 3), dando subsidios para a escolha de indicadores do setor saúde para o acompanhamento dos determinantes do estado nutricional ${ }^{18,24}$. Recentemente, tem sido enfatizada, nos debates sobre as possibilidades de atuação do setor saúde frente à questão nutricional, a atenção a esta segunda vertente, argumentando-se que é nela que o setor saúde tem mais condições de intervir ${ }^{16}$.
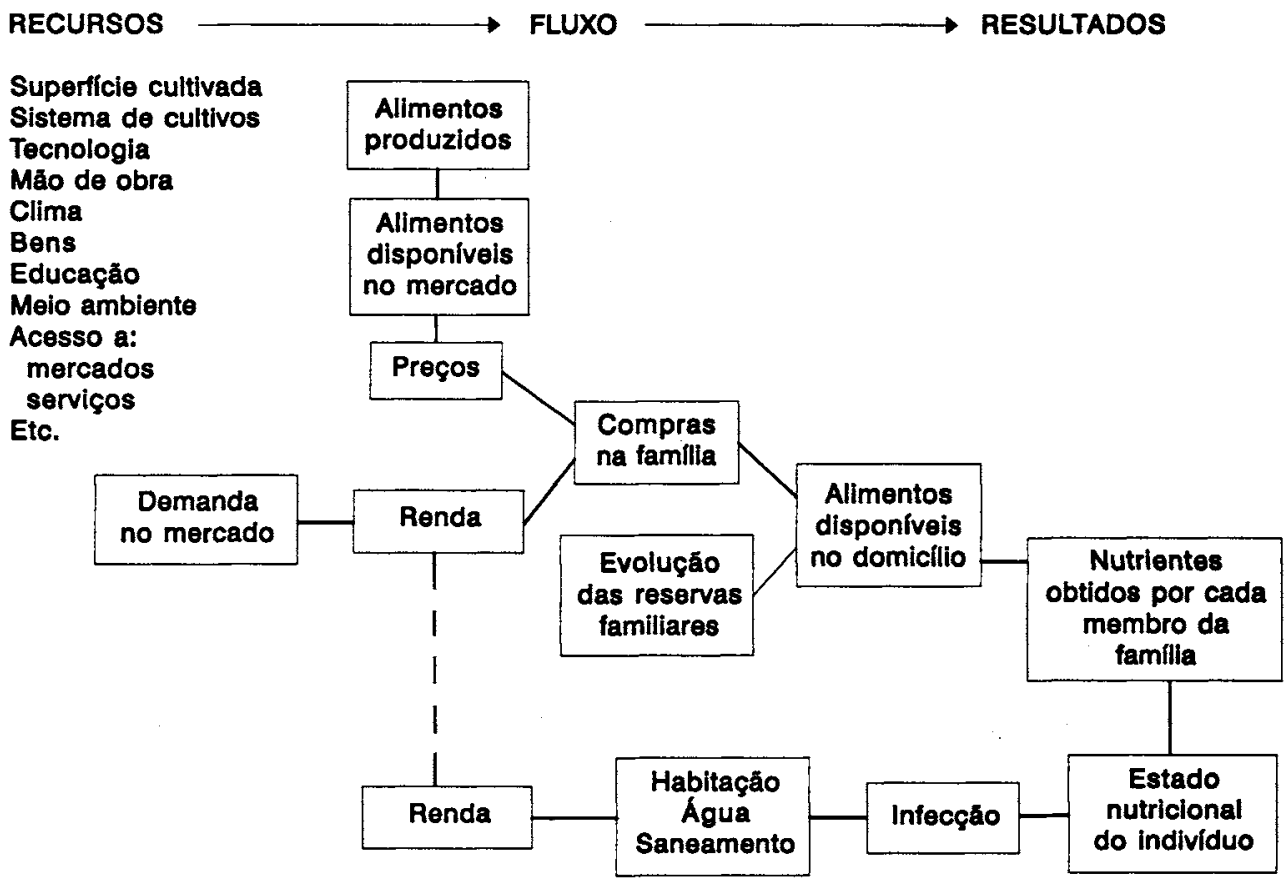

ÂMBITO NACIONAL / COMUNIDADE

Figura 2 - Relação entre as variáveis de recursos e fluxos e os resultados nutricionais.

Fonte: Mason, Habicht, Tabatabai \& Valverde (1984). 


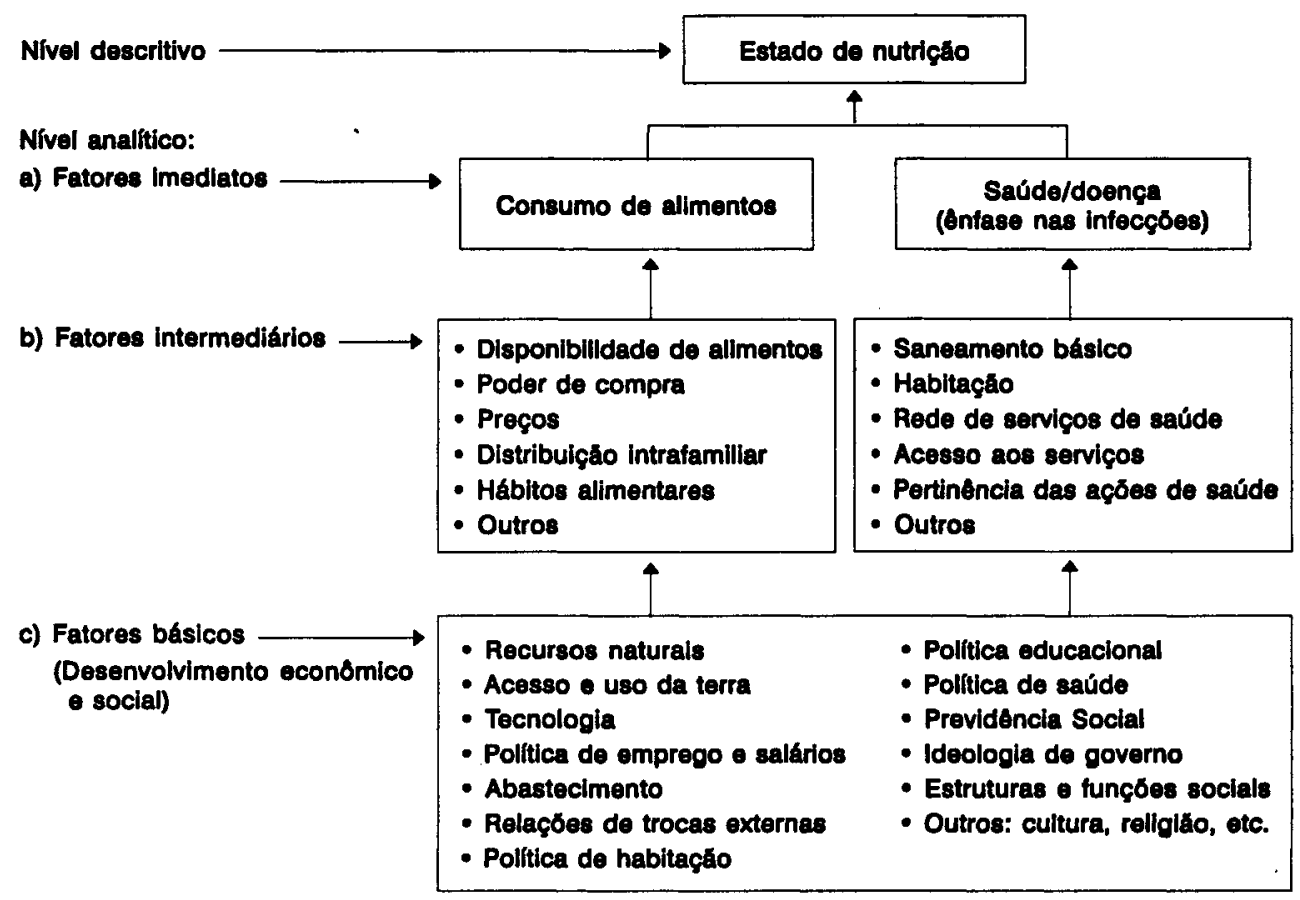

Figura 3 - Esquema ilustrando possiveis relações hierárquicas do modelo causal.

Fonte: Batista Filho \& Shiraiwa (1989).

Atualmente, dirigindo-se este modelo para a desnutrição em crianças, incorporouse mais uma vertente, o cuidado infantil, que seria o dispêndio de tempo e de atenção para atender às necessidades da criança ${ }^{194}$ (Figura 4). Caracterizar os elementos que compõem este determinante como uma vertente em si é, sem dúvida, um avanço na compreensão do processo de derminação da desnutrição neste grupo específico, uma vez que valoriza uma dimensão da vida cotidiana que é crucial para a sobrevivência e crescimento infantil adequado.

\section{O SISVAN e a Segurança Alimentar}

A principio, pode parecer curioso que, entre os elementos que compuseram o contexto de surgimento da proposta de SISVAN, não tenha sido citado, no inicio do capítulo, o conceito de Segurança Alimentar (SA), uma vez que este também foi inicialmente proposto no início da década de 70, quando da crise mundial de produção de alimentos ${ }^{158}$.

Esta não inclusão e a opção de se discutir este tema em um item próprio foram devidas à constatação de que este marco referencial, embora apresente uma interface interessante com o SISVAN, não foi mencionado nem se fez presente, mesmo que de forma 


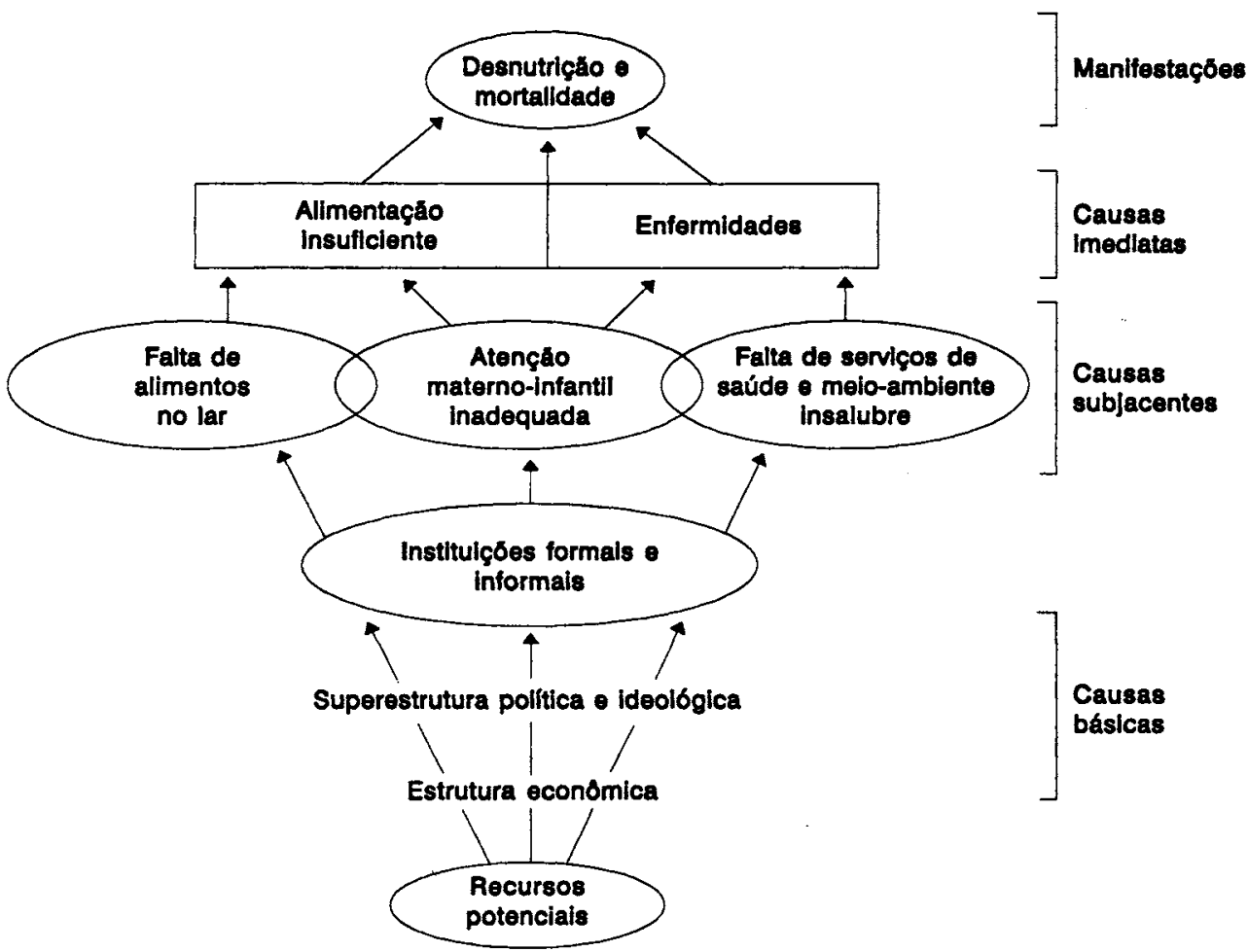

Figura 4 - Causas da desnutrição e mortalidade

Fonte: UNICEF (1990).

não explícita, nos documentos de proposição deste sistema ainda na década de $70^{61,63}$ e de atualização do mesmo até meados da década de $80^{102}$.

O seguinte fato talvez esclareça esta constatação: à crise de escassez de alimentos, no periodo 1972-74, seguiu-se uma crise de sobreoferta dos mesmos que, embora tenha tido efeitos fortemente desestabilizadores nos preços internacionais, secundarizou a discussão da SA, que, à época, se restringia à idéia de produção suficiente de gêneros ${ }^{179}$.

Esta discussão foi retomada na década de 80 , quando da ampliação da crise econômica internacional de caráter recessivo, que afetou profundamente a qualidade de vida principalmente das populações de baixa renda dos países não-desenvolvidos. Este periodo foi marcado, de maneira geral, pelo aumento do desemprego e da inflação, queda dos salários reais, diminuição dos gastos públicos em áreas ligadas à alimentação e nutrição e aumento (ou, pelo menos, desaceleração da queda) da mortalidade infantil e da desnutrição 40,60,179.

Reconheceu-se, nesta época, que a oferta suficiente de gêneros alimentícios não garantia o acesso universal aos alimentos básicos, sendo então revisitado e reformulado o conceito de $\mathrm{SA}^{48,157,179}$. Este, sistematizando o que é desejável de ser alcançado pelos paises em geral em termos de alimentação, passou a ter como objetivo final 
"(...) assegurar em todo momento e a toda população, a possibilidade material e econômica de obter os alimentos básicos de que necessita" (FAO, 1983 apud ORALC/FAO, sd, p. 1)*.

E, como objetivos especificos:

(...) assegurar a produção de alimentos em quantidades suficientes; conseguir a máxima estabilidade dos subsídios de tais alimentos e garantir a possibilidade de obtenção dos alimentos àqueles que necessitam" (FAO, 1983 apud ORALC/FAO, sd, p. 2).

$\mathrm{Na}$ operacionalização desta formulação, são comuns dois enfoques que se complementam. $O$ primeiro valoriza a capacidade de os paises que apresentam déficits alimentares satisfazerem minimamente as necessidades nutricionais dos individuos ou familias. $O$ segundo se refere ao grau de auto-suficiência no abastecimento de alimentos, de acordo com padrões pré-estabelecidos ${ }^{48,60}$.

Quatro problemas alimentares embasam a formulação de SA, quais sejam ${ }^{60,179}$ :

1. desequilibrios conjunturais de disponibilidade de alimentos, relacionados com lacunas cíclicas entre a produção e a demanda de alimentos;

2. desequilibrios estruturais de disponibilidade dos alimentos, ligados a lacunas persistentes entre produção e demanda;

3. desequilibrios cíclicos ou sazonais de acesso aos alimentos, devido à ocorrência de dificuldades ocasionais, que impedem determinadas familias de satisfazerem seus requerimentos nutricionais básicos, $\mathrm{e}$

4. restrições estruturais de acesso, que se referem a uma lacuna sistemática, em determinados setores sociais, entre as necessidades nutricionais e a renda disponivel para o consumo alimentar.

Embora estes problemas apresentem algum grau de interligação, são determinados por fatores diferentes. Portanto, são necessárias medidas de naturezas distintas para sua solução, buscando-se a obtenção de uma disponibilidade nacional de alimentos que reúna, simultaneamente, as seguintes caracteristicas: suficiência, estabilidade, autonomia, eqüidade e sustentabilidade, descritas a seguir ${ }^{48,60,69,181}$ :

1. Suficiência - diz respeito à capacidade de se gerar, através de produção interna e importaçōes, uma oferta adequada de alimentos que atenda à demanda efetiva existente $e$ às necessidades alimentares básicas das camadas de baixa renda (demanda potencial);

2. Estabilidade - refere-se à intensidade das flutuaçōes a que está submetida a disponibilidade de alimentos ao longo do tempo, expressando a capacidade de serem neutralizadas as inevitáveis flutuações ciclicas;

3. Autonomia - expressa o grau de vulnerabilidade ou dependência externa do sistema 
alimentar. Na perspectiva da SA, o objetivo seria lograr auto-suficiência nacional pelo menos na produção dos alimentos básicos;

4. Eqüidade - relaciona-se à universalidade do direito de acesso ao mínimo nutricional, do ponto de vista quantitativo e qualitativo. Embora haja consenso sobre o direito universal de acesso aos alimentos, as formas de sua materialização são as mais diversas, variando desde uma prática permeada pela concepção de que o funcionamento irrestrito do mercado irá determinar o quanto cabe a cada um, até uma que estabelece mecanismos para assegurar um acesso igualitário, o que, muitas vezes, supõe racionamento, e

5. Sustentabilidade - corresponde à capacidade de o sistema assegurar o alcance, a curto e longo prazos, da estabilidade, suficiência, autonomia e eqüidade distribuitiva, garantindo-se a preservação dos recursos naturais.

Atualmente, cada vez mais o alcance da SA tem se apresentado como um objetivo central da politica alimentar de diversos paises, alcançando-se um consenso que transcende a posição destes no mercado alimentar mundial e as características dos regimes políticos vigentes 42,48 .

Entende-se, portanto, que, mais do que o enfoque multisetorial da problemática nutricional e seu desdobramento através de politicas coerentes com ele, faz-se necessário o estabelecimento de relações entre os vários setores ${ }^{48}$. A partir desta concepção, vem-se incentivando a articulação entre os conceitos de SA e de SISVAN, resgatando-se o papel intersetorial deste último como um sistema de informaçōes que subsidiaria as políticas voltadas para o alcance da $\mathrm{SA}^{9,157,158}$.

\section{O SISVAN no Brasil}

Será enfocado, fundamentalmente, o desenrolar da proposta de sisvaN no âmbito do governo federal. Para maior aprofundamento desta discussão, será traçado um paralelo entre a história daquele sistema e a das políticas sociais de alimentação e nutrição desenvolvidas no Brasil a partir da década de 70 .

\section{Os anos 70 e 80}

Fruto da evolução das politicas sociais de alimentação e nutrição e das instituições responsáveis por sua execução, foi criado, em 1972, o Instituto Nacional de Alimentação e Nutrição (INAN), autarquia vinculada ao Ministério da Saúde, cujo papel era formular uma politica na área de alimentação e nutrição para o pais ${ }^{96,180,197}$. Como será visto a seguir, este órgão teve participação relevante tanto na proposição e execução de políticas nesta área como na tentativa de estruturação do SISVAN em nivel nacional.

A partir de 1974, concomitantemente, portanto, à proposição internacional do sISVAN, a politica social, antes presente de maneira tímida e desarticulada no discurso do Es- 
tado brasileiro, passou a ganhar maior visibilidade, sendo assumida como um dos eixos do mesmo. Além de receber maior alocação de recursos que no período anterior, passou a ter objetivos próprios, sendo marcada pela ênfase no seu papel redistributivo em relação à renda e preventivo em relação à saúde, dirigida à população com baixo poder aquisitivo e sendo viabilizada através de uma série de programas ${ }^{26,162}$.

$O$ primeiro modelo de uma politica social com dimensão nacional foi sistematizado, em 1976, no Programa Nacional de Alimentação e Nutrição (PRONAN II) - o PRONAN I não chegou a ser implementado. Englobava programas de suplementação alimentar, alimentação do trabalhador, amparo ao pequeno produtor rural, combate às carências específicas e apoio à realização de pesquisas e capacitação de recursos humanos ${ }^{180}$.

Como exemplos podem ser citados o Projeto de Abastecimento em Áreas de Baixa Renda, Racionalização da Produção de Alimentos Básicos e os Programas de Alimentação do Trabalhador, Nacional de Alimentação Escolar, de Comercialização e Abastecimento em Áreas Rurais, de Complementação Alimentar, Combate às Carências Nutricionais Especificas e de Nutrição em Saúde (PNS) ${ }^{97,139,162,180}$. Este último, por ser vinculado diretamente à rede de saúde, será brevemente comentado.

Iniciado em 1975 e melhor estruturado em 1976, o PNS tinha como objetivos: reduzir a prevalência de carências nutricionais, aumentar a resistência a diversos agravos, diminuindo a morbimortalidade e a pressão sobre os serviços de saúde e melhorar, indiretamente, a distribuição de renda ${ }^{97,139,162,180}$.

Seu eixo de ação foi a suplementação alimentar para gestantes, nutrizes e crianças de seis meses a sete anos (incompletos) de idade cuja familia apresentasse renda inferior a dois salários minimos. Sua operacionalização se deu através da distribuição de alimentos básicos in natura via secretarias estaduais de saúde, sob supervisão do INAN.

Este programa se propunha a incentivar a integração dos serviços públicos estaduais com o Ministério da Saúde, associando suas ações à prestação de ações básicas. Os beneficiários deveriam ser selecionados nas unidades de assistência à saúde, sendo priorizadas as gestantes que tivessem filhos desnutridos e condições biológicas tidas como de risco, além das crianças filhas destas gestantes. Embora mencionados, não foram normatizados critérios orgânicos para seleção dos beneficiários, sendo formalizados somente os de idade e faixa de renda.

Simultaneamente, ainda na década de 70, foram formuladas, por parte do INAN ou a seu pedido, propostas de viabilização do SISVAN bastante consistentes tecnicamente, tendo sido feitas, em 1976, as primeiras tentativas de implantação, que não sairam do papel ${ }^{195}$.

Em 1977, novos documentos foram escritos e outra vez não resultaram em desdobramentos concretos. Em 1981, a vigilância alimentar e nutricional, através de dispositivos legais, passou a compor as atribuições da Secretaria de Programas Especiais do INAN, sendo que as propostas então formuladas não conseguiram ultrapassar a fase piloto ${ }^{195}$.

As primeiras tentativas efetivas de implantação desta proposta ocorreram entre 1983 e 1984, em áreas dos estados da Paraiba e de Pernambuco, através de convênio firmado entre o INAN, a Fundação Instituto de Planejamento (PB) e a Fundação Joaquim Nabuco (PE), separadamente. Os projetos não sobreviveram à fase experimental, sucumbindo no ano seguinte, quando o INAN suspendeu o financiamento ${ }^{12,17,195}$. 
Paralelamente, entre 1980 e 1984, os programas de alimentação descritos anteriormente tiveram continuidade, inclusive com aumento dos recursos neles alocados, não conseguindo, entretanto, nem de longe, acompanhar as perdas salariais ocorridas no periodo 162 .

Em 1985, na passagem do regime militar para o civil, com o advento da Nova República, houve maior alocação de recursos na área de politicas sociais, entre elas as de alimentação e nutrição. Ocorreram, também, algumas modificações no discurso sobre as politicas sociais e na orientação dos programas já existentes, sendo também criados outros novos $162,180,197$.

Em relação ao discurso governamental, o eixo passou da "proteção aos grupos sociais e biologicamente vulneráveis à desnutrição" para a "política de combate à fome e ao desemprego". Retoma-se, portanto, aqui, em lugar da desnutrição, o uso da palavra fome, cuja menção nos documentos oficiais havia sido proibida durante o regime militar ${ }^{76}$. Este eixo, no entanto, foi, aos poucos, sendo relativizado nos documentos oficiais, prevalecendo a idéia de que a "(..) essência da gênese e reprodução da miséria social e da fome/desnutrição (...) é inatingivel" (Vasconcelos, 1988, p. 44).

Quanto à reorientação dos programas já existentes, destacaram-se as tentativas de descentralização das atividades e de racionalização dos gastos públicos, buscando garantir maior efetividade. Além da continuação destes, foram criados o Programa de Abastecimento Popular e o Programa Nacional do Leite para Crianças Carentes 12,162,180,197.

Nas análises realizadas por inúmeros autores sobre estes programas desenvolvidos

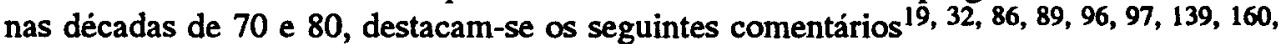
$162,163,165,169,180,181,197$.

1. funcionaram de forma paralela, não se associando de maneira sistemática à saúde e à educação, havendo, muitas vezes, superposição de beneficiários;

2. sua cobertura real foi muito menor do que a anunciada oficialmente, sendo deficiente em áreas e grupos mais vulneráveis;

3. tiveram atuação irregular, no sentido de haver interrupções no fornecimento de alimentos ou no subsídio ao pequeno produtor;

4. muitos deles veicularam alimentos industrializados, beneficiando grandes indústrias, afastando-se da idéia inicial de serem privilegiados os produtos in natura e os pequenos produtores;

5. foram criticados, muitas vezes, pela má qualidade dos alimentos fornecidos;

6. mais que a função de garantir boa alimentação e melhoria da situação nutricional da população, foram pensados com o intuito de servir como um estímulo à ida aos serviços de saúde ou à diminuição do absenteísmo nas escolas ou locais de trabalho;

7. por motivos de alocação de recursos e operacionais, os estratos de maior renda e regiōes mais desenvolvidas do pais apresentaram melhor evolução dos indicadores antropométricos, indicando que se mantiveram as diferenças regionais existentes; 
8. serviram como instrumentp de manipulação política, particularmente em períodos eleitorais, e de reforço à dependência do clientelismo estatal;

9. tiveram sua operacionalização extremamente centralizada no nivel federal, dependente de uma série de instituições emaranhadas numa complexa teia burocrática, dando margem para irregularidades administrativas, desvios e corrupções nos mais diversos niveis de atuação, como, por exemplo, concorrências ilícitas de empresas fornecedoras de alimentos;

10. até a realização da Pesquisa Nacional de Alimentação e Nutrição - PNSN, em 1989, não havia ocorrido, em nivel nacional, uma avaliação da implementação destes programas;

11. em térmos globais, não foram suficientes para alterar o quadro alimentar e nutricional do pais.

Paralelamente à execução destes programas, foram iniciadas, entre 1987 e 1989, experiências de implantação do SISVAN em diferentes estados (e.g. Pernambuco, São Paulo e Ceará) e municípios (e.g. Rio de Janeiro) que, embora tenham tido papel fundamental na experimentação da proposta e no amadurecimento de sua operacionalização ${ }^{17}$, não tinham a possibilidade de deslanchá-la e articulá-la em nivel nacional.

\section{Os anos 90}

A dimensão nacional do SISVAN só começou a se viabilizar no início dos anos 90 , quando foi instituído legalmente pelo Ministério da Saúde ${ }^{10,12,31}$ e o INAN, como instância governamental federal, assumiu o papel articulador das experiências existentes e normatizador de um sistema minimamente padronizado, que permitisse a comparação de dados produzidos em diferentes realidades 60 .

Ainda em 1990 e durante parte de 1991, o INAN investiu na articulação entre as experiências de SISVAN nos diversos estados e municipios. Definiu, para tal, duas diretrizes: apoio à operacionalização deste sistema, através de convênios com instâncias interessadas, e padronização dos indicadores de estado nutricional e pontos de corte para fins de Vigilância Nutricional (VN) ${ }^{84}$. Para a viabilização destas diretrizes, foi constituído o Grupo Técnico de Coordenação Executiva - GT-SISVAN, tendo como atribuição a promoção de ações necessárias para a implantação do $\operatorname{SISVAN}^{30}$.

No entanto, neste mesmo periodo, o INAN sofreu progressivo enfraquecimento político, passando, durante vários meses, por indefinição dos quadros dirigentes e do seu papel institucional ${ }^{164}$, o que limitou seus investimentos nesta área.

Ainda no inicio dos anos 90 , outro fato no campo legislativo merece destaque: na Lei Orgânica do Sistema Único de Saúde, a inclusão da VN e da orientação alimentar como responsabilidade deste ${ }^{29}$. Como desdobramento desta, nas discussões sobre a reforma administrativa do Ministério da Saúde, vem sendo proposto um departamento de Vigilância Nutricional, que, junto com os departamentos de Vigilância de Agravos à Saúde, 
Vigilância de Produtos, Processos e Serviços, de Saneamento e Meio Ambiente e de Operações, comporia a subsecretaria de Vigilância da Secretaria de Atenção à Saúde ${ }^{129}$.

No campo das políticas sociais de alimentação e nutrição, no periodo entre 1990 e início de 1993, o discurso oficial do Poder Executivo foi o do atendimento integral à criança como prioridade social, explicitado em planos e projetos bastante indefinidos em termos de estratégia de operacionalização ${ }^{164}$. Concretamente, o que se observou foi

"(...) uma redução significativa dos programas nacionais de alimentação e nutrição, tanto nas suas metas de atendimento quanto nos volumes de recursos dispendidos" (Peliano \& Beghin, 1992, p. 1),

resultando na

"(...) eliminação, após 1991, de todos os programas voltados para o grupo materno-infantil (...) e a redução no periodo de atendimento da merenda escolar para apenas 32 dias letivos" (Peliano \& Beghin, 1992, p. 1).

O enxugamento dos recursos era, a princípio, recomendável, visto a grande superposição apresentada pelos programas em termos de população alvo e atividades desenvolvidas. No entanto, a ele não se seguiu uma redefinição das políticas de alimentação e nutrição. Na verdade, o que se observou, apesar do discurso oficial citado anteriormente, foi a falta de prioridade politica para esta área ${ }^{163,164}$.

As poucas iniciativas que se mantiveram foram aquelas voltadas

"(...) à garantia de mercado às indústrias modernas de alimentos (via Programa de Suplementação Alimentar, mẹrenda escolar etc.) e ao subsidio direto ao capital por intermédio do Programa de Alimentação do Trabalhador. Em paralelo, continuam a ser montados programas de distribuição de cestas de alimentos (industrializados), em bases clijentelistas que vêm gerando episódios de escândalo e corrup̧ão (...)" (Silva \& Silva, 1991).

No âmbito do Poder Legislativo, entre maio de 1991 e maio de 1992, foi realizada a Comissão Parlamentar de Inquérito (CPI) da Fome, "destinada a examinar as causas da fome e a iminente ameaça à segurança alimentar" (Brasil, 1992, p. 1).

Fizeram parte do relatório final desta CPI, entre outras, as seguintes conclusões e recomendações $^{32}$ :

1. o Brasil possuiria condições naturais e humanas para produzir alimentos suficientes para toda a população, mas mais de 70 milhões de brasileiros não tinham acesso a uma alimentação minimamente suficiente para suprir suas necessidades nutricionais;

2. a fome seria uma das manifestações sociais da miséria, e a desnutrição, a manifestação da fome no individuo, sendo o estado nutricional de uma determinada população um claro indicador de seu estágio de desenvolvimento econômico e social; 
3. nos programas assistenciais de distribuição de alimentos, entre outras críticas e constatações, foram evidenciados "veementes indícios da existência de cartelização no mercado de alimentos formulados" (p. 7), sendo indicada a apuração das irregularidades licitatórias e a unificação dos programas alimentares, com utilização de produtos básicos, com progressiva desativação;

4. a primeira causa determinante da fome no Brasil seria a má distribuição de renda, uma das piores do mundo, acentuada ao longo de sucessivas políticas recessivas. Portanto, a solução definitiva para a fome passaria necessariamente pela mudança do modelo econômico vigente, devendo ser assumido como prioridade o atendimento às necessidades básicas da população e

5. seria imprescindivel uma política de apoio aos pequenos e médios produtores rurais, redefinição da política de abastecimento e reforma tributária para os produtos básicos, entendendo-se o barateamento alimentar como estratégico para a retomada do crescimento econômico.

Chamou atenção, nesta iniciativa do Legislativo, a ausência de comentários, neste documento, sobre as irregularidades existentes na área de politicas de irrigação no Nordeste - a "indústria da seca". Por outro lado, foi explicitada a preocupação com o alcance da Segurança Alimentar,

"(...) entendida como coordenação e integração de mecanismos governamentais para garantir o consumo diário de alimentos em quantidade e qualidade, a fim de suprir as necessidades nutricionais de cada individuo" (Brasil, 1992, p. 2).

Além da CPI da Fome, ocorreram, no início da década, outros fatos de interesse para esta análise, como, por exemplo, os decorrentes do processo de impeachment do presidente da República, em 1992, experiência internacional inédita.

$O$ desdobramento deste, em termos da abordagem da questão alimentar e nutricional, foi marcado por acontecimentos também inéditos: a fome, a desnutrição e a falta de acesso aos alimentos para uma grande parte da população passaram a ter prioridade dentro de vários movimentos e instituições da sociedade civil, bem como na agenda dos organismos governamentais ${ }^{46,81,91,92}$.

Esta mobilização nacional teve como marco a estruturação do Movimento de Combate à Fome, à Miséria e Pela Vida, originado da ampliação do Movimento pela Ética na Política, criado em 1992 por diversos órgãos e entidades da sociedade civil, quando do processo de impeachment. Após a conquista de seus objetivos iniciais, ganhou nova dimensão, originando o "Movimento da Fome", como é amplamente chamado, sob a coordenação nacional do sociólogo Herbert de Souza ${ }^{46,81}$.

Desde então, uma série de iniciativas foram viabilizadas. No campo da ação governamental federal, merecem destaque quatro iniciativas.

A primeira, que desencadeou as demais, foi a incorporação, pelo governo de então, do documento "Política Nacional de Segurança Alimentar" (PNSA), formulado pelo Go- 
verno Paralelo. Este foi fundado em 1990, pelo Partido dos Trabalhadores, com o intuito de fiscalizar o governo eleito diretamente em 1989 e propor politicas alternativas para o pais $^{91,181}$.

Neste documento, em consonância com o que preconiza a FAO (1988), como já abordado anteriormente, afirmou-se que o papel da PNSA seria assegurar a todos os brasileiros, em todo momento, o acesso aos alimentos básicos que necessitassem, assumindose o pressuposto de que as chamadas "leis do mercado" não seriam capazes de solucionar os problemas centrais do subdesenvolvimento (fome, desequilibrios sociais e regionais, entre outros) e garantindo-se uma abordagem estratégica,

"(...) oposta ao enfoque restritivo que transforma a fome e a desnutrição num problema, a ser enfrentado por programas sociais compensatórios da pobreza" (Silva \& Silva, 1991, p. 7).

Entre as medidas apontadas como condicionantes do alcance da Segurança Alimentar figuraram: crescimento do emprego e a recuperação dos salários, com crescimento sustentado das atividades econômicas; politica de expansão da produção agroalimentar, investindo-se na busca de auto-suficiência na produção dos gêneros básicos e reforma agrária e barateamento relativo dos alimentos básicos, com controle de preços e margens de lucro daqueles incluídos na cesta básica ${ }^{76,181}$.

A segunda iniciativa, que concretizou a parceria entre governo e sociedade civil, foi a criação do Conselho Nacional de Segurança Alimentar (Consea), presidido pelo próprio presidente da República e composto por 8 ministros e 21 membros notáveis da sociedade civil, escolhidos e demissiveis por iniciativa presidencial. A esta nova instância foram atribuidas as funções de consulta, assessoria $e$ indicação de prioridades em relação às medidas de combate à fome e às políticas que buscassem alcançar a Segurança Alimen$\operatorname{tar}^{28,51}$.

A terceira foi a elaboração do Mapa da Fome pelo Instituto de Pesquisa Econômica Aplicada (IPEA), órgão ligado ao Ministério de Planejamento, que teve o papel de dimensionar a população que apresentava condições mais graves de insuficiência alimentar, através de indicadores de indigência $e$ fome, $e$ de tecer considerações sobre prioridades de intervenção para o enfrentamento do problema alimentar no pais ${ }^{161}$.

A outra iniciativa importante foi a formulação do "Plano de Combate à Fome e à Miséria - Principios, Prioridades e Mapa das Ações de Governo", que sistematizou as principais ações a cargo do governo, os princípios que as nortevam e as ações específicas de cada ministério ${ }^{45}$.

Como medida emergencial de combate à fome, na área de politicas sociais de alimentação e nutrição, foi implemementado o "Programa de Atendimento a Crianças Desnutridas e Gestantes de Risco Nutricional - Leite é Saúde", direcionado para crianças desnutridas entre seis meses e dois anos de idade, seus contatos familiares e gestantes sob risco nutricional.

Embora tenha surgido como resposta ao movimento de combate à fome e à miséria, este programa foi estruturado com o objetivo de reduzir a desnutrição. Não há dúvida 
que, em várias realidades, a redução da pobreza, do "gap" alimentar e da desnutrição são objetivos que podem apresentar interfaces. No entanto, a tradução destes na estrutura de programas de suplementação alimentar guarda especificidades, por exemplo, nos critérios de escolha de beneficiários, nos alimentos a serem distribuídos, na forma de distribuição destes alimentos, entre outros ${ }^{71}$. Portanto, esta dubiedade entre o objetivo primeiramente anunciado (redução da miséria e da fome) e o de fato estruturado (redução da desnutrição) deve ser afastada, de forma a evitar expectativas inatingiveis e frustrações posteriores entre os que elaboram e executam o programa.

Afora o aspecto abordado acima, o desenho do programa em questão explicita a tentativa de superação de alguns dos pontos negativos ocorridos em experiências nacionais e internacionais anteriores ${ }^{71,72}$ : (a) aquisição dos alimentos descentralizada, feita pelos próprios municípios, com verba repassada pelo Ministério da Saúde; (b) distribuição de alimentos (leite integral - em pó ou fluido - e óleo de soja) através da rede de saúde, explicitamente articulada às ações básicas; (c) concentração das ações, no caso das crianças, na faixa etária que apresenta maior chance de resposta a programas com este perfil e (d) seleção dos beneficiários nos próprios serviços, segundo critérios antropométricos, rotinizados pelo sisvaN. Para que este programa se viabilizasse, portanto, um dos pré-requisitos seria a implantação do sisvaN na rede de saúde ${ }^{45,125}$.

Observe-se, portanto, que a história do sisvaN no Brasil teve uma trajetória própria, já sendo realidade em vários municípios e estados quando, em 1993, com o deslanchar do Movimento de Combate à Fome, o governo federal incorporou, pela primeira vez, a SA como pano de fundo para a formulação de suas politicas e o SISVAN como um dos instrumentos para sua viabilização.

Até então, não tinha havido, em termos de normatização governamental, a mencionada articulação entre as políticas viabilizadas, a SA e o SISVAN. Isto a despeito de terem sido mencionadas, na formulação de inúmeros programas, a necessidade de se garantir alimentação às populações mais pobres e a prioridade de cuidados aos grupos biologicamente vulneráveis, em particular os desnutridos ${ }^{96,97,162,197}$; argumentações semelhantes às apresentadas internacionalmente para a proposição do SISVAN.

Vale ressaltar que, no ano de 1992, tanto o SISVAN como a Segurança Alimentar foram mencionados em dois documentos de instâncias ligadas ao governo federal: a SA, na CPI da Fome, e a Vigilância Nutricional, citada como vigilância alimentar, mas operacionalizada dentro do Sistema Único de Saúde, em relatório do IPEA, a partir de análise sobre a situação das politicas de alimentação e nutrição ${ }^{163}$.

É fato que, neste momento de ampla discussão sobre as participações do governo, da sociedade civil e da midia frente à questão da fome e da miséria, o sISVAN ganhou maior respaldo político junto aos organismos governamentais. No entanto, o papel a ele atribuído restringiu-se às políticas sociais e ao Ministério da Saúde, sendo caracterizado, fundamentalmente, como instrumento de triagem de beneficiários de programas de suplementação alimentar ${ }^{71}$. Não lhe foi conferida, portanto, a dimensão intersetorial preconizada pelos organismos internacionais que of formularam ${ }^{63,102,154}$.

Observe-se, portanto, que, no Brasil, o SISvAN caminhou, durante muitos anos, paralelo às políticas e programas federais, inclusive de alimentação e nutrição. Ademais, 
quando o debate político deu elementos para que tomasse dimensões intersetoriais, foi vinculado exclusivamente ao setor saúde, com o papel de racionalizar ações de suplementação alimentar.

Além destas caracteristicas, outras, semelhantes às dos paises não-desenvolvidos, compõem a situação atual do SISVAN no Brasil ${ }^{17}$ :

1. tem se resumido, praticamente, a variáveis antropométricas, principalmente de crianças menores de cinco anos, sendo, portanto, um instrumento limitado até mesmo para o setor saúde;

2. tem coberturas geográfica e populacional restritas, exceto em alguns projetos localizados;

3. o trabalho de geração e consolidação dos dados tem ocupado a maior parte do tempo dedicado pelos técnicos ao SISVAN, ficando sua interpretação e aplicação secundarizadas;

4. tem tido, em consequiência, pouca utilidade. 


\section{Saúde e nutrição da população brasileira}

Neste capítulo serão comentados os perfis demográfico, de morbimortalidade e de nutrição da população brasileira nas últimas duas décadas. Quando for relevante para a discussão, estas informações se estenderão à década de 30 .

A discussão sobre perfil de nutrição poderia vir inserida na de morbimortalidade, uma vez que, em uma das premissas desta dissertação, assume-se o perfil nutricional como componente do processo saúde-doença da população. No entanto, pelo fato de o sisVAN, historicamente na área da saúde, ter sido direcionado aos agravos nutricionais exclusivamente, faz-se necessária uma revisão mais aprofundada desta dimensão, com vistas a melhor subsidiar a reflexão realizada no capitulo 4.

Mesmo sendo de amplo conhecimento, não se pode deixar de registrar que, embora se deseje discutir o perfil de saúde da população, só estão disponiveis, e ainda assim com restrições quantitativas e qualitativas, dados de sua ausência: mortes e agravos em geral: doenças infecciosas ou não, acidentes de trânsito, de trabalho, incapacidade temporária ou permanente, entre outros.

\section{A transição epidemiológica}

Uma forma bastante corrente de se analisar a evolução do perfil de saúde de uma população é a comparação de situações de mortalidade em diferentes momentos. Vários fatores podem ser os responsáveis por uma alteração nem sempre real deste perfil, principalmente quando os momentos comparados situam-se distantes no tempo. Entre os que podem levar a mudanças reais figuram ${ }^{100}$ :

1. alteração na duração da doença (sobrevivência) devido ao diagnóstico precoce e melhoria nas técnicas de tratamento (diminuição da letalidade) e

2. mudança na incidência do agravo como resultado de, por exemplo, fatores comportamentais ou ambientais.

Entre os fatores que podem levar a mudanças artificiais figuram ${ }^{79,100}$ :

1. alterações nas técnicas de diagnóstico: técnicas mais apuradas (a) diagnosticando ca- 
sos que antes não seriam incluidos como sendo da doença em questão e/ou (b) deixando de diagnosticar como casos os conjuntos de sinais e sintomas antes interpretados como sendo da doença em questão;

2. alteração não exatamente da técnica de diagnóstico, mas da classificação do agravo em determinada codificação, como o Código Internacional de Doenças ou similares;

3. alterações na capacidade de delimitar a população sob risco (alterando o denominador da taxa) e

4. modificação na estrutura etária da população com manutenção das taxas de mortalidade em cada faixa etária.

Estes últimos fatores, no entanto, não serão valorizados, uma vez que serão enfatizadas as tendências gerais da evolução do perfil de mortalidade da população brasileira, mais que os valores numéricos das taxas propriamente ditos. Estes, quando mencionados, o serão em caráter ilustrativo.

O conceito que parece melhor sistematizar estas tendências gerais de evolução é o de transição epidemiológica, por conferir-lhes uma abordagem mais dinâmica - analisando-as sob uma perspectiva processual - e global - articulando-as com as mudanças no perfil demográfico e socioeconômico da população $6,98,146,167,168$.

Antes de uma análise da situação brasileira sob a ótica desta proposta, porém, fazse necessário resgatar não só seu conteúdo inicial mas também as revisões que este vem sofrendo atualmente.

O conceito de transição epidemiológica refere-se às complexas mudanças nos padrões de saúde e doença, predominantemente mortalidade e morbidade, que ocorrem em populações especificas, através do tempo. Refere-se, também, às interações destes padrões e seus determinantes e conseqüências demográficas, econômicas e sociais. Nesta transição, as doenças infecciosas associadas com carências primárias (condiçōes de moradia, nutrição, formecimento de água) são substituídas por doenças crônico-degenerativas e causadas pelo homem (lesões, padecimentos mentais), como principais causas de morte ${ }^{67,68,146,167,168}$. Em linhas gerais, hả declínio da mortalidade e aumento da morbidade, uma vez que mudam não só os tipos de doenças, mas também suas caracteristicas de duração: antes, predominantemente agudas e de letalidade alta, passam a ser de longa duração, acarretando um acúmulo de doentes, particularmente nas faixas etárias mais avançadas ${ }^{98}$.

Segundo Omran (1971), primeiro autor a sistematizar este conceito, cinco proposições básicas o compõem, quais sejam:

1. a mortalidade é um fator fundamental na dinâmica populacional;

2. durante a transição, ocorre uma mudança de longa duração nos padrões de mortalidade e doença, na qual as doenças infecciosas são gradualmente substituidas por doenças degenerativas e causadas pelo homem como a forma principal de morbidade e primeira causa de morte; 
3. durante a transição, as mudanças mais profundas nos padrões de saúde e doença ocorrem entre crianças (principalmente) e mulheres jovens;

4. as mudanças nos padrões de saúde e doença que caracterizam a transição estão estreitamente associadas às transições demográfica e socioeconômica que caracterizam a modemização;

5. as variações peculiares no padrão, velocidade (ritmo), determinantes e conseqüuências da mudança populacional diferenciam três modelos básicos de transição epidemiológica:

5.1. clássico ou ocidental: descreve quedas graduais e progressivas da mortalidade e da fecundidade, acompanhando o processo de modernização das sociedades européias ocidentais. Os fatores socioeconômicos foram os principais determinantes desta transição, sendo ampliados por medidas de saúde pública no século XX;

5.2. acelerado: descreve uma transição semelhante à anterior, só que ocorrida posteriormente e num periodo de tempo relativamente curto. Tem como exemplo o Japão;

5.3. contemporâneo ou tardio: descreve uma transição relativamente recente e a ser completada na maioria dos países não-desenvolvidos. É marcado por queda substancial da mortalidade a partir da II Guerra Mundial e manutenção de alta fertilidade, tendo as medidas de saúde pública um papel decisivo nesta transição.

Ainda segundo este autor, independentemente do modelo seguido, três estágios sucessivos principais compõem a transição epidemiológica: o primeiro, a "Era da Pestilência e da Fome", com altas taxas de mortalidade e baixa expectativa de vida. O segundo, a "Era do Declinio das Pandemias", com queda gradativa da mortalidade, aumento da expectativa de vida e grande crescimento populacional. $O$ terceiro, a "Era das Doenças Degenerativas e Causadas pelo Homem", quando a mörtalidade continua a declinar e até alcança estabilidade em niveis relativamente baixos, a expectativa de vida aumenta e a fertilidade passa a ser o principal fator no crescimento da população.

Todos os paises, portanto, passariam pelos mesmos estágios de transição, cada um destes caracterizado por um padrão dominante de morbimortalidade, estando as diferenças entre os diversos modelos, fundamentalmente, no momento do seu início e no ritmo de cada estágio.

Algumas formulações, apresentadas por outros autores nesta mesma época (início da década de 70) ou mais recentemente, utilizam conceitos semelhantes à proposição de Omran $^{68}$. Complementando o modelo deste autor, Olshansky e Ault (1986) sugerem um quarto estágio de transição epidemiológica: a "Era do Retardamento das Doenças Degenerativas", na qual há queda da mortalidade nas idades mais avançadas por retardamento das mortes por doenças crônicas, ficando a expectativa de vida acima de 80 anos.

Atualmente, vem sendo revista a pertinência destes conceitos, destacando-se os questionamentos apresentados a seguir.

A experiência de uma série de países de Terceiro Mundo indica não só que as etapas da transição podem se superpor, como também as mudanças nos padrões de morbi- 
mortalidade podem ser reversíveis. Portanto, não parece se aplicar a postulação de que a transição epidemiológica aconteceria de forma linear e seqüencial ${ }^{6,67,68,167}$.

Um segundo aspecto que vem sendo levantado atualmente é a crítica ao juizo de valor, implicito nas proposições clássicas, de que a substituição das doenças infecciosas por crônicas não-transmissiveis e acidentes ("doenças da civilização") seria um sinal de progresso. Estas últimas, portanto, não só seriam socialmente mais aceitáveis que as primeiras como também poderiam ser entendidas como conseqüência inevitável do processo de envelhecimento da população e, portanto, não passiveis de modificação ${ }^{67,68}$.

Contrapondo esta afirmação, autores afirmam que os agravos emergentes na transif̧ão seriam, na verdade, expressão de processos de industrialização, urbanização e consumo massivo que priorizaram o crescimento econômico em detrimento do bem-estar humano. Estes processos se traduziriam, entre outros, em problemas de poluição atmosférica (esta convivendo com a perene contaminação biológica), acidentes de trabalho e de trânsito, transtornos mentais, consumo de tabaco, álcool e drogas e hábitos alimentares pouco saudáveis.

Ademais, o declínio da prevalência das doenças cardiovasculares em paises do Primeiro Mundo sugere a possibilidade de uma nova transição nos mesmos ${ }^{98,168}$. Isto não só reforça a afirmação de que os agravos mais prevalentes depois da transição epidemiológica não são irredutiveis como, também, coloca para os paises não-desenvolvidos o desafio de superarem os agravos infecciosos e a desnutrição sem repetirem os padrões de morbidade dos paises desenvolvidos ${ }^{68}$.

Um terceiro questionamento à proposição clássica de transição epidemiológica diz respeito à idéia implícita de que as tendências na mortalidade têm correspondência na incidência das doenças, particularmente as transmissiveis. Embora possa ser real nos países desenvolvidos, nos outros esta assertiva não obrigatoriamente se confirma ${ }^{67,167,168}$.

Como mencionado anteriormente, naqueles paises, os principais fatores determinantes da queda da mortalidade por doenças transmissiveis foram de natureza socioeconômica, enquanto, nestes, estiveram mais relacionados a intervenções na área de saúde pública, as quais tiveram mais impacto nas taxas de mortalidade do que nas de incidência. Podem ser citadas, como exemplo, as técnicas de reidratação oral e de tratamento de infeç̧ões respiratórias ${ }^{67}$. Os agravos que tiveram suas incidência e mortalidade diminuídas com a implementação e ampliação do programa de imunização estão sempre sujeitos a recrudescimento, caso este programa, por alguma razão, diminua sua cobertura.

Complementando-se as ponderações levantadas anteriormente, frente à complexidade das experiências de transição epidemiológica vivenciadas nos paises da América Latina, a proposta de três modelos (clássico, acelerado e tardio) torna-se imprecisa, não conseguindo diferenciar paises com características bastante distintas.

Segundo Frenk et al. (1991), as diferentes experiências latino-americanas podem ser reunidas, de acordo com suas caracteristicas, em três grupos. $O$ primeiro abarca países como Cuba, Costa Rica e Chile, que estariam em uma etapa avançada da transição, seguindo uma modalidade semelhante à dos países desenvolvidos (modelo tardio). $O$ segundo reúne paises como Haiti, Bolívia e Peru, que estariam em uma etapa inicial de transição, com altos indices de mortalidade infantil e morbidade marcada por infeç̧ões e des- 
nutrição. O terceiro grupo é representado por países como o México, que estariam vivenciando uma nova experiência de transição, definida como sendo um modelo diverso, caracterizado como "modelo polarizado prolongado". Suas caracteristicas podem ser assim resumidas:

1. superposição de etapas, com proporções semelhantes de mortes por diarréias, doenças do aparelho respiratório, doenças cardiovasculares e causas externas;

2. contratransição, com recrudescimento de enfermidades transmissiveis, estas apresentando menor letalidade;

3. transição prolongada, com estancamento em uma situação de morbimortalidade mista. Embora os países desenvolvidos tenham convivido com a superposição de etapas e coexistência de tipos de morbidade, o que marca este modelo é o caráter prolongado desta situação;

4. polarização epidemiológica, caracterizada por diferenças qualitativas no perfil de morbimortalidade de diferentes regiōes geográficas e grupos sociais.

Cabe aqui uma ressalva sobre a proposição de 'transição prolongada'. Embora os autores critiquem a presença, na proposição clássica, da idéia subliminar de que a transição epidemiológica seria linear e seqüencial, parece ainda permanecer, nesta última proposição, a perspectiva de que todo pais chegará - mesmo que não de forma linear - a um padrão previsível de mortalidade tido como pós-transição. $O$ que o caracterizaria seria a "demora" na conclusão da transição e o "estancamento" em uma situação mista.

\section{Perfil de morbimortalidade}

A proposição que mais se aproxima da experiência do Brasil em termos de mudança do seu perfil de morbimortalidade é o modelo polarizado prolongado. Sua transição epidemiológica vem sendo marcada pela coexistência de distintos padrões de mortalidade, com aumento crescente do peso das doenças cardiovasculares, neoplasias e causas externas no seu perfil de mortalidade, ao lado de taxas ainda relevantes de mortes por doenças infecciosas. Somam-se a este perfil as altas prevalências de endemias como a doença de Chagas, esquistossomose, malária, além do recrudescimento da hanseniase e do dengue, reintrodução do cólera e aumento da incidência de AIDS6,98,167.

A polarização se expressa, de um lado, nas regiōes Norte e Nordeste, no meio rural e periferias urbanas (recorte geográfico) ou na população de baixa renda (recorte socioeconômico), pela predominância de morte por doenças infecciosas e causas mal definidas, evidenciando uma situação de carência de condições mínimas de vida, falta de assistência médica e má qualidade dos registros de óbito, classicamente comum aos paises subdesenvolvidos. De outro, nas regiōes Sul e Sudeste, em áreas mais centrais (recorte geográfico) ou na população de melhor renda (recorte socioeconômico), pela predominância de agravos crônicos e causas externas, evidenciando uma situação classicamente comum aos países desenvolvidos ${ }^{6,167}$. 
A seguir, serão apresentados dados que ilustram, sucintamente, os processos de transição demográfica e epidemiológica brasileiros.

No periodo de 1930 a 1970, registrou-se relevante queda da mortalidade geral e relativa estabilidade nos niveis de fecundidade, com aceleração do crescimento demográfico e manutenção da distribuição etária da população brasileira. A partir dos anos 70 , ocorreu uma rápida queda da fecundidade, desacelerando-se o ritmo de crescimento populacional, alterando-se a configuração da estrutura etária da população. Simultaneamente, elevaram-se a esperança de vida ao nascer $e o$ índice de envelhecimento - proporção de indivíduos com 65 anos e mais para cada cem indivíduos com quinze anos e menos $89,153,167$.

Estas mudanças, no entanto, não ocorreram de forma homogênea nem nos diversos setores socioeconômicos nem nas regiões do país. Dois exemplos desta segunda dimensão podem ser observados nos comportamentos da esperança de vida ao nascer e da fecundidade nas últimas décadas. Embora todas as regiōes geográficas apresentem tendências semelhantes de aumento, para o primeiro indicador, e de queda, para o segundo, há um claro gradiente entre elas, caracterizando a heterogeneidade referida acima (Figuras 5 e 6).

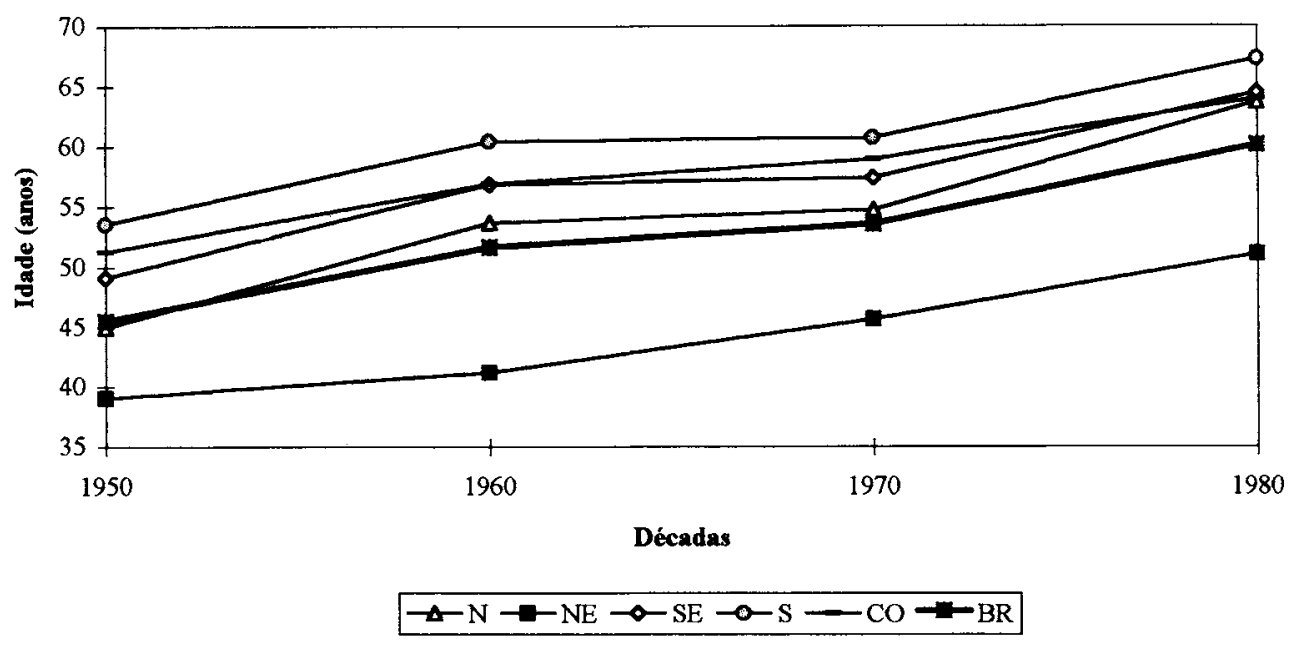

Figura 5 - Esperança de vida ao nascer por regiāo geográfica, Brasil, 1950 - 1980.

Desenhada a partir de dados obtidos em Possas (1989).

Acompanhando estas modificações, além da diminuição da mortalidade geral, houve importantes transformações no perfil de mortalidade da população brasileira ${ }^{6,168}$ : enquanto em 1930 as doenças infecciosas foram responsáveis por $46 \%$ e as do aparelho circulatório por $12 \%$ dos óbitos ocorridos, em 1985 representaram 7 e $33 \%$, respectivamente (Figura 7). Esta mudança de perfil também se deu de forma heterogênea nas diversas regiões geográficas. 


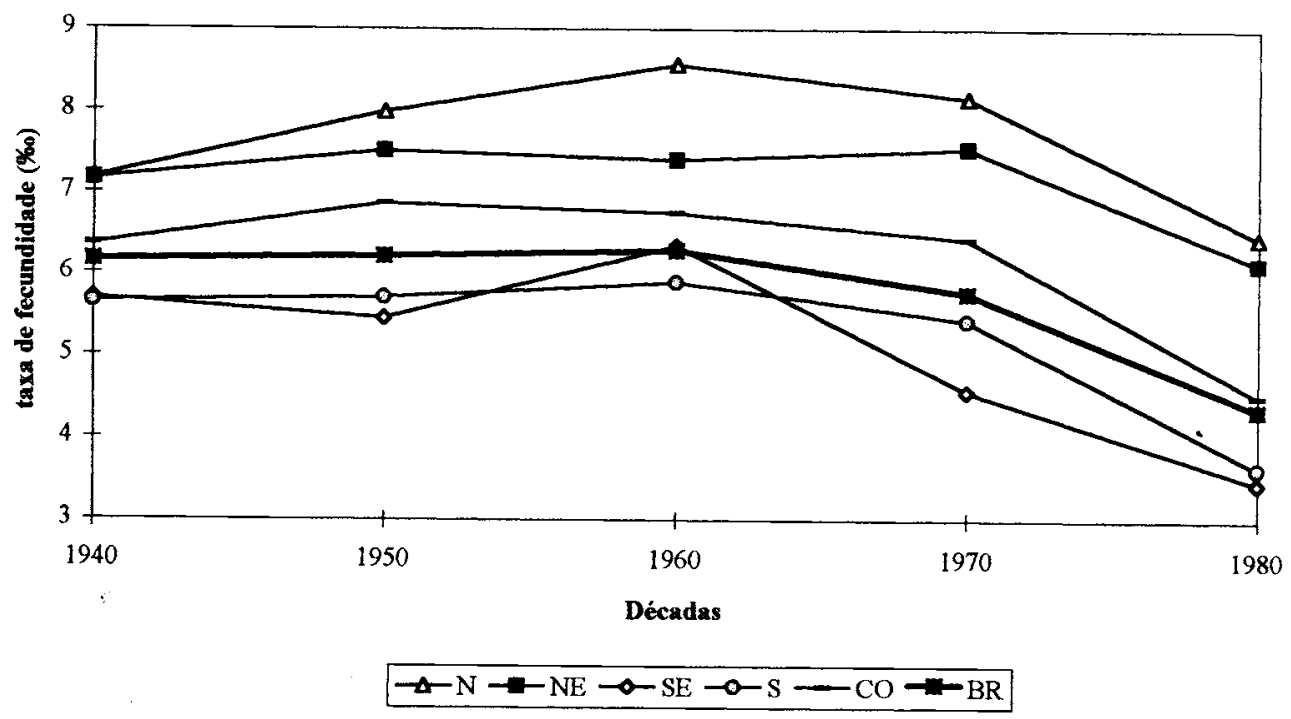

Figura 6 - Taxa de fecundidade total por região geográfica, Brasil, $1940-1980$. Desenhada a partir de dados obtidos em Possas (1989).

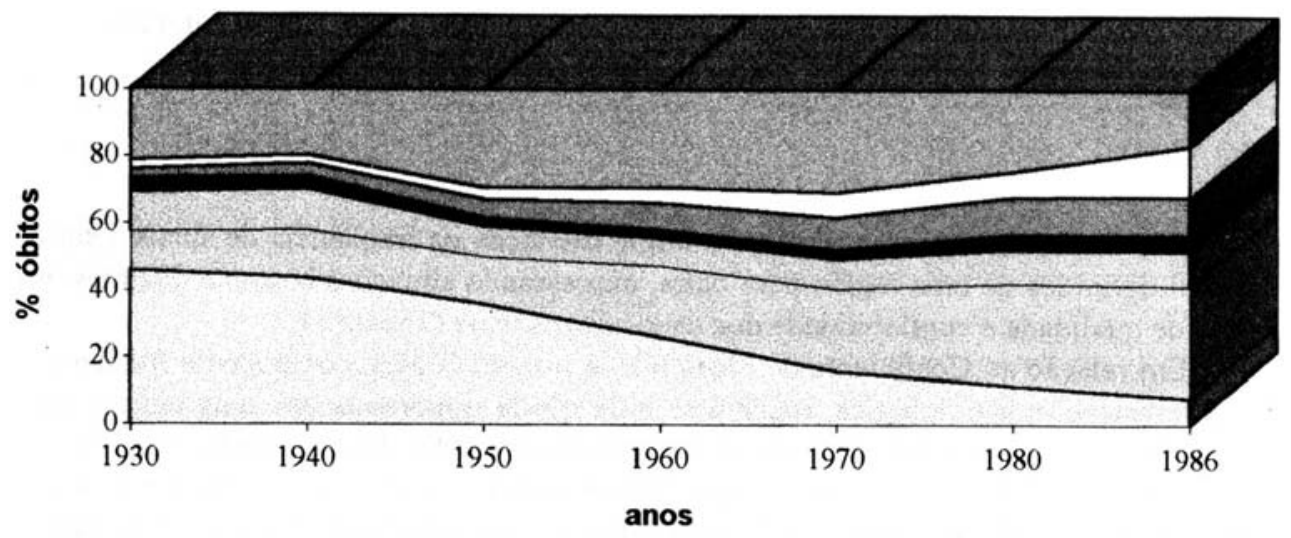

\begin{tabular}{lll}
\hline Doenças Infecto-parasitárias & $\square$ Aparelho Circulatório & $\square$ Aparelho Respiratório \\
Aparelho Digestivo & a Neoplasias & $\square$ Externas \\
a Outras & &
\end{tabular}

Figura 7 - Distribuição de mortes por grupos de causa, Brasil/capitais, 1930 - 1986.

Desenhada a partir de dados obtidos em Araújo (1992). 
Atualmente, as seis principais causas de morte no país são as doenças do aparelho circulatório, causas externas (fundamentalmente acidentes de trânsito e homicídios), neoplasias, doenças do aparelho respiratório, doenças infecciosas e parasitárias e afeç̧ões originadas no periodo perinatal ${ }^{153,167}$, variando seu número de ordem de região para região (Tabela 1).

\begin{tabular}{lcccccc}
\hline \multirow{2}{*}{$\begin{array}{c}\text { causas } \\
\text { principais }\end{array}$} & Brasil & Norte & Nordeste & Sudeste & Sul & C.Oeste \\
\cline { 3 - 7 } & & & & & & \\
causas mal definidas & 20.3 & 27.3 & 45.5 & 8.9 & 12.5 & 17.6 \\
causas definidas & 100.0 & 100.0 & 100.0 & 100.0 & 100.0 & 100.0 \\
enferm. do ap. circulatório & 33.3 & 21.7 & 27.4 & 35.7 & 36.8 & 29.3 \\
causas externas & 14.7 & 16.9 & 15.7 & 14.0 & 13.9 & 22.0 \\
neoplasias & 11.4 & 8.5 & 7.8 & 11.7 & 15.2 & 9.6 \\
enferm. do ap. respiratório & 10.3 & 8.3 & 9.5 & 10.9 & 10.4 & 8.5 \\
enferm. infec. e parasit. & 7.8 & 19.5 & 14.3 & 5.7 & 5.1 & 9.8 \\
afecções perinatais & 7.1 & 11.0 & 9.7 & 6.4 & 5.5 & 7.2 \\
outras causas & 15.4 & 14.1 & 15.6 & 15.6 & 13.1 & 13.6 \\
& & & & & & \\
\hline
\end{tabular}

Tabela 1 - Mortalidade proporcional por grupos de causas e regiōes geográficas, Brasil, 1986. Fonte: OPS (1990).

É interessante observar, ainda, a enorme oscilação da freqüência de sinais e sintomas mal definidos de uma região para outra, expressando situações bastante distintas em termos de qualidade e confiabilidade dos dados disponiveis (Tabela 1).

Em relação ao Coeficiente de Mortalidade Infantil (CMI), componente fundamental da transição epidemiológica, registra-se uma queda importante em seus índices globais: de 160 para 82 por mil nascidos vivos entre 1940 e 1980 . Embora tenha sido reduzido à metade, este coeficiente ainda se apresentava muito elevado naquele momento. Entre 1970 e 1990, a tendência deste coeficiente foi a seguinte: declínio intenso e sistemático entre 1977 e 82; interrupção do declínio entre 1983 e 84 e reduções menores, porém contínuas, até 1989. Também neste indicador a heterogeneidade se faz presente (Figura 8). Em 1989, por exemplo, este coeficiente foi de 59, 35 e 92 por mil nascidos vivos no Brasil e nas regiões Sudeste e Nordeste, respectivamente ${ }^{89,182,186}$.

O componente do CMI que sofreu maior redução foi o tardio (após o primeiro mês de vida), variando-se a estrutura das principais causas de óbito em menores de um ano, com diminuição do peso relativo das doenças infecciosas e aumento das causas perinatais $^{152,153}$. 


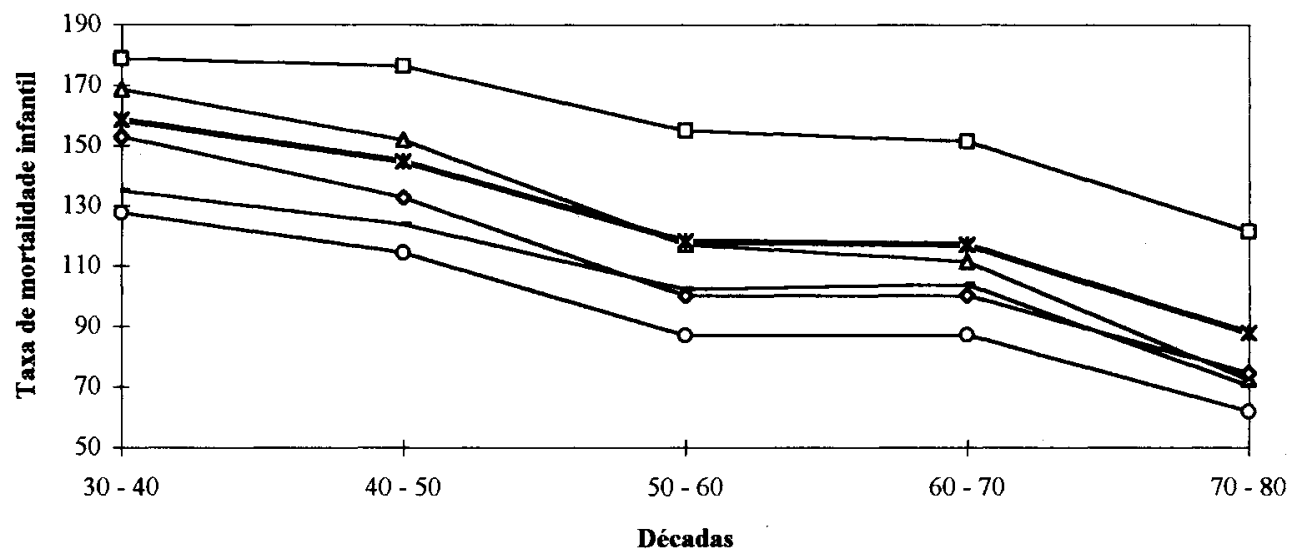

$\triangle-\mathrm{N} \rightarrow \mathrm{I}-\mathrm{NE} \multimap \mathrm{SE} \multimap \mathrm{S}-\mathrm{CO} \rightarrow \mathrm{K}-\mathrm{BR}$

Figura 8 - Coeficiente de mortalidade infantil por região geográfica, Brasil, 1930 - 1980.

Desenhada a partir de dados obtidos em Simões (1992).

Embora os poucos dados disponiveis sobre morbidade não sejam sistemáticos nem tenham representatividade nacional, análises recentes têm reforçado a ocorrência simultânea de agravos crônicos não-transmissiveis e doenças infecciosas, estas últimas com menor letalidade que no passado ${ }^{167,168}$.

\section{Perfil de nutrição}

$\mathrm{Na}$ análise do perfil nutricional de populações dos países não-desenvolvidos, em um dado momento ou período, os problemas enfocados usualmente são a desnutrição energético-protéica em crianças menores de cinco anos e escolares, e os agravos decorrentes de carências especificas como ferro, iodo, vitamina $A$, entre outros ${ }^{13}$. Mais recentemente, também o baixo peso em gestantes e a obesidade, particularmente em adultos, vêm sendo incorporados a esta análise $44,84,86,90$.

As variáveis, indices e indicadores comumente utilizados nesta análise podem ser reunidos em dois grandes grupos: indiretos (de processo) e diretos (de estado).

Do primeiro fazem parte $80,85,90,114$ :

1. aqueles que expressam a situação alimentar, por exemplo: produção de alimentos per capita, disponibilidade de energia per capita.dia ${ }^{-1}$, relação salário mínimo e cesta alimentar básica, horas de trabalho mensais necessárias para obtenção do aporte energético recomendado, história de desmame completo ou parcial aos quatro e seis meses de idade; 
2. os que traduzem as condições socioeconômicas, entre eles: indice de analfabetismo, cobertura de serviços de saneamento básico, indicadores de condições de moradia e de concentração de renda e

3. os que exprimem a situação de saúde e prestação de serviços diretamente ligados a ela, como:

3.1. taxas de mortalidade: infantil, entre 1 e 4 anos, proporção de mortes por doenças mais relevantes para a nutrição - infecções, agravos cardiovasculares - entre outras e

3.2. cobertura vacinal, cobertura de pré-natal, entre outros.

Compõem o segundo grupo ${ }^{73,85,90}$ :

1. aqueles que traduzem o estado nutricional global a partir de observação clínica ou medidas antropométricas, por exemplo: baixo peso ao nascer; os indices massa corporal para idade, massa corporal para estatura e estatura para idade (para menores de cinco anos e escolares), massa corporal para estatura para idade gestacional e índice de massa corporal (massa corporal.estatura ${ }^{-2}$ );

2. aqueles que expressam composição corporal, entre eles: perímetros (braquial, do quadril, da cintura) e dobras cutâneas (triciptal, supra-ilíaca, subescapular) e

3. aqueles que indicam carência específica de nutrientes, como: hemoglobina sérica abaixo de $11 \mathrm{~g} . \mathrm{dl}^{-1}$, hematócrito abaixo de $33 \%$, nível de retinol sérico, presença de Mancha de Bitot $e$ indice de dentes Cariados, Perdidos e/ou Obturados (CPO).

Desta gama de indicadores, serão abordados aqui apenas os antropométricos de estado nutricional global, por serem os mais disponiveis na literatura e por permitirem uma boa noção da evolução geral do perfil de nutrição da população nos últimos anos, como na análise feita para o perfil de mortalidade.

Em linhas gerais, em consonância com as transições epidemiológica e demográfica, estão ocorrendo mudanças alimentares e nutricionais de grande monta nos países nãodesenvolvidos, entre eles o Brasil. Nestes paises, sub e sobrenutrição coexistem, sendo registrada rápida mudança na composição corporal dos adultos, marcado declinio da desnutrição e importantes modificações nos padrões de atividade física e composição da dieta $^{167}$.

Especificamente em relação à evolução do perfil nutricional da população brasilei$\mathrm{ra}$, a análise a seguir será baseada, fundamentalmente, nas duas únicas pesquisas com representatividade nacional sobre nutrição aqui realizadas: o Estudo Nacional da Despesa Familiar (ENDEF), ocorrido em 1974/75, e a Pesquisa Nacional Sobre Saúde e Nutrição (PNSN), feita em $1989^{44,83,86,112}$.

Embora seja possivel fazer uma análise consistente das tendências do perfil nutricional da população brasileira nas últimas duas décadas, cabe ressaltar que não há dados disponiveis para o mapeamento, em nivel nacional, de possiveis oscilações ocorridas ao longo do periodo entre os dois estudos citados. 
Eventualmente, em caráter ilustrativo, serão utilizados resultados de estudos menos amplos, produzidos em amostras probabilísticas de municípios ou na rotina de serviços de saúde.

\section{Peso ao nascer}

O peso ao nascer tem sido cada vez mais valorizado como indicador das condições de saúde e nutrição da população materno-infantil, sendo identificado como o fator isolado mais importante para a sobrevivência infantil, particularmente no primeiro ano de vida ${ }^{200}$.

Embora tenha sido implantado o Sistema de Informações de Nascidos Vivos (SINASC), no ano de 1990, em nivel nacional, não estão ainda disponíveis dados sistemáticos de incidência de Baixo Peso ao Nascer (BPN - ponto de corte: $2500 \mathrm{~g}$ ) para todos os estados e regiões do Brasil.

Estudos recentes têm apontado uma incidência de nascidos de baixo peso em torno de $10 \%$, valor considerado entre médio ( $8 \%$ ) e alto (14\%), segundo proposição internacional ${ }^{115,200}$. Dados parciais do SINASC do município do Rio de Janeiro também indicam incidência próxima a $10 \%{ }^{184}$.

Confirmando a relação deste indicador com as condições familiares de vida, os resultados da PNSN demonstram que a incidência de BPN apresenta claro gradiente por região geográfica (Figura 9), situação urbana ou rural, renda per capita (Figura 10) e grau de instrução da mãe ${ }^{115}$.

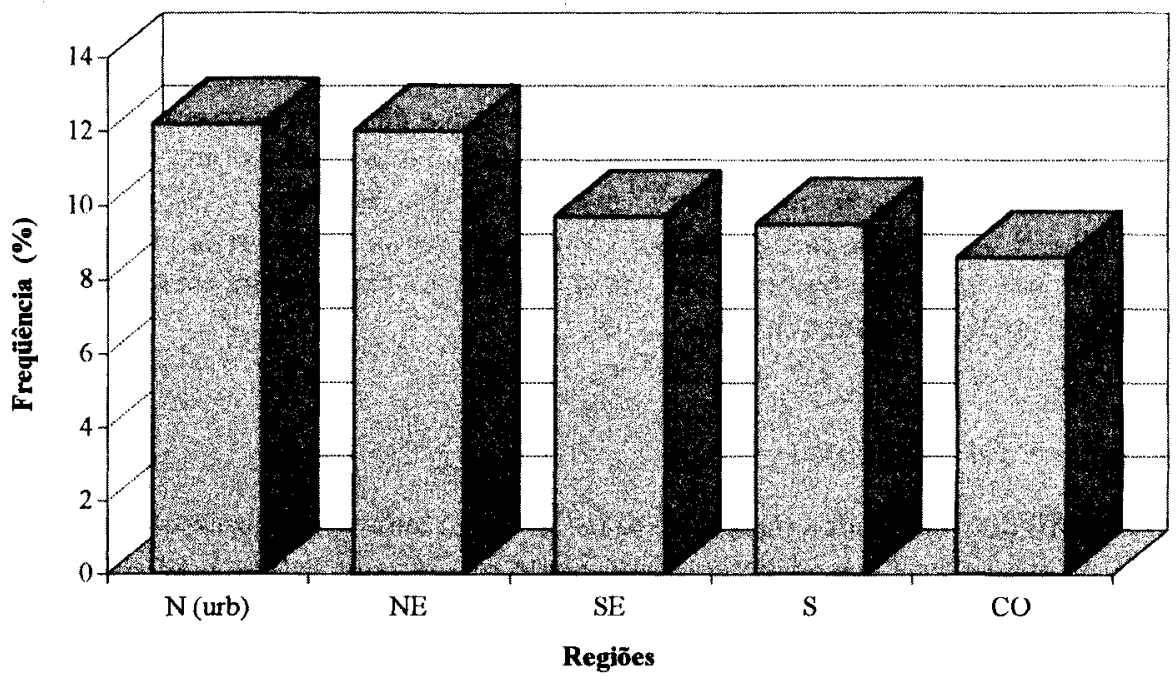

Figura 9 - Baixo peso au nascer por região geográfica, PNSN, 1989.

Desenhada a partir de dados obtidos em Monteiro (1992). 


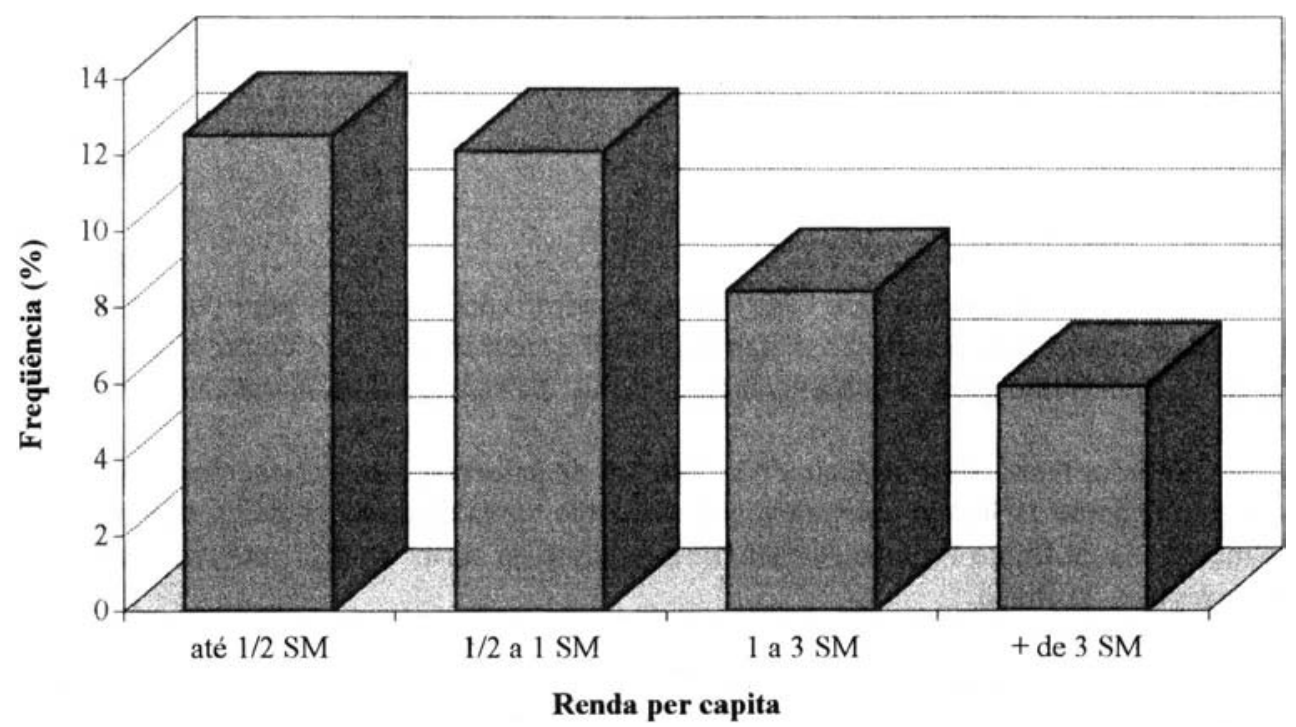

Figura 10 - Baixo peso ao nascer por renda per capita, PNSN, 1989.

Desenhada a partir de dados obtidos em Monteiro (1992).

Além da análise da incidência total de BPN, é importante considerar, também, quais proporções de pré-termos e de nascidos a termo (pequenos para idade gestacional, provavelmente desnutridos intra-útero) a compõem. Nos países desenvolvidos, há uma relação direta entre BPN e prematuridade, enquanto, nos subdesenvolvidos, o retardo de crescimento intra-uterino é o principal responsável pela ocorrência deste evento ${ }^{142}$.

Segundo a PNSN, por exemplo, $23,9 \%$ dos nascidos de baixo peso eram pré-termos. Em contrapartida, dados disponiveis para dois municípios brasileiros mostram situações bastante diversas desta: $42 \%$ em Pelotas ${ }^{200}$ e $43,7 \%$ no Rio de Janeiro (SMS-RJ, dados de 1993, inédito). Como era de se esperar, por estarem em regiōes com melhores indicadores socioeconômicos que a média brasileira, estes municípios apresentam uma situação menos distante daquela dos paises desenvolvidos.

\section{Crescimento de crianças}

O perfil nutricional de crianças menores de cinco anos será expressado por três índices antropométricos: Massa Corporal para Idade (MC/I), que reflete a situação global, não diferenciando os comprometimentos nutricionais atuais ou agudos dos pregressos ou crônicos; Massa Corporal para Estatura (MC/E), que identifica a harmonia do crescimento, sendo comprometido por agravos agudos, e Estatura para Idade $(E / I)$, que examina o crescimento linear, sendo afetado por agravos ao crescimento de caráter crônico, de longa duração $57,116,119,203$. 
Assumiu-se como população de referência a do National Center for Health Statistics, sendo consideradas desnutridas as crianças situadas abaixo de -2 escores $Z^{141,148,206}$.

Quanto ao indicador MC/I, observou-se, entre 1975 (ENDEF) e 1989 (PNSN), uma redução importante da prevalência de crianças abaixo do ponto de corte estipulado: de 18,4 para $7,1 \%$, ou seja, uma queda de mais de $60 \%$ para o grupo etário em geral, sendo ainda maior para a faixa acima de 24 meses (Figura 11). Houve uma redução também expressiva (53\%) em números absolutos: em 1975, o contingente de crianças desnutridas era de 2.222.843, enquanto, em 1989, era de $1.167 .347^{112}$.

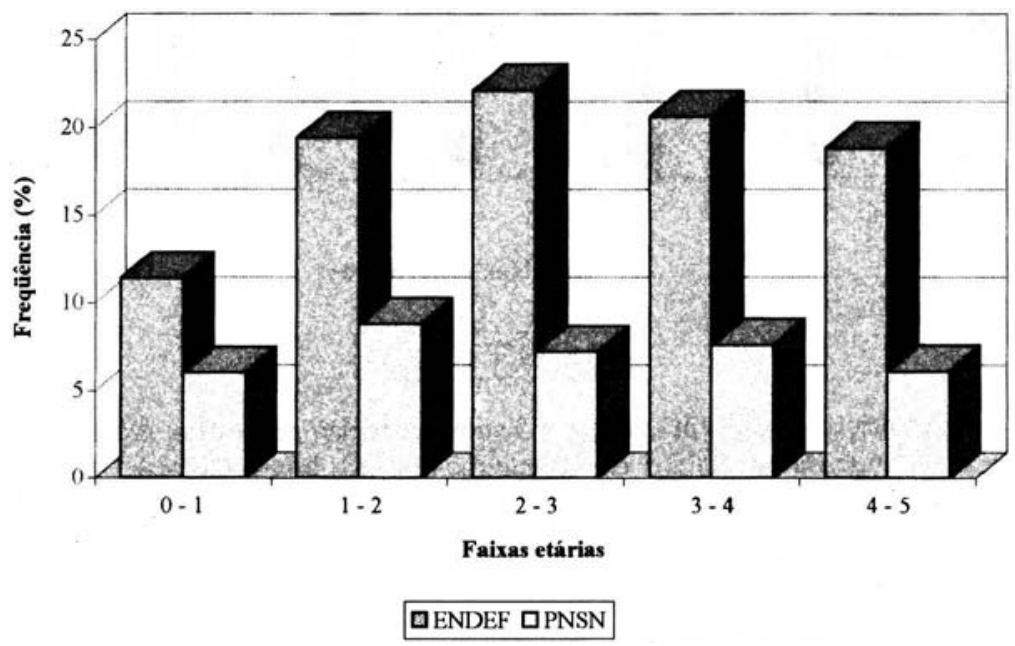

Figura 11 - Desnutrição (MC/I) em crianças < 5 anos por faixa etária, ENDEF/PNSN.

Desenhada a partir de dados obtidos em Monteiro, Benicio, Iunes, Gouveia, Taddei \& Cardoso (1993).

Puderam ser observados progressos importantes em todas as regiões geográficas, nos meios urbano e rural e nas diversas faixas de renda, sendo proporcionalmente mais significativos no Centro-Sul (Figura 12), nos estratos de renda mais altos (Figura 14) e no meio urbano para o pais como um todo (Figura 13). As regiões Sudeste e Sul apresentaram quedas semelhantes tanto no meio rural como urbano. Em linhas gerais, portanto, aumentaram os diferenciais geográficos, urbano/rural e socioeconômicos ${ }^{83,112}$.

Os resultados encontrados na PNSN para os indices $\mathrm{MC} / \mathrm{E}$ indicam que, no Brasil, a desnutrição aguda é irrelevante em termos coletivos. Abaixo de $-2 \mathrm{Z}$ escores encontram-se cerca de $2 \%$ das crianças menores de cinco anos em todas as regiões geográficas e faixas de renda. Esta freqüência é semelhante à da população de referência ${ }^{111}$.

Já em relação ao indice $\mathrm{E} / \mathrm{I}$, quando comparados os dois estudos, foi registrado, para o Brasil como um todo, um aumento da estatura não só entre as crianças menores de cinco anos, mas também entre escolares e adolescentes ${ }^{83}$.

Ainda assim, a desnutrição crônica é bastante relevante: $15,4 \%$ das crianças meno- 


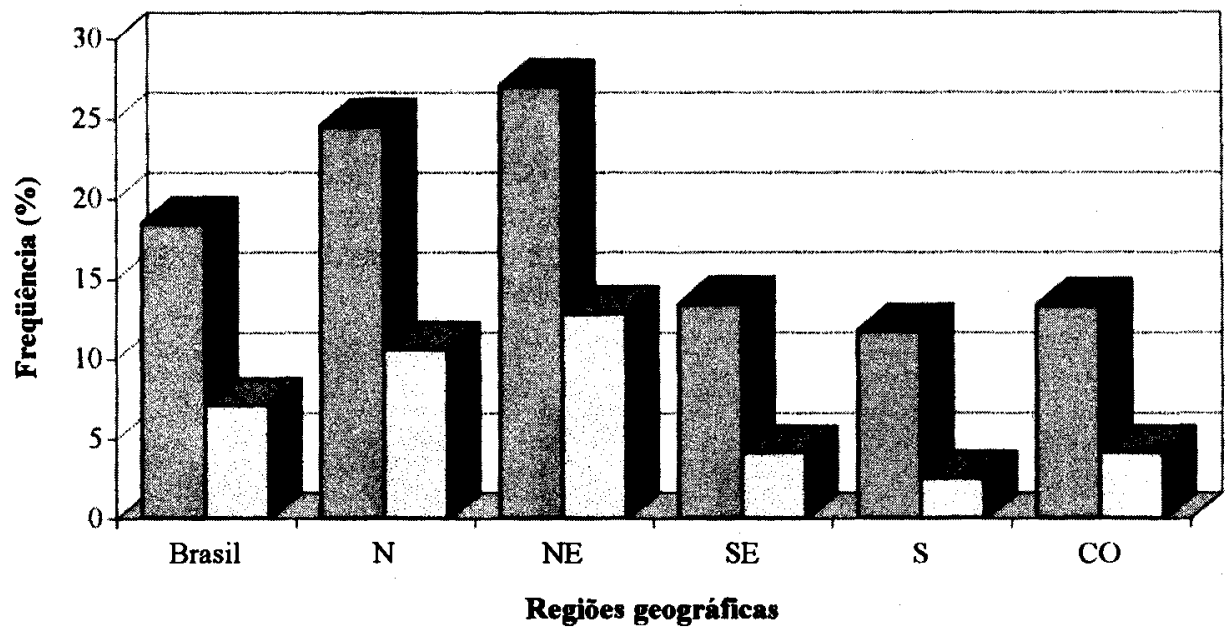

\section{OENDEF DPNSN}

Figura 12 - Desnutrição (MC/I) em crianças < 5 anos por região geográfica, ENDEF/PNSN. Desenhada a partir de dados obtidos em Monteiro, Benício, Iunes, Gouveia, Taddei \& Cardoso (1993).

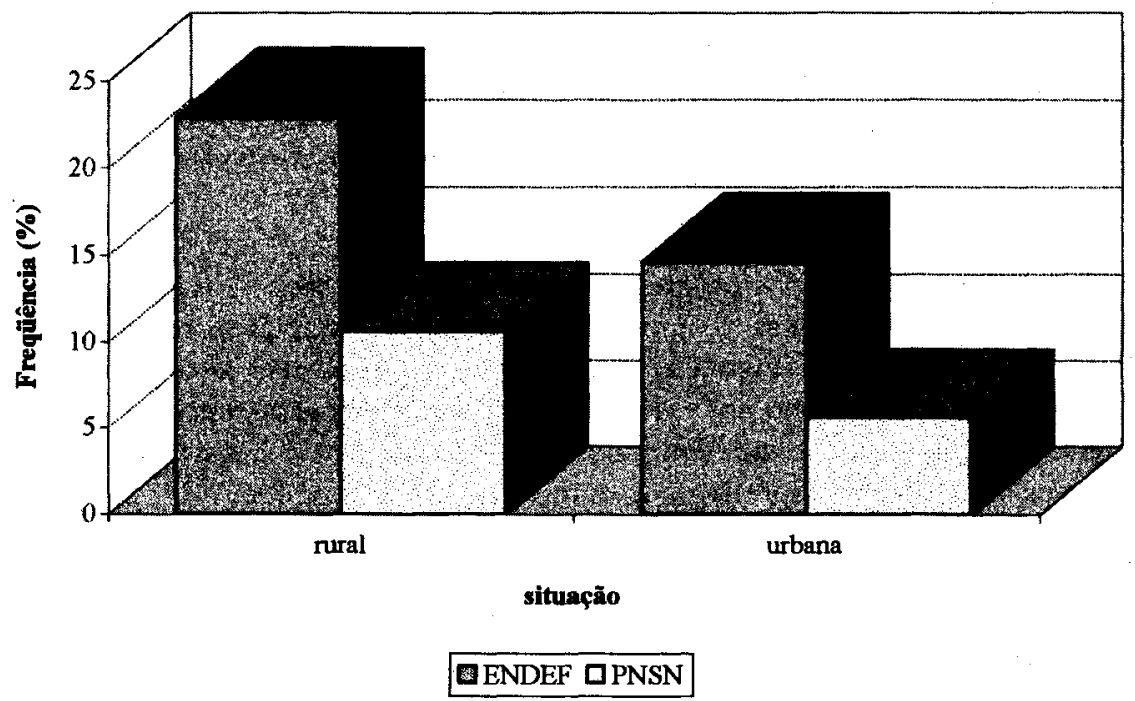

Figura 13 - Desnutrição (MC/I) em crianças < 5 anos por situação rural ou urbana, ENDEF/PNSN. Desenhada a partir de dados obtidos em Monteiro, Benício, Iunes, Gouveia, Taddei \& Cardoso (1993). 


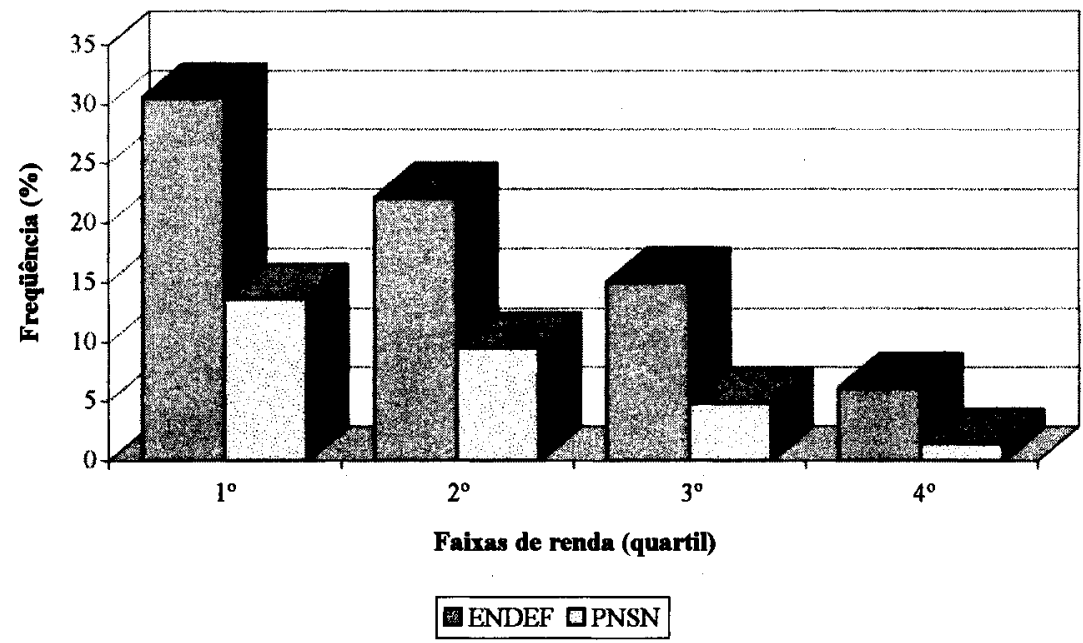

Figura 14 - Desnutrição (MC/I) em crianças < 5 anos por faixa de renda, ENDEF/PNSN.

Desenhada a partir de dados obtidos em Monteiro, Benício, Iunes, Gouveia, Taddei \& Cardoso (1993).

res de cinco anos foram diagnosticadas como tendo baixa estatura, estando presentes, também aqui, importantes diferenciais entre as diversas regiōes geográficas (Figura 15), meios urbano e rural (idem) e faixas de renda ${ }^{108,111}$. Vale destacar que a maior prevalência de desnutrição crônica nas regiōes Norte e Nordeste é decorrência de dois fatores: o menor nível de renda das familias que aí vivem em relação às do Centro-Sul e a maior freqüência de baixa estatura mesmo em estratos de renda iguais ${ }^{107,108}$.

Lançando mão de estudos menos amplos, complementares ao ENDEF e ao PNSN, Iunes \& Monteiro (1993) sugerem que, em relação à evolução do perfil nutricional infantil, o periodo de 1970 a 1989 pode ser dividido em três subperíodos: o primeiro, de estagnação do estado nutricional (1970 a 1975), o segundo, de ganhos importantes e continuados (1975 a 1982) e o terceiro, de ganhos moderados e descontínuos (1982 a 1989).

Comparado a outros países não-desenvolvidos da África, Ásia, América Latina e Oceania, o Brasil se encontra no grupo de baixa prevalência de desnutrição infantil, com frequiências globais menores que $10 \%$ para o índice $\mathrm{MC} / \mathrm{I}$; inferiores a $4 \%$ em relação a MC/E e abaixo de $20 \%$ para E/I. Em termos absolutos, entretanto, encontra-se em situação intermediária ${ }^{49}$.

Entre os principais determinantes destes avanços globais no perfil nutricional da população infantil estão: queda da fecundidade, urbanização, redução da prevalência de pessoas abaixo da linha de pobreza absoluta, aumento das coberturas vacinal e de serviços de saneamento básico, ampliação da rede básica de assistência e das práticas de atenção primária à saúde, aumento da proporção alfabetizada e com escolaridade elementar na população (em especial as mulheres) e ampliação dos meios de comunicação de mas$\mathrm{sa}^{86,89,112}$. 


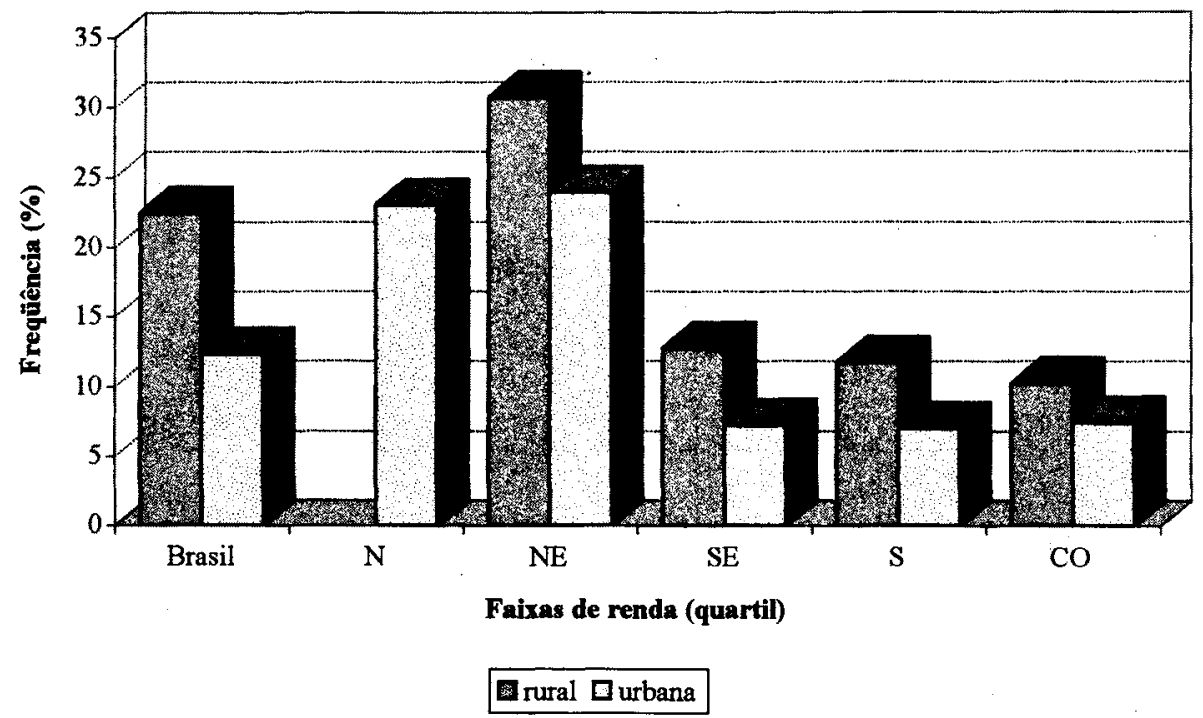

Figura 15 - Desnutrição (E/I) em crianças < 5 anos por região geográfica e situação rural ou urbana, ENDEF/PNSN).

Desenhada a partir de dados obtidos em Monteiro, Benício, \& Gouveia (1992).

Além disto, parece ainda ser positivo o balanço econômico global do periodo 1975-1989, apesar da grave crise econômica deflagrada na década de 80, com aprofundamento da concentração de renda, aumento estupendo da inflação, deterioração dos níveis de renda da população e recrudescimento da pobreza absoluta.

Observe-se, portanto, que o que garantiu os avanços no estado nutricional da população infantil não foi a melhoria dos niveis de renda em si, mas a ampliação do entitlement, ou oportunidade de acesso, definida por Drèze \& Sen (1989, p. 23) como "o conjunto de bens e serviços que podem ser adquiridos através do uso de vários canais legais de aquisição abertos para aquela pessoa" (tradução transcrita de Iunes \& Monteiro, 1993, p. 55).

É como se os ganhos da década de 70, principalmente nos cinco primeiros anos, tivessem uma inércia suficiente para se manterem ao longo do periodo recessivo que se seguiu. Nada garante, no entanto, que este perfil não se reverta, caso a deterioração dos niveis de renda se mantenha.

Vale lembrar que os avanços globais da população infantil se deram de forma heterogênea nas diversas regiões geográficas, aprofundando-se o gradiente entre elas (Norte/Nordeste versus Sul/Sudeste/Centro-Oeste). Isto reflete os investimentos também heterogêneos, nestas regiōes, em termos de saneamento básico, cobertura vacinal e de serviços de saúde, entre outros. 


\section{Situação nutricional de adultos}

Para a análise do perfil nutricional de adultos, aqui assumidos como indivíduos com 18 anos e mais, será usado o indice de massa corporal (IMC), que é a razão entre a massa corporal (em quilogramas) e o quadrado da estatura (em metros). Embora apresente limitações, este ainda é o índice que, através de medidas antropométricas globais bastante difundidas, melhor reflete indiretamente a composição corporal de adultos ${ }^{2}$.

As situações de baixo peso, normalidade, sobrepeso e obesidade foram definidas como sendo as seguintes faixas de IMC, respectivamente: $<20 ; 20-24,9 ; 25-29,9 \mathrm{e}=>30^{44}$.

Os resultados da PNSN3,43,44 indicam que a prevalência de baixo peso é semelhante, em torno de $16 \%$, entre homens e mulheres (Figura 16), concentrando-se nas faixas etárias extremas (Figura 17). O diferencial de renda, pouco relevante entre os jovens, intensifica-se a cada faixa etária, atingindo os valores mais altos entre os idosos. Ou seja, os individuos com 65 anos e mais, com renda mais baixa, apresentam prevalências superiores de baixo peso. Este diferencial também se faz presente entre as regiōes geográficas e entre os meios rural e urbano, com freqüências mais altas no Nordeste e no meio rural.

Em relação ao excesso de peso, os achados são bastante diferentes: $32 \%$ da população adulta apresentam sobrepeso ou obesidade: entre os homens, os percentuais estão em torno de 27\%; entre as mulheres, 38\% (Figura 16). De modo geral, as discrepâncias entre os gêneros, com maiores prevalências de sobrepeso e obesidade sistemáticas entre as mulheres, aparecem independentemente da renda e situação de moradia, sendo maior no meio rural e nas rendas mais baixas.

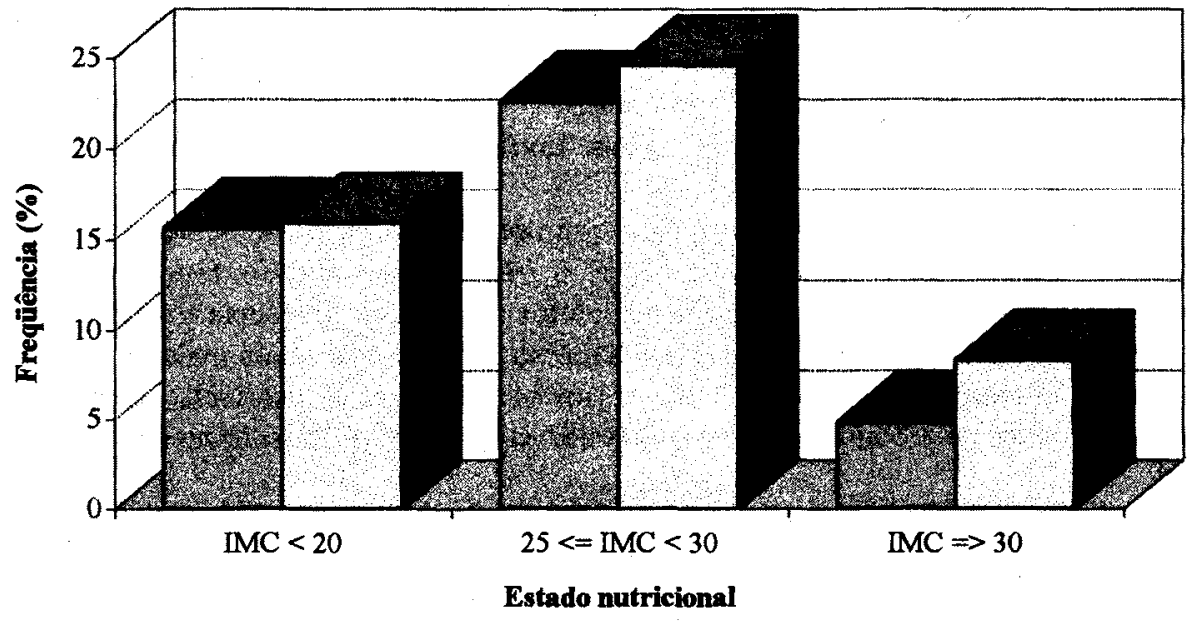

Womens mulheres

Figura 16 - Baixo peso, sobrepeso e obesidade em adultos por gênero, PNSN, 1989. Desenhada a partir de dados obtidos em Coitinho, Leão, Recine \& Sichieri (1991). 


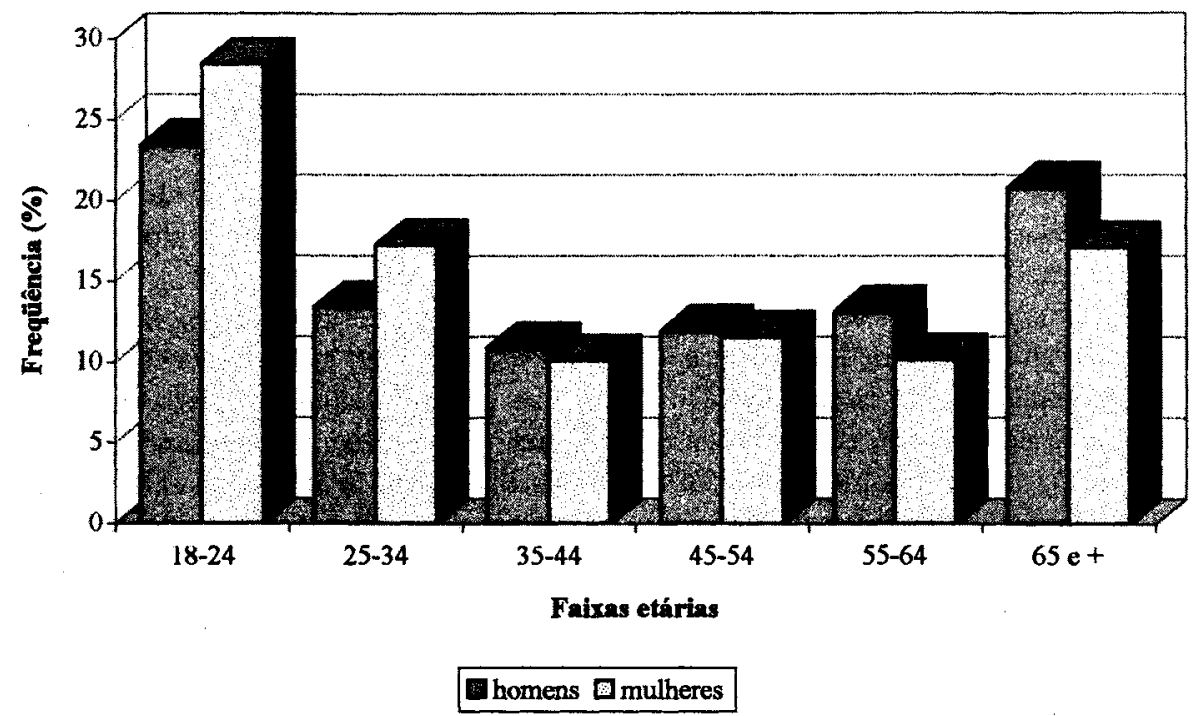

Figura 17 - Baixo peso em adultos (IMC < 20) por gênero, PNSN, 1989.

Desenhada a partir de dados obtidos em Coitinho, Leão, Recine \& Sichieri (1991).

Estas prevalências aumentam até a faixa de 45 a 54 anos, quando então, nos homens, decrescem um pouco e, nas mulheres, mantêm-se relativamente estáveis (Figura 18). Embora haja uma tendência semelhante em relação às faixas etárias nos diferentes níveis de renda, observa-se um importante gradiente entre os homens: $16 \%$ de excesso de peso nos mais pobres e $44 \%$ nos mais ricos. Entre as mulheres, um diferencial menos marcado: 31 e $41 \%$, respectivamente.

Todas as regiões geográficas apresentam prevalências importantes de sobrepeso e obesidade, variando de $24 \%$, no Nordeste, a $38,7 \%$, no Sul, havendo, também aqui, um claro gradiente entre elas. Em números absolutos, o Sudeste apresenta a pior situação: mais de 10 milhões de adultos apresentam excesso de peso, dos quais mais de 3 milhões são obesos. O Nordeste e o Sul, embora sejam os extremos no gradiente de freqüência percentual, apresentam contingentes semelhantes, cerca de 5 milhões, nesta situação nutricional.

Quanto à situação de moradia, registram-se valores ligeiramente maiores no meio urbano para ambos os gêneros e todas as faixas de renda, exceto para as mulheres de renda mais alta. Nelas a tendência se inverte: as maiores prevalências ocorrem entre as do meio rural.

Comparando-se com paises desenvolvidos, o Brasil apresenta menos excesso de peso e, curiosamente, maior prevalência de obesidade entre as mulheres, superando, por exemplo, o Canadá, o Reino Unido, a Holanda e a Austrália.

Complementando esta constatação, Anjos, Silva, Serrão \& Silva (1992) observa- 


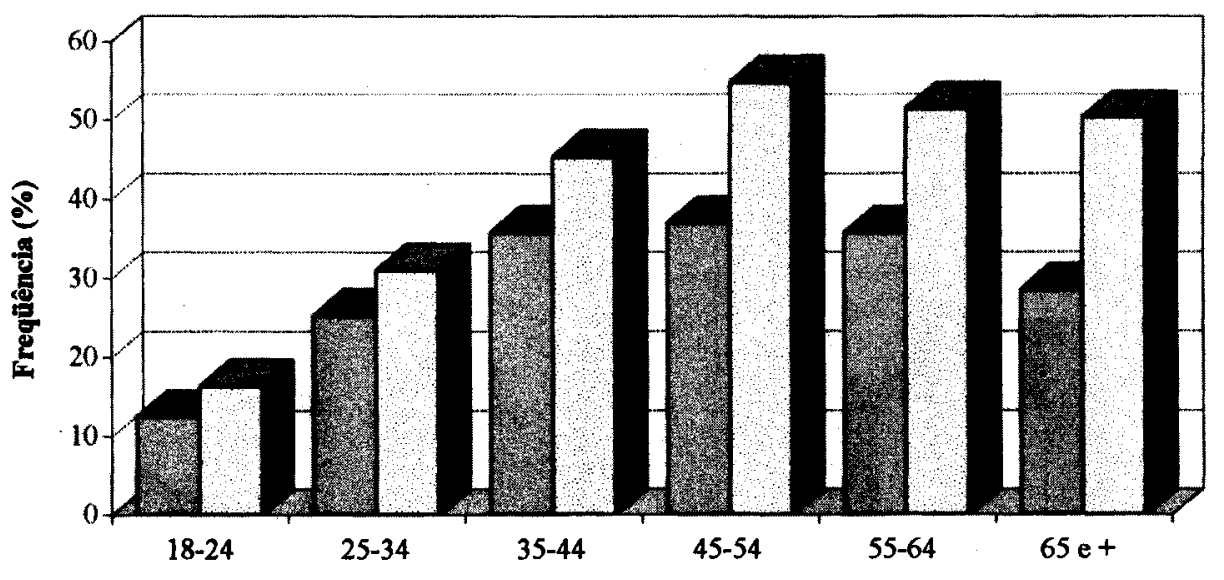

Faixas etárias

\section{国 homens $\mathrm{D}$ mulheres}

Figura 18 - Excesso de peso en adultos (IMC = > 25) por gênero, PNSN, 1989.

Desenhada a partir de dados obtidos em Coitinho, Leão, Recine \& Sichieri (1991).

ram que mais de $50 \%$ das mulheres faveladas atendidas em determinado serviço de atenção primária à saúde apresentaram excesso de peso. Este se faz presente, em média, entre os 30 e $\mathbf{4 0}$ anos, enquanto, entre as norueguesas, este ocorre entre os $\mathbf{4 0}$ e $\mathbf{5 0}$ anos. Embora sejam pontuais, estes dados levantam um questionamento relevante para a análise da situação nutricional da população brasileira, qual seja o da precocidade do aparecimento do excesso de peso, ao menos entre as mulheres.

Em linhas gerais, tendo sido ajustada a estrutura etária de 1989 para aquela vigente em 1974, os resultados da PNSN, quando comparados aos do ENDEF, apontam para queda da prevalência de baixo peso e aumento do sobrepeso e obesidade para ambos os gêneros, mantendo-se semelhantes as freqüências de individuos com estado nutricional adequado (Figura 19). Estes achados são semelhantes aos de outros países da América Latina, nos quais o excesso de peso tem também aumentado ${ }^{153}$.

Os fatores que parecem explicar esta mudança de perfil são, entre outros: envelhecimento da população; substituição de alimentos ricos em proteinas e vitaminas por outros ricos em gorduras e carboidratos, sem aumento do consumo global de alimentos; possivel diminuição dos niveis de gasto energético, seja por ampliação das ocupações do setor de serviços, e/ou por mudança na forma de se viver, com aumento do sedentarismo, e/ou, ainda, por redução da ocorrência de doenças infecciosas e da espoliação orgânica dela decorrente ${ }^{44}$. No entanto, são necessários outros estudos para que se elucidem, com mais profundidade, os determinantes do perfil nutricional dos adultos brasileiros. 


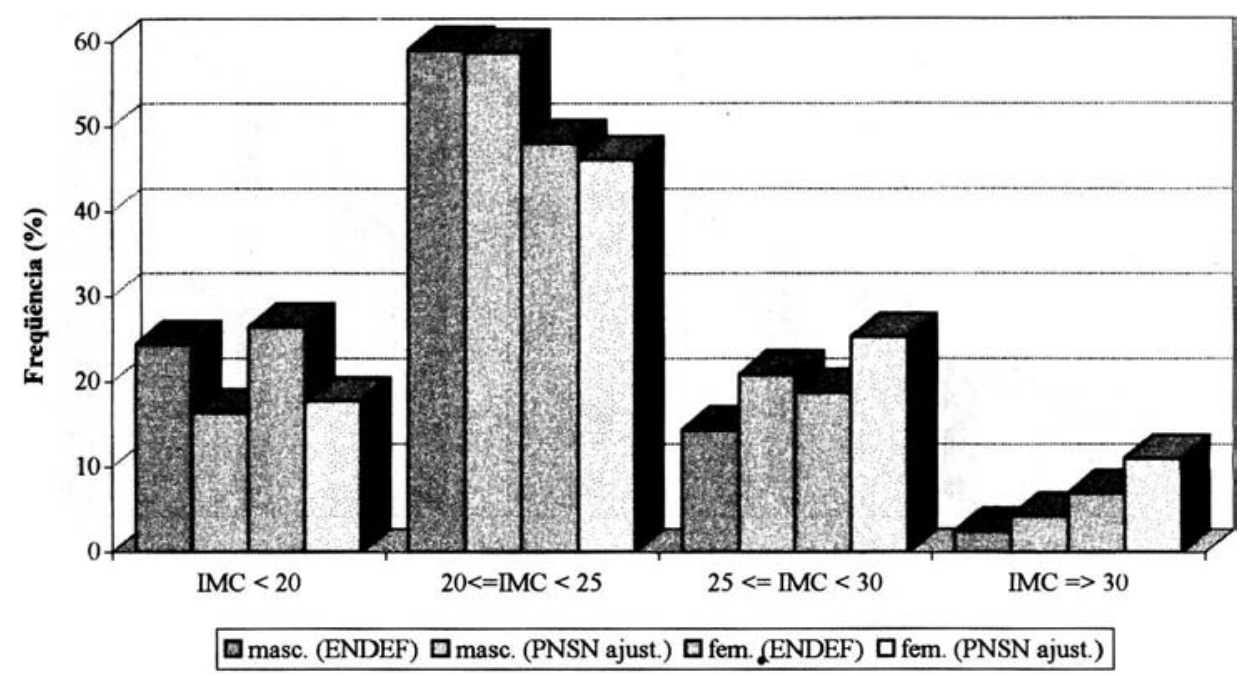

Figura 19 - Estado nutricional de adultos por gênero, ENDEF/PNSN, ajustado por idade. Desenhada a partir de dados obtidos em Coitinho, Leão, Recine \& Sichieri (1991).

\section{Situação nutricional de gestantes}

É consenso, hoje, que o estado nutricional da gestante é fator fundamental para a saúde dela própria e do bebê e que, particularmente nos paises não-desenvolvidos, as mulheres grávidas representam um grupo bastante vulnerável nutricionalmente $57,150,152,200$.

No entanto, em muitos paises, entre eles o Brasil, não há informações que espelhem nacionalmente a situação nutricional deste grupo. Os poucos resultados disponiveis são os produzidos pelo sISVAN na rede pública de assistência à saúde de alguns municípios, sendo utilizado o índice massa corporal para estatura para idade gestacional através do gráfico de Rosso $(1985)^{173}$. Este instrumento foi preconizado pelo Ministério da Saúde na segunda metade da década de 80 sem ter sofrido prévia validação para a população brasileira. Estudo multicêntrico desenvolvido em seguida demonstrou que a curva então recomendada apresenta especificidade e valor preditivo positivo baixos ${ }^{187}$. Portanto, os dados apresentados a seguir devem ser encarados com cautela.

Em Fortaleza, por exemplo, os consolidados de 1991 indicaram que, das gestantes atendidas, $39,6 \%$ apresentaram baixo peso e $14,5 \%$ sobrepeso em 1991 e $43 \%$ e $15 \%$, respectivamente, no primeiro semestre de $1992^{87,88}$. Valores semelhantes foram encontrados para o baixo peso em Pernambuco: no período de maio a agosto, sua prevalência oscilou entre 37 e $40 \% 64$.

Já na rede municipal de saúde do Rio de Janeiro, as prevalências de baixo peso e sobrepeso foram, respectivamente, de 39 e $17 \%$ em $1991^{55}$ e de 32 e $21 \%$ em $1993^{56}$. 
Estes resultados apontam para uma prevalência bastante relevante de baixo peso nas diversas realidades e de sobrepeso, principalmente no Rio de Janeiro. É fato que eles expressam o perfil da clientela que freqüenta os serviços públicos de saúde, não podendo, portanto, ser extrapolados para toda população gestante brasileira. De qualquer modo, apontam para o fato de que mais de $50 \%$ da clientela gestante atendida está fora da faixa de ganho adequado de peso, reforçando a necessidade de um mapeamento mais criterioso e representativo que subsidie uma análise ampla deste perfil. 


\section{Vigilância epidemiológica e atenção à saúde}

Neste capítulo será revisado material bibliográfico de dois campos de atuação da rede pública de assistência: (a) a Vigilância Epidemiológica (VE), que serviu como base para a proposição e estruturação do SISVAN ${ }^{63,102,154}$, e (b) as atividades inseridas nos programas de atenção integral, apontadas, mais recentemente, como canal fundamental para a viabilização do SISvan nos serviços de saúde ${ }^{10,16,17,57}$.

O intuito desta revisão, mais que avaliar a situação atual destes dois campos de atuação, é delinear que práticas e concepções embasaram seu surgimento e quais ações são hoje preconizadas em cada um deles, a fim de subsidiar a discussão realizada no capítulo 4.

\section{Vigilância Epidemiológica}

Podem ser apontadas como primórdios da VE as práticas de quarentena, existentes desde a antigüidade, que tinham como objetivo a identificação e $o$ isolamento de pessoas com doenças transmissiveis com vistas ao controle da propagação das mesmas ${ }^{175,204}$.

Sua conformação, no entanto, perpassou vários séculos, sendo necessário, para tal, uma estruturação mínima dos sistemas de saúde, o que pressupunha a existência de um governo estável; algum tipo de sistema classificatório de síndromes, sintomas e doenças que fosse largamente conhecido e, também, uma forma mais organizada de medir, contar e somar eventos, iniciada no século XVII ${ }^{58}$.

O fim do século XVIII e o século XIX foram marcados por processos, entre outros, como o da Revolução Industrial, com crescimento das cidades e aglomeração dos individuos, levando à grande disseminação de doenças; a expansão do colonialismo, introduzindo na Europa enfermidades não conhecidas até então e as descobertas no campo da microbiologia. Tudo isto favoreceu uma maior estruturação das práticas que, na primeira metade do século $\mathrm{XX}$, compuseram campanhas e programas verticalizados de controle de doenças transmissiveis especificas, que funcionavam de forma isolada e em lugares ou situações determinados, como portos ou construção de estradas ${ }^{50,149,204}$.

Em 1955, o então Centro de Doenças Transmissiveis (hoje Centro de Controle de Doenças) dos Estados Unidos da América propôs uma nova conotação para a VE: a de um 
conjunto de atividades dirigidas ao conhecimento de uma determinada enfermidade (e não mais vigilância do indivíduo) na população $50,66,172$.

Ainda neste periodo, o grande avanço tecnológico alcançado após a II Guerra Mundial acarretou a formulação da idéia de erradicação de doenças. Dela derivaram programas, em especial o de erradicação da variola, cuja experiência marcou decisivamente a metodologia das práticas de VE adotadas até hoje ${ }^{175}$.

O controle efetivo de algumas enfermidades transmissiveis, através de práticas como a imunização; o aumento do peso relativo da mortalidade por doenças crônicas nãotransmissiveis e outros agravos e a perspectiva de sistema para a VE, proposta no modelo de atenção primária - comentado no item a seguir - levaram à ampliação do conceito de VE.

Este conceito, nos últimos anos, tem recebido inúmeras definições que trazem em comum as idéias de estado de constante atenção, de obtenção de informações necessárias e de realização de investigações para avaliar a situação de saúde da população e suas tendências ${ }^{66}$. No entanto, nem todas contemplam como atribuição da VE a adoção de medidas de controle, circunscrevendo seu papel ao fornecimento de informações contínuas 50,198 .

Assumindo-se que a execução de ações de controle componha o rol de atividades da VE, esta pode ser definida como um conjunto de atividades regulares e contínuas de observação, investigação e análise de parâmetros de saúde e ambientais, geralmente utilizando-se métodos escolhidos por sua praticidade, uniformidade e rapidez de obtenção, mais do que sua acurácia ${ }^{198}$. Deve ser capaz de medir a magnitude de um agravo em uma população, estabelecendo sua incidência e prevalência, identificar grupos e área sob risco e prever ou detectar possiveis mudanças nas situaçōes ambientais e de saúde da população. Tem como finalidades principais recomendar e adotar, oportunamente, medidas que levem à prevenção e controle de agravos, bem como avaliar a pertinência destas medidas 58,120 .

Uma vez definido o que será diagnosticado como "caso", determinados os indicadores a serem usados e os consolidados a serem produzidos, as atividades que compõem a VE são $58,66,140$ :

1. coleta de dados: abarca, fundamentalmente, a seleção dos dados necessários; a elaboração de formulários padronizados, contendo somente as informações essenciais, devendo ser claros, simples e sem ambigüidade; estabelecimento de canais de envio dos mesmos e de normas de periodicidade deste envio; identificação de fontes de informação; realização de investigações especiais para melhor configuração do quadro em estudo e reunião dos dados necessários para a coordenação do funcionamento do sistema de informações;

2. processamento, análise e interpretação: engloba o cálculo de taxas e proporções, feitura de tabelas e gráficos, fixação de padrões de comparação, análise da informação produzida e elaboração de informes que apresentem esta análise; 
3. divulgação das informações: envolve a comunicação dos achados e a indicação de medidas de controle a instâncias de decisão, bem como a publicação de boletins ou similares e sua divulgação para os serviços de saúde e outros interessados;

4. recomendações: dizem respeito ao estabelecimento e atualização de normas para os procedimentos, ações de controle e avaliação destas últimas, $\mathrm{e}$

5. açōes de controle: contemplam a proteção dos susceptiveis, interferência em um surto, orientação e tratamento dos casos, acompanhamento do cumprimento de normas de ações que extrapolem a alçada dos organismos de vigilância.

Esta definição de VE está vinculada a uma compreensão ampliada - nem sempre consensual $^{34,193}$ - das potencialidades da epidemiologia, e em particular da vigilância epidemiológica, no planejamento de ações de saúde e organização de serviços.

Inúmeros autores têm apontado a aplicabilidade de sua metodologia, entre outros: no acompanhamento sistemático de agravos não-infecciosos e determinantes do processo saúde-doença ${ }^{25,58,190}$; na avaliação de procedimentos preventivos, terapêuticos ou diagnósticos 58,202 ; no mapeamento do perfil global de saúde para a elaboração de políticas de saúde ${ }^{52,82,199}$; no seguimento de indicadores de eqüidade na prestação de serviços de saú$\mathrm{de}^{189}$; na avaliação dos resultados de programas de saúde $\mathbf{~}^{33}$.

Outros autores, entretanto, mais recentemente, vêm afirmando ser inadequado o uso do termo "epidemiológica" para caracterizar uma prática ampliada de vigilância em saúde, já que discordam de que as dimensões de controle e pesquisa componham as ações da mesma. Sugerem como sendo mais apropriado o termo "vigilância em saúde pública" e propõem como sendo seus objetivos os seguintes: (a) descrever o padrão atual de ocorrência de doenças e ligá-lo à ação em saúde pública; (b) aumentar o conhecimento da história natural e epidemiologia das doenças e (c) fornecer informação e dados de base ("baseline data" $^{50}$.

No entanto, apesar de intensa produção acadêmica sobre a pertinência da aplicação do instrumental epidemiológico nas frentes citadas acima, de algumas experiências localizadas destas proposições ${ }^{202} \mathrm{e}$, ainda, à revelia da polêmica sobre como melhor caracterizar a prática ampliada de vigilância, a VE continua, em boa parte dos paises não-desenvolvidos, restrita ao controle de um grupo de doenças infecciosas ${ }^{156}$. Além disto, as tentativas de estruturação de sistemas de vigilância em saúde são ainda muito fragmentadas ${ }^{191}$.

No Brasil, a experiência de VE seguiu, em linhas gerais, um processo semelhante ao descrito acima. Inicialmente vinculou-se à vigilância dos portos para o controle de epidemias, sendo organizados, com o passar dos anos, vários programas verticalizados e independentes uns dos outros ${ }^{175}$.

Na década de 70, o Ministério da Saúde instituiu o Sistema Nacional de Vigilância Epidemiológica que, em tese, procurou acompanhar as tendências internacionais de ampliação das dimensões da VE, mas manteve-se restrito às doenças transmissiveis. Mesmo estruturados dentro de um sistema, os programas continuaram a ser gerenciados por instituições diferentes, mantendo-se pouca ou nenhuma articulação entre $\mathbf{s i}^{159,170}$.

Nos anos 80 , o investimento no controle das doenças imunopreveniveis, através de 
atividades como campanhas de vacinação e produção nacional de vacinas, contribuiu para uma melhor estruturação e articulação (ainda tênue) das práticas de VE ${ }^{175}$. Nesta década, eram objeto de controle pela VE as seguintes doenças: tuberculose, hanseníase, poliomielite, sarampo, tétano, coqueluche, difteria, meningites, raiva, doenças sexualmente transmissiveis e febre tifóide. Já as endemias estavam sujeitas a ações verticalizadas da então Superintendência de Campanhas de Saúde Pública ${ }^{120}$. Até este período, portanto, o sistema de vigilância epidemiológica, restrito às doenças transmissiveis, não abarcou os agravos que passaram a ser relevantes com a mudança do perfil de morbimortalidade da população brasileira, comentada no capitulo anterior ${ }^{37}$.

A década de $\mathbf{8 0}$ foi, também, marcada por intensa produção científica sobre os paradigmas e as perspectivas da epidemiologia, assim como por inúmeros eventos e debates sobre o papel desta área de conhecimento e, como desdobramento, da VE, na elaboração e avaliação das políticas de saúde. Estes contribuíram decisivamente para a reformulação da inserção desta área e deste campo de práticas quando da estruturação do Sistema Único de Saúde (sUS), a partir da promulgação da Constituição Federal e da Lei Orgânica da Saú-

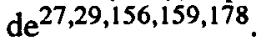

Entre as modificações ocorridas em termos de institucionalização da epidemiologia e da VE no processo de estruturação do sus, merecem destaque as seguin-

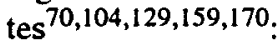

1. o reconhecimento de que a não utilização da epidemiologia no planejamento em saúde se deve menos ao desconhecimento de sua importância e à insuficiência de quadros técnicos e mais ao fato de sua racionalidade competir com outras lógicas de planificação;

2. a ampliação do conceito de $\mathrm{VE}$, que não se restringe mais a doenças transmissiveis e assume a adoção de medidas de controle também como atribuição sua;

3. a incorporação dos municípios como instâncias também responsáveis pela viabilização do Sistema Nacional de Vigilância Epidemiológica, descentralizando-se, portanto, sua gerência;

4. o investimento na revisão do sistema de informações em saúde - tradicionalmente fragmentado em inúmeros subsistemas que funcionaram de maneira paralela e descoordenada - com o intuito de evitar superposições desnecessárias e aumentar a utilidade das informações geradas;

5. a retomada da divulgação, pelo Ministério da Saúde, de informações epidemiológicas, agora reunidas numa única publicação periódica, o Informe Epidemiológico do sus;

6. a criação do Centro Nacional de Epidemiologia (CENEPI), instância de referência técnica que deve integrar-se aos demais órgãos do sus e articular-se com instituições acadêmicas. Tem como atribuições a promoção e a disseminação do uso da metodologia epidemiológica em todos os niveis do sUs, subsidiando a formulação e implementação de politicas, a organização dos serviços e as ações de saúde. Como áreas básicas de sua atuação figuram a vigilância e controle de doenças e agravos, avaliação e acompanhamento das condições de vida e saúde e promoção do uso da epidemiologia; 
7. a estruturação do Sistema de Informações de Nascidos Vivos (SINASC), iniciada em 1990, através de um trabalho conjunto do CENEPI com as coordenações de epidemiologia de diversos estados e municípios;

8. na lista das doenças que são objeto de controle pela VE, a inclusão de agravos como a AIDS e as doenças ocupacionais, e.g., acidentes de trabalho que levam a óbito ou que necessitam de internação médica de emergência, intoxicações por agrotóxico e outras intoxicações exógenas, dermatoses ocupacionais, doenças hiperbáricas e surdez de origem ocupacional e

9. na discussão da reforma administrativa do MS, a proposição de uma subsecretaria de vigilância dentro da secretaria de atenção à saúde, que reuniria os departamentos de vigilância de agravos à saúde (responsável por doenças transmissíveis e não-transmissiveis, crônico-degenerativas, saúde bucal e do trabalhador), de vigilância de produtos, processos e serviços, de vigilância nutricional, de saneamento e meio ambiente e de operações (responsável pelos serviços de portos, aeroportos e fronteiras e pelas atividades a serem descentralizadas na área de doenças endêmicas e saneamento).

Há, no entanto, uma distância muito grande entre esta gama de mudanças - que apontam a metodologia epidemiológica como instrumento para definição e avaliação de políticas e programas - e a prática de VE já instituida ${ }^{38}$. Esta tem tido um desempenho bastante heterogêneo, comumente precário, nas diversas unidades de saúde. Além disto, com sua prática ainda restrita, em geral, ao acompanhamento de determinados agravos transmissiveis, está longe de apresentar uma integração concreta com as práticas de atenção integral, estruturadas nos diversos programas preconizados pelo MS, comentados no item a seguir ${ }^{34,175}$.

Quanto aos agravos não-transmissiveis, embora estejam previstos como objeto de controle da VE, têm ainda sido alvo de ações bastante dispersas, restritas a alguns serviços especiais, como, por exemplo, o Instituto Nacional do Câncer ${ }^{175}$.

Pode-se depreender, portanto, que está em andamento um processo de ampla redefinição do papel e da inserção da epidemiologia e da vigilância epidemiológica no sistema de saúde. No entanto, embora tenha avançado nos últimos anos, este ainda não se desdobrou em muitas mudanças concretas na prática cotidiana deste sistema.

\section{Programas de Atenção Integral à Saúde}

Os programas de atenção integral à saúde no Brasil, tal como se apresentam hoje, têm como referências o lema "Saúde para todos no ano 2000" (SPT2000), assumido na 30ª Conferência Mundial de Saúde, em 1977, e desdobrado na 32ª Conferência, em 1979, e a estratégia de Atenção Primária à Saúde (APS), aprovada na Conferência de Alma-Ata, em 1978 175,205. Ambos representaram um marco na reorientação do enfoque dos problemas e sistemas de saúde $95,101,143$.

O lema SPT2000, "alcançar para todos os cidadãos do mundo no ano 2000 um grau de saúde que lhes permita levar uma vida social e economicamente ativa" (OMs, 
1977 apud OPS(OMs, 1980), foi proposto como meta social para os governos e a Organização Mundial da Saúde. Teve como eixo central elevar a qualidade de vida da população e a contribuição do setor saúde na diminuição das desigualdades sociais e eliminar a pobreza extrema.

Para tal, foram definidas prioridades em três áreas:

1. grupos humanos: populaçōes de extrema pobreza em áreas rurais e urbanas e, nelas, as crianças menores de cinco anos, mulheres e trabalhadores. Nos países cuja população já demonstrasse envelhecimento, deveriam também ser incluídos como prioritários os idosos;

2. nivel e estrutura de saúde: aumento da esperança de vida ao nascer, através da diminuição e mudança do padrão de mortalidade;

3. melhoramento dos níveis nacionais de bem-estar: aumento da disponibilidade e acessibilidade de toda população a serviços de saúde, educação, ambiente, alimentação, moradia e lazer, bem como melhoria dos niveis de renda e emprego ${ }^{155}$.

A Atenção Primária à Saúde, aprovada como estratégia fundamental para o alcance do lema SPT2000, foi definida como a

"(...) assistência sanitária essencial baseada em métodos e tecnologias práticos, cientificamente fundados e socialmente aceitáveis, posta ao alcance de todos os individuos e familias da comunidade mediante sua plena participação e a um custo que a comunidade e o país possam suportar, em todas e cada uma das etapas de seu desenvolvimento com um espirito de auto-responsabilidade e autodeterminação. A atenção primária forma parte integrante tanto do sistema nacional de saúde, do qual constitui a função central e o núcleo principal, como do desenvolvimento social e econômico global da comunidade. Representa o primeiro nivel de contato entre os indivíduos, a familia e a comunidade com o sistema nacional de saúde, levando o mais próximo possível a atenção de saúde ao lugar onde residem e trabalham as pessoas, e constitui o primeiro elemento de um processo permanente de assistência sanitária" (WHO/UNICEF, 1978).

Nesta estratégia foi proposto, ainda, que a prática de atenção primária seria adequada à cada realidade, devendo contemplar, pelo menos: a promoção de uma nutrição adequada, saneamento básico, atenção matemo-infantil - incluindo planejamento familiar, imunização contra as principais doenças transmissiveis, prevenção e controle de endemias, educação em saúde e tratamento apropriado dos agravos mais comuns ${ }^{205}$.

Como componentes básicos da APS, foram preconizadas a melhoria do meio ambiente e a extensão da cobertura dos serviços de saúde. Além disto, sugeriu-se que a operacionalização destes se desse através de programas práticos, com ênfase em atividades de promoção e prevenção devidamente combinadas com as de tratamento e reabilitação, estruturados de acordo com as necessidades dos grupos prioritários. Estes deveriam con- 
templar ações dirigidas à saúde materno-infantil, ao acompanhamento do desenvolvimento integral da criança, imunizações, enfermidades diarréicas, respiratórias agudas, de transmissão sexual, ocupacionais, cardiovasculares, degenerativas e câncer, e também dirigidas à saúde mental, malária e outras parasitoses, alimentação e nutrição, água potável e saneamento básico e saúde pública veterinária ${ }^{155,205}$.

Portanto, sem formalizar um esquema explicativo do processo de determinação do perfil nutricional, a estratégia de APS preconizou, para a rede de saúde, ações ligadas tanto à vertente de utilização biológica quanto à de consumo alimentar, seja investindo-se na quebra do circulo vicioso desnutrição-infecção ou na suplementação alimentar para crianças e gestantes. Esta última comporia um leque intersetorial de intervenções que combinariam estratégias para aumentar a disponibilidade de alimentos com outras especificas de correção da subnutrição.

A repercussão destas preconizações internacionais coincidiram, no Brasil, com o processo de redemocratização da sociedade, marcado, no campo da saúde, entre outros, pela valorização da necessidade de melhoria do atendimento à população; crise do modelo previdenciário vigente até o inicio dos anos 80; surgimento de propostas de reformas na prestação de serviços, buscando reverter o modelo que privilegiava os produtores privados de serviços de saúde e a ênfase à assistência médico-hospitalar; proposição de medidas que respondessem às necessidades da população; formulação de propostas racionalizadoras na prestação pública de serviços e investimento na ampliação de sua cobertura, através da criação de novas unidades de saúde $\mathbf{1}^{118,119,144,151}$.

Retomando o já mencionado no capitulo anterior, nos últimos anos tem acontecido um profundo reordenamento político e institucional do setor saúde, que tem como marco, no campo legislativo, a promulgação da Constituição Federal, em 1988, e a Lei Orgânica da Saúde, em 199027,29,153. Este reordenamento, sem dúvida, vem propiciando modificações na estrutura do sistema de saúde que, em linhas gerais, reforçam a politica de atenção primária à saúde.

Em relação aos programas de atenção integral, vale dizer que sua estruturação, no inicio dos anos 80, inspirou-se em alguns programas isolados de atenção primária experienciados até então, como será visto a seguir ${ }^{144}$.

$\dot{E}$ importante reforçar que não se pretende, aqui, avaliar os programas quanto à pertinência de seu conteúdo ou à sua real execução, mas, sim, buscar elementos que subsidiem a discussão, realizada no capítulo 4 , sobre a viabilidade de articulação entre eles, tal como estão preconizados, a vigilância epidemiológica e o SISVAN.

Em linhas gerais, estes programas assumem a assistência integral como pressuposto básico, implicando ações dirigidas ao atendimento global das necessidades prioritárias dos grupos-alvo, visando o impacto em sua morbimortalidade. Estas ações devem ser de ampla aplicação no sistema básico de assistência, alta eficácia na resolução de problemas especificos de saúde, baixos custos e complexidade tecnológica adequada para execução nos vários níveis dos serviços ${ }^{119}$.

A integralidade da assistência pressupõe, também, uma prática educativa que permeie todas as ações desenvolvidas, permitindo que a população se aproprie dos conhecimentos necessários para a manutenção e recuperação de sua saúde ${ }^{118,119}$. 


\section{Programa de Atenção Integral à Saúde da Criança (PAISC)}

Proposto pelo MS em 1984, o PAISC é dirigido a crianças menores de cinco anos e tem, como marca fundamental, o investimento no deslocamento de uma assistência baseada em patologias para um enfoque que contemple a criança em seu processo de crescimento e desenvolvimento ${ }^{118}$.

Seu principal objetivo é reduzir a morbimortalidade naquele grupo etário, procurando responder, de maneira racional e precoce, aos agravos mais freqüentes e de maior peso na mortalidade do mesmo, através de cinco ações básicas, quais sejam: acompanhamento do Crescimento e Desenvolvimento (CD), incentivo ao aleitamento materno e orientação alimentar para o desmame, imunização, controle das doenças diarréicas e controle das Infecções Respiratórias Agudas (IRA).

Acompanhamento do $C D$ : proposto como metodologia para organização da assistência à criança, deve atuar como atividade integradora das outras ações previstas no Programa, propiciando identificação oportuna daqueles doentes ou com risco de adoecerem, favorecendo intervenções precoces e possibilitando maior alocação de recursos assistenciais aos grupos mais vulneráveis ${ }^{118,130}$.

Tem como instrumento básico o Cartão da Criança, composto por dados de identificação, gráfico de crescimento (índice peso/idade, população de referência NCHS, pontos de corte: percentis 90 e 10), calendário vacinal e, depois de revisão normatizada em 92 , roteiro de acompanhamento do desenvolvimento ${ }^{128,130}$.

Reconhecendo-se o sinergismo desnutrição-infecção, recomenda-se a articulação da prática de acompanhamento do $\mathrm{CD}$ com os programas de suplementação alimentar existentes.

Incentivo ao Aleitamento Materno e Orientação Alimentar para o Desmame: tendo como objetivo principal a reversão da tendência de desmame precoce, ocorrida a partir dos anos 40, esta ação já vinha sendo desenvolvida há mais de três anos, através do Programa Nacional de Incentivo ao Aleitamento Materno, quando foi incorporada ao PAISC $^{18,131}$.

Reúne, no âmbito do sistema de saúde, práticas educativas quanto ao processo de lactação, suas vantagens e importância e quanto às técnicas de preparo da mama e de aleitamento; procedimentos capazes de tratar ou reduzir condições biológicas que poderão dificultar ou impedir o aleitamento; estruturação de alojamento conjunto nas maternidades; instruções para a introdução de outros alimentos no periodo do desmame e para a recuperação nutricional em nivel ambulatorial ${ }^{131}$.

Entre as ações que envolvem outros setores além da saúde estão as de rígido controle do marketing dos "sucedâneos" do leite materno e similares e as de cumprimento das leis que contemplam a mulher trabalhadora que está amamentando ${ }^{118,134}$.

Imunização: operacionalizada pelos serviços de VE, objetiva ampliar a cobertura vacinal entre os mais suscetiveis através de, entre outros, intensificação da aplicação das vacinas de rotina, valorização do cumprimento do calendário vacinal preconizado, captação precoce para vacinação, busca de faltosos para complementação de doses de vacinas e campanhas de imunização ${ }^{118}$. 
Controle das Doenças Diarréicas: iniciada em 1982 e integrada às demais atividades do PAISC em 1984, esta ação visa a diminuição dos agravos nutricionais e da mortalidade por desidratação. Para tal, envolve: normatização da definição de caso e uso de medicamentos em situações específicas; atividades de ampla utilização e difusão da terapia de reidratação oral; utilização da reidratação endovenosa em determinados casos; orientação alimentar durante o episódio diarréico, no sentido da manutenção do aleitamento materno e de dietas adequadas energeticamente; incentivo às outras ações do Programa descritas anteriormente; práticas educativas sobre saneamento e cuidados no manuseio de alimentos e controle das epidemias, estando, esta última ação, vinculada diretamente ao serviço de $V E^{117,118,132}$.

Controle das IRA: tem como objetivos centrais a queda da mortalidade, particularmente por pneumonia em menores de um ano, a redução de casos graves e complicações, bem como do uso inadequado de antibióticos e outros medicamentos. Abrange, fundamentalmente, a normatização da definição de caso, baseada em observação clínica (revisada em 1991), e da conduta especifica a ser adotada $118,121,133$.

\section{Programa de Atenção Integral à Saúde da Mulher (PAISM)}

Procurando minimizar as principais causas de morbimortalidade da população feminina, o PAISM tem como objetivos programáticos: o aumento da cobertura e da concentração de consultas do atendimento pré-natal; a melhoria da cobertura e da qualidade da assistência ao parto, com diminuição do indice de cesarianas desnecessárias; aumento dos indices de aleitamento materno; implantação ou ampliação de atividades de identificação e controle do câncer cérvico-uterino e de mama, das doenças transmitidas sexualmente e de outras patologias de maior prevalência no grupo; desenvolvimento de atividades de regulação da fertilidade humana, através da contracepção ou correção de situações de infertilidade, e prevenção da gravidez indesejada, evitando-se o aborto provocado ${ }^{143}$.

Estes objetivos são operacionalizados através de três grupos de atividades de assistência: clínico-ginecológica, pré-natal e ao parto e puerpério imediato.

Assistência clínico-ginecológica: tem como instrumento o Cartão da Mulher e engloba ações e procedimentos voltados para a identificação, diagnóstico e tratamento de patologias sistêmicas, do aparelho reprodutivo - incluindo prevenção do câncer de mama e de colo uterino, orientação sobre planejamento familiar e atendimento ao puerpério tardio.

A avaliação do estado nutricional é mencionada como um dos procedimentos incluidos nesta assistência. No entanto, não há preconização de indicadores e instrumentos que permitam operacionalizá-la.

Assistência pré-natal: dirigida para promoção da saúde e identificação precoce de șituações de risco para a gestante ou o concepto, reúne os seguintes procedimentos: anamnese e exame clinico inicial, acompanhamento periódico e sistemático, orientações tanto em relação ao processo de lactação e sua importância, quanto a futuras alternativas de contracepção.

Tem como instrumento o Cartão da Gestante, que contempla o indice peso para es- 
tatura para idade gestacional como indicador do estado nutricional, sendo operacionalizado através do gráfico de Rosso $(1985)^{173}$.

Assistência ao parto e ao puerpério imediato: engloba as seguintes ações: anamnese e exame clínico-obstétrico, buscando detectar fatores que possam trazer complicações ao parto ou puerpério; acompanhamento sistemático dos periodos de dilatação, expulsão e dequitadura, garantindo que estes processos aconteçam de forma natural, sempre que possivel; assistência ao recém-nascido; estímulo ao aleitamento materno, se possivel ainda na sala de parto; implementação do alojamento conjunto nas maternidades; melhoria da qualidade da assistência ao parto hospitalar - através da capacitação da equipe de saúde - e ao parto domiciliar - através da capacitação de parteiras, fornecimento de material de parto e estabelecimento de mecanismos de referência; assistência ao puerpério imediato, com supervisão continuada; orientações sobre alternativas de contracepção; incentivo à manutenção da amamentação, manuseio de técnicas de relactação e tratamento de doenças mamárias.

Aqui também é citada a avaliação nutricional como procedimento inerente a esta assistência, mas sem formalização de indicadores para tal.

\section{Programa de Saúde do Adolescente (PROSAD)}

Desde 1986, o MS já havia englobado em suas ações a assistência primária à saúde do adolescente, dentro do contexto de atenção integral à saúde da mulher e da criança ${ }^{74}$.

O PROSAD, tal como se apresenta hoje, foi oficializado em 1989, sendo dirigido a individuos entre 10 e 19 anos. Além de pautar-se no princípio da integralidade das ações de saúde, reforça a perspectiva multidisciplinar da operacionalização da mesmas, bem como a integração intersetorial e interinstitucional dos órgãos envolvidos nesta operacionalização' 122,127 .

É composto pelas seguintes áreas de atuação ou ações programáticas: acompanhamento do $C D$, sexualidade, saúde bucal, saúde mental, saúde reprodutiva, saúde do escolar adolescente e prevenção de acidentes.

Acompanhamento do CD: preconizado como eixo central do PROSAD, engloba a avaliação do crescimento estatural (indice estatura/idade, população de referência NCHS, percentis disponiveis em gráfico: 97, 90, 50,10 e 3). Abarca também a avaliação da maturação sexual, utilizando-se dos diagramas de Tanner $(1976)^{188}$, que levam em conta o tamanho dos testículos e do pênis e o grau de aparecimento de pêlos pubianos, para os meninos, e o desenvolvimento das mamas, o grau de aparecimento dos pêlos pubianos e a idade da menarca, para as meninas ${ }^{122}$.

Sexualidade: sabendo-se ser impossivel a normatização desta área de atuação, em vez da padronização de procedimentos, as diretrizes do Programa oferecem uma exposição sintética do assunto, considerando os niveis de atenção e os conteúdos pertinentes à adolescência. Estão contemplados nesta exposição conteúdos de anatomia, fisiologia, esquema corporal, identidade psicossexual e aspectos psicossociais e socioculturais da sexualidade $^{123}$. 
Saúde bucal: envolve ações que enfatizem aspectos preventivos da saúde bucal ${ }^{127}$.

Saúde mental: reúne abordagem ampla sobre o desenvolvimento psicológico do adolescente, orientações de condutas que estimulem seu desenvolvimento harmônico e ações que permitam diagnóstico e tratamento precoces de distúrbios emocionais, psicomotores, de conduta, psicossomáticos, entre outros ${ }^{123}$.

Saúde reprodutiva: abarca as ações contempladas no PAISM: assistência ao pré-natal, parto e puerpério, planejamento familiar, prevenção e tratamento de doenças sexualmente transmissíveis e de problemas ginecológicos, com abordagem peculiar para a faixa etária alvo, quando necessário ${ }^{124}$.

Saúde do escolar adolescente: sugere investimento em trabalho conjunto dos setores saúde e educação no sentido de melhor compreender a relação entre saúde do adolescente e processo de aprendizagem ${ }^{127}$.

Prevenção de acidentes: sugere programas de caráter multisetorial e interdisciplinar que envolvam, entre outros, ações de educação para saúde e capacitação dos próprios adolescentes, pais e professores na promoção da segurança ${ }^{127}$.

\section{Programa Nacional de Saúde do Idoso (PNSI)}

São duas as principais justificativas para a proposição do $\mathrm{PNSI}^{126}$ :

1. o rápido e acentuado processo de envelhecimento da população brasileira, com conseqüente aumento da ocorrência de doenças crônicas não-transmissiveis e

2. a participação desproporcional dos idosos (indivíduos com 60 anos ou mais) na demanda aos serviços de saúde: levantamentos esporádicos têm sugerido que estes ocupam três vezes mais leitos do que sua proporção na população.

Estes dois fatos têm conseqüências profundas no financiamento do setor saúde, podendo-se prever uma enorme sobrecarga do mesmo, caso nenhuma medida seja tomada.

Ainda em fase de estruturação, o PNSI não prevê ações programáticas propriamente ditas, mas linhas gerais de atuação. Tem como proposta básica a adequação da estrutura do sus às necessidades do idoso e a capacitação de profissionais de saúde para o atendimento especializado a este grupo alvo.

Estas linhas gerais de atuação podem ser resumidas em: promoção da saúde do idoso, procurando mantê-lo com autonomia em sua comunidade o maior tempo possível; desenvolvimento de pólos de excelência que realizem atendimento multidisciplinar e permitam capacitação de profissional; sensibilização e treinamento de profissionais para atenção especifica à saúde do idoso, permitindo um atendimento básico integrado a ações de prevenção e reabilitação de incapacidades; promoção da educação em saúde da população para as questões específicas dos idosos, buscando otimizar o suporte familiar e social a eles e realização de estudos epidemiológicos que subsidiem futuras ações de saúde. 


\section{Programas Voltados para a Saúde do Adulto}

As ações dirigidas aos adultos diferem das anteriormente descritas para os outros grupos populacionais, uma vez que não estão articuladas na forma de um programa de atenção integral. O comumente denominado "programa do adulto" é, na verdade, a execução dos programas de controle do diabetes mellitus e da hipertensão arterial. Normatizados pela Divisão Nacional de Doenças Crônico-Degenerativas da Secretaria Nacional de Programas Especiais de Saúde do Ministério da Saúde, são dirigidos ao controle específico de um agravo, funcionando de forma paralela.

\section{Programa de Controle do Diabetes Mellitus}

O objetivo principal deste programa é a redução da mortalidade por diabetes. Entre as justificativas apontadas para a proposição do mesmo figuram ${ }^{136}$ :

1. a magnitude deste agravo na população brasileira (estimada em 5,6\%), que vem crescendo à medida que a população envelhece e que se aprofunda a urbanização, com todos os seus desdobramentos - sedentarismo, mudança de hábitos alimentares, entre outros;

2. suas repercussões em termos de mortes prematuras, incapacidades e encurtamento do tempo médio de vida produtiva;

3. sua importante relação com a ocorrência de doenças cardiovasculares, principal causa de morte no pais, e

4. a grande desinformação, por parte dos pacientes, profissionais de saúde e população sobre a dimensão deste agravo em termos de morbimortalidade.

Partindo-se da premissa de que o melhor controle da doença reduz a incidência e a gravidade das complicações secundárias, são valorizadas e normatizadas as seguintes ações e temas:

1. diagnóstico - baseando-se em presença de sintomas e sinais clínicos e confirmação laboratorial (glicemia em jejum e teste oral de tolerância à glicose), são definidas duas classes clínicas deste agravo: Tipo I ou insulino-dependente e Tipo II ou não-insulino-dependente;

2. tratamento - através do manuseio da dieta, hipoglicemiantes orais, insulina, exercícios físicos e educação do paciente diabético;

3. incentivo à automonitorização da glicemia como melhor forma de controle do diabetes e

4. valorização do papel da rede básica de assistência à saúde, atrelada a um sistema de referência e contra-referência, no controle do agravo em questão. 
Vale ressaltar que a obesidade é apontada como fator não genético mais freqüentemente relacionado ao diabetes Tipo II, sendo o controle daquela uma das principais intervenções na prevenção e tratamento deste agravo. Como referência para o cálculo do 'peso ideal', são sugeridas, sem maiores justificativas desta escolha, as seguintes fórmulas:

- para homens: estatura (cm) - 100 - (estatura-100).20-1

- para mulheres: estatura (cm) - 100 - (estatura-100).10

É interessante observar que, embora a obesidade seja indicada como importante determinante do diabetes e seja fornecida uma forma de cálculo de 'peso ideal' em relação à estatura, não são normatizados pontos de corte que definam grupos sob risco nutricional.

\section{Programa Nacional de Educação e Controle da Hipertensão Arterial (PNECHA)}

O PNECHA foi proposto tendo como base as seguintes argumentações:

1. as doenças cardiovasculares são as principais causas de morte no país, já sendo responsáveis por $30,8 \%$ dos óbitos em todas as faixas etárias e $20 \%$ dos ocorridos na faixa entre 20 e 49 anos;

2. entre os fatores de risco mais relevantes para este grupo de agravos - alcoolismo, diabetes mellitus, hereditariedade, hipercolesterolemia, obesidade, tabagismo, estresse a Hipertensão Arterial (HA) é um dos mais importantes;

3. este agravo é hoje considerado um problema de saúde pública, com $39 \%$ dos casos ocorrendo na população entre 20 e 49 anos;

4. mais da metade dos casos não sabem que são hipertensos e

5. a HA e suas complicações figuram entre as causas mais freqüentes de auxilios-doença $e$ invalidez permanente concedidos ${ }^{137}$.

Como ações do programa são padronizados e recomendados:

1. critérios para o diagnóstico da HA, baseados nos valores de pressão arterial sistólica e diastólica e

2. tratamento dirigido à normalização da pressão arterial, com manuseio da dieta, abolição do tabagismo, abolição ou redução do consumo de bebidas alcoólicas, exercício físico aeróbico regular e medicamentos apropriados.

Também neste programa é valorizado o acompanhamento do peso corporal com vistas a controlar a obesidade, sendo sugeridas as seguintes fórmulas para o cálculo do peso de referência: 
- para homens de compleição: pequena: (estatura (cm) - 100) - 10\% média : (estatura $(\mathrm{cm})-100)-5 \%$ grande : (estatura $(\mathrm{cm})-100)$

- para mulheres de compleição: pequena: (estatura $(\mathrm{cm})-100)$ - 5\% média : (estatura $(\mathrm{cm})-100)-10 \%$ grande : (estatura (cm) - 100) - 15\%

Como faixas de estado nutricional são sugeridas:

- peso normal: até $5 \%$ do peso-referência;

- excesso de peso: peso 6 a 19\% superior ao de referência e

- obesidade: peso $20 \%$ ou mais superior ao de referência. 


\section{Capítulo 4}

\section{O SISVAN no setor saúde}

São inúmeras as possibilidades de recorte do tema central deste ensaio, qual seja o de cotejar a proposta de SISVAN com determinadas práticas implementadas na rede de saúde, buscando delinear possibilidades e limitações daquela em servir de instrumento para as respostas que esta possa dar aos agravos nutricionais da população brasileira.

Optou-se pela utilização da revisão bibliográfica realizada nos capitulos anteriores como, mais que subsidio, um roteiro para análise do tema. Portanto, esta será dividida em dois itens: o primeiro, tendo como base os capítulos 1 e 2, confrontará a proposta de sisVAN, tal como vem sendo implementada, com o papel da rede saúde em lidar com o perfil nutricional da população. O segundo, baseado no capitulo 3, tratará das possibilidades e limitações do SISVAN junto às práticas de vigilância epidemiológica e atenção integral, estas últimas norteadas pelos programas preconizados pelo Ministério da Saúde.

Para facilitar uma eventual reconsulta da revisão já apresentada, os trechos que abordarem conteúdos comentados em capítulos anteriores trarão indicada a página onde isto foi feito.

\section{O SISVAN na rede de saúde}

Antes de serem analisadas as possibilidades e limitações do SISVAN, na rede, como instrumento de resposta aos agravos nutricionais da população, faz-se necessário refletir sobre qual o papel atribuido ao setor saúde frente a estes agravos, isto é, que ações lhe cabem institucionalmente.

Em documento especifico sobre o tema, a oMs (1981) ${ }^{147}$ atribuiu a este setor as seguintes funções gerais na área de alimentação e nutrição:

1. cooperação do nivel federal no processo de planejamento e implementação de estratégias multisetoriais de alimentação e nutrição, através do diagnóstico e análise dos problemas nutricionais da população, operacionalização de programas e contribuição na estruturação de um 'sistema de vigilância de alimentos e nutrição;

2. realização de ações preventivas e curativas na rede de saúde, figurando, entre elas, o tratamento das doenças nutricionais (e.g. kwashiorkor e marasmo) e de infecções 
como diarréias e infecções respiratórias, imunização, planejamento familiar, incentivo ao aleitamento matemo, atividades educativas destinadas a melhorar as práticas dietéticas e suplementação alimentar e/ou de nutrientes especificos;

3. participação na vigilância e avaliação de planos e programas nutricionais.

Ainda neste documento, foram explicitados dois pressupostos que embasaram a proposição destas funções. $O$ primeiro diz respeito ao reconhecimento da determinação múltipla do perfil nutricional (p. 25) e à adoção do planejamento multisetorial em nutrição (p. 18) como marco teórico promissor para a definição das atribuições do setor saúde nesta área. Como ressalva, levantou-se o risco de os problemas nutricionais serem vistos como "preocupação de todo mundo e responsabilidade de ninguém" (OMS, 1981, p. 10).

O segundo refere-se à estratégia de atenção primária (p. 68) como norteadora das ações previstas, ressaltando-se a área de nutrição como sendo de responsabilidade do setor saúde e a subnutrição infantil como principal problema a ser enfrentado. Além disto, foi valorizada a importância de as intervenções propostas serem subsidiadas pelo conhecimento da magnitude dos problemas nutricionais e seus determinantes. Lançando-se mão do modelo causal do perfil nutricional (p. 26), foi reforçada a atuação primordial daquele setor junto aos determinantes da utilização biológica - particularmente os mais imediatos, como as infecções - e a atuação complementar junto aos de consumo dos alimentos.

Além destas colocações, vale a pena serem retomadas as premissas apresentadas no capítulo 1 (p. 15), quais sejam:

1. o estado nutricional é um elemento do processo saúde-doença,

2. o setor saúde tem o papel de responder resolutivamente aos agravos da população baseando-se no perfil de morbimortalidade da mesma e

3. esta resolutividade frente aos agravos nutricionais só será possível se forem viabilizadas ações que respondam a eles de maneira integrada aos outros agravos que compõem o perfil de morbimortalidade da população.

Sob estas perspectivas, justifica-se um sistema de informações que diagnostique a situação nutricional da população e avalie o impacto das ações propostas. No entanto, o fato de ser cabivel um sistema de informações não significa que ele deva ter os moldes do SISVAN.

Chega-se, então, ao tema central deste capitulo: a análise sobre as possibilidades e limitações do sISVAN, como vem sendo proposto e implementado, em cumprir o que é esperado dele. Para tal, será retomada a revisão, feita no capitulo 1 , sobre seu histórico.

A proposição do sisvan teve como pano de fundo, entre outros fatores, crises internacionais de caráter econômico e de produção de alimentos e o empobrecimento das populações mais vulneráveis dos paises não-desenvolvidos (p. 18). Além disto, ainda estava por vir a reformulação do papel do setor saúde frente aos agravos nutricionais, deslanchada pela proposição do lema "Saúde Para Todos no Ano 2000" (SPT2000) e da estratégia de Atenção Primária à Saúde (APS) (p. 68). 
Provavelmente estes foram alguns dos motivos pelos quais o modelo explicativo do processo de determinação do estado nutricional então adotado tenha contemplado, quase que exclusivamente, a vertente de consumo alimentar, sendo secundarizada a de utilização biológica dos alimentos e a de cuidado infantil (p. 26). Ademais, uma vez que a subnutrição infantil era apontada como o aspecto nutricional mais relevante nos paises não-desenvolvidos, o SISVAN foi dirigido à vigilância deste agravo, incorporando, em algumas experiências, o binômio mãe-filho ${ }^{63,102,147}$.

O marco teórico do planejamento multisetorial, presente à época (p. 18), operacionalizou-se na formulação de um sIsvaN com perspectivas intersetoriais (p. 19). Neste, previa-se a participação do setor saúde fundamentalmente na produção de dados sobre estado nutricional, dando subsídios para a avaliação do impacto das ações viabilizadas pelos diferentes setores ${ }^{102}$.

Como desdobramento do modelo explicativo adotado, que enfatiza o consumo de alimentos como vertente principal de determinação do estado nutricional, a ação específica de nutrição comumente esperada para o setor saúde tem sido, historicamente, a viabilização de programas de distribuição de alimentos, estando o SISVAN vinculado à triagem de beneficiários para estes.

Reforçando este enfoque, na argumentação que fundamenta a proposta de segurança alimentar, a distribuição de alimentos, comumente prevista para o setor saúde, é apontada como uma das ações responsáveis pela diminuição da insegurança no acesso aos alimentos, um dos componentes fundamentais da mesma. O SISVAN, por sua vez, é visto como uma forma de otimizar estes programas de distribuição de gêneros ${ }^{157}$.

É verdade que o lema SPT2000 e a estratégia de APS, propostos em fins dos anos 70 (p. 68), serviram não só para legitimar as ações de nutrição já desenvolvidas no setor saúde, mas também para delinear melhor o papel deste, ressaltando o impacto de medidas gerais de saúde no perfil nutricional ${ }^{147,155}$. Sob este enfoque, então, tanto as ações previstas quanto o SISVAN poderiam estar, na rede de saúde, articulados não só às duas vertentes de determinação do estado nutricional mais tradicionalmente documentadas: a de consumo e a de utilização biológica de alimentos (p. 26), como também à terceira: cuidado infantil (p. 28). Em inúmeros paises, entre eles o Brasil, no entanto, o que prevaleceu como principal resposta do setor saúde à questão nutricional, até recentemente, foi a suplementação alimentar.

Os principais pilares desta resposta têm sido, então, o planejamento multisetorial como marco teórico para a formulação de ações; a compreensão da subnutriçāo infantil como sendo o principal (na prática, exclusivo) agravo nutricional a ser enfrentado por este setor e a valorização da vertente de consumo alimentar no norteamento das ações do mesmo no campo da alimentação e nutrição. Os comentários traçados a seguir sobre cada um destes pilares baseiam-se, fundamentalmente, na realidade brasileira, podendo, em linhas gerais, ser extrapolados para outros paises com características semelhantes. 


\section{Sobre o marco teórico do planejamento multisetorial}

O marco teórico do planejamento multisetorial em nutrição apresentou, sob a perspectiva do desenvolvimento econômico, a meta de erradicação da subnutrição (p. 18). Apostou na produção de dados de saúde e nutrição com o intuito de sensibilizar e instrumentalizar os níveis políticos decisórios, acreditando que, com estas informações, seria possivel avaliar as medidas de desenvolvimento adotadas. No entanto, aquelas só apontaram problemas inerentes à própria condição de subdesenvolvimento dos países, cujas soluções - comumente amplas, como melhores condições de vida, redução do analfabetismo, geração de empregos, entre outras - estão previstas nos planos de desenvolvimento dos paises, havendo ou não sISVAN ${ }^{158}$. Além disto, por serem acompanhados indicadores de resultado do processo de determinação do estado nutricional, que não apresenta relações simples e diretas com medidas no campo da economia e alimentação, o sistema implementado não tem servido às necessidades dos planejadores (p. 24).

Têm sido apontadas limitações importantes na viabilização de um sISvAN que tenha como pano de fundo este marco teórico, afirmando-se, por exemplo, que

"(...) o modelo da planificação nutricional é teoricamente elegante mas operacionalmente ambicioso; politicamente é ingênuo" (ORALC/FAO, sd, p. 1);

Ou, ainda, que

"(...) o empenho em conseguir a participação multisetorial, conceitualmente indispensável, pode ser entrave para o SISVAN. Às vezes, por conflitos de interesses, alguns setores envolvidos se sentem desmotivados a participar, somando-se o fato de inexistirem modelos realistas de coordenação" (Arruda, 1992, p. 97).

Como alternativas de referência teórica, são valorizadas a atenção primária, para o setor saúde, e a segurança alimentar, para este e outros setores como a agricultura e a economia. De qualquer forma, tem sido enfatizado o fortalecimento e a utilização do SISVAN intra-setorialmente:

"(...) as prioridades na apreciação do "problema nutricional" têm mudado ao longo do tempo. As carências de vitaminas representaram a preocupação principal até 1950; a insuficiência de proteinas, desde o início da década de 1950 até meados da década de 1970; e a planificação multisetorial em nutrição atẻ fins da mesma década. Em 1978, adotou-se em Alma-Ata o enfoque de atenção primária da saúde, que devolveu o papel de protagonista às comunidades, como estratégia para atingir a saúde para todos no ano 2.000 . Alguns dos programas nutricionais com melhores resultados foram implementados com este enfoque" (UNICEF, 1990, p. 11-12);

"(...) diante de quadro tão promissor (estruturação do Sistema Único de Saúde no Brasil), considero mais importante fortalecer a politica setorial 
do SISVAN do que despender esforços ingentes na coordenação de outros setores influentes na politica de alimentação e nutrição, que seguem cumprindo sua função" (Arruda, 1992, p. 100)

"(...) dentro do setor saúde, parece consensual o reconhecimento de que a vigilância alimentar e nutricional deve resgatar, ao máximo, o compromisso das ações básicas e integradas de saúde" (Batista Filho \& Rissin, 1993, p. 103)

"(...) surge como estratégia operativa que a construção de um SISVAN tem como primeira fase necessária a consolidação dos sistemas de informação existentes e o fortalecimento da capacidade de análise e interpretação em níveis chaves de decisão. A conformação de uma unidade central de análise e a integração das ações dispersas de informação-decisão em um sistema nacional é tarefa de uma fase posterior" (ORALC/FAO, sd, p. 10);

"(...) ao operacionalizar-se a interação entre informação e decisão, e ao integrar-se a relação entre técnicos e políticos, o esquema institucional se fortalece; de igual maneira, ao afirmar-se a segurança alimentar como objetivo nacional, o binômio. "vigilância central" - "decisão multisetorial" encontrará seu espaço natural dentro do aparato" (ORALC/FAO, sd, p. 10-11).

Partindo destas colocações, fica clara a necessidade de o setor saúde fazer do sISVAN um instrumento para uso próprio, qualificando as intervenções que lhe cabem, antes ou independentemente de pretender orientar ações de demais setores. Para tal, é importante que o SISVAN esteja estruturado de forma a subsidiar e avaliar ações especificas do setor saúde não só nos níveis central e regional, mas, especialmente, no nivel local de assistência, instância que mantém contato direto com a clientela.

Sob este enfoque, o estado nutricional deverá ser valorizado como um componente fundamental do processo saúde-doença e como fator de risco para enfermidades relevantes no atual perfil de morbimortalidade da população (p. 15). Ademais, a informação sobre a magnitude dos próprios agravos nutricionais e suas características de ocorrência devem servir como elemento norteador da reorganização dos serviços.

\section{Sobre a subnutrição infantil}

Sem dúvida, foi pertinente a escolha, tanto pelos propositores do SISVAN quanto da APS, da subnutrição infantil como agravo central a ser enfrentado pelos paises não desenvolvidos, devido à sua magnitude e influência nas principais causas de morte deste grupo na década de $70^{63,102,155,205}$.

No entanto, ao menos para a realidade brasileira, fatores como mudanças demográfícas (p. 46) e epidemiológicas (p. 46), intervenções implementadas, particularmente no setor saúde (p. 56), e ampliação das atribuições deste setor (p. 66) e da compreensão do seu papel no campo da alimentação e nutrição colocaram, para o mesmo, novos desafios. 
Entre estes, o de responder criativa e resolutivamente aos seguintes agravos: desnutrição infantil, principalmente crônica (p. 53), baixo peso ao nascer (p. 51), baixo peso e o sobrepeso em gestantes (p. 60) e excesso de peso em adultos e idosos (p. 57).

O fato de a desnutrição infantil ser eminentemente crônica, ou seja, fruto de espoliações repetidas e continuadas, reforça a pertinência do investimento em ações de promoção à saúde e prevenção e controle dos agravos mais comuns neste grupo. Além disto, aponta para a necessidade de se aprofundar o conhecimento sobre as complexas interações do binômio desnutrição-infecção no atual perfil de morbimortalidade infantil.

A queda do Coeficiente de Mortalidade Infantil (CMI), fundamentalmente pela diminuição do seu componente tardio (p. 48), realça a necessidade de se manterem e ampliarem as ações a este dirigidas. Por outro lado, o importante peso das causas perinatais no CMI, bem como a incidência ainda alta de baixo peso ao nascer, explicitam a urgência de se ampliar a cobertura e melhorar a qualidade do atendimento ao pré-natal, parto e puerpério.

Quanto ao estado nutricional de gestantes, merece ser ampliado o enfoque tradicional, que se concentra no controle do ganho insuficiente de peso com vistas à prevenção do baixo peso ao nascer. Complementando-se esta dimensão, indiscutivelmente importante, deve ser ressaltado o acompanhamento da saúde da própria mulher, valorizando-se os controles de baixo peso e sobrepeso ${ }^{57}$. Este último influencia a saúde materna durante e depois da gravidez (obesidade), aumenta o risco de complicações no parto e do baixo peso ao nascer, uma vez que pode contribuir para a ocorrência de partos prematuros, devido a intercorrências como diabetes e hipertensão.

A obesidade tem seu acompanhamento previsto nos programas de controle do diabetes (p. 75) e da hipertensão (p. 75). No entanto, sua magnitude (p. 58) e relevância como fator de risco para as doenças cardio-vasculares, principal causa de morte no pais (p. 48; 75), justificam uma melhor estruturação do seu acompanhamento na rede de saúde. Ademais, por ser também prevalente em populações de baixa renda, coloca, para pesquisadores e profissionais de saúde, o desafio de rever a concepção tradicional de que a obesidade seria sempre expressão da opulência ${ }^{147}$, implicando o redimensionamento das condutas adotadas.

Vale ressaltar que as mudanças no perfil nutricional da população brasileira entre 1974 e 1989 - redução da desnutrição em menores de cinco anos, também em números absolutos (p. 53), maior relevância da desnutrição crônica neste grupo (p. 53), redução do baixo peso e aumento do sobrepeso e obesidade em adultos (p. 59) - acompanham o relatado sobre a transição epidemiológica e a atual complexidade do perfil de morbimortalidade da população brasileira. Com isto, reforça-se a pertinência de serem pensadas ações que respondam de maneira integrada a estes perfis, aspecto levantado nas premissas deste ensaio (p. 15).

À luz dos comentários anteriores, então, justifica-se a urgência em se superar a concepção de que a subnutrição infantil seria o principal agravo nutricional a ser enfrentado pela rede de saúde. Não se trata de secundarizá-la, mas de, respondendo à complexidade do perfil epidemiológico da população, ampliar o leque de agravos a serem acompanhados pelo setor saúde, de acordo com peculiaridades regionais e locais. 
Portanto, para que o SISVAN cumpra seu papel de subsidiar e avaliar ações que respondam a este perfil epidemiológico, faz-se necessária a ampliação também do leque de indicadores sobre os quais este sistema fornece informações.

\section{Sobre a vertente de consumo alimentar}

Dada a inserção do setor saúde no processo de determinação do estado nutricional, a valorização exclusiva da vertente alimentar circunscreve a atuação deste a duas possibilidades de práticas: (a) as educativas, dirigidas fundamentalmente ao incentivo ao aleitamento materno, orientação alimentar para o desmame e orientações dietéticas para a clientela em geral, e (b) as de suplementação alimentar ou medicamentosa, esta última no caso de nutrientes específicos, como o ferro e a vitamina $A^{16}$.

Sobre estas duas possibilidades de atuação, é muito corrente se ouvir, na rede de saúde, que de pouco ou nada adiantam orientações alimentares se o problema da desnutrição (como único agravo relevante) é social, ou, mais diretamente, falta de comida ${ }^{57}$. Portanto, se a rede não puder lançar mão de programas de suplementação alimentar, não terá como agir.

Este enfoque, baseado numa compreensão simplista do processo de determinação do estado nutricional (fome = desnutrição), comumente imobiliza os profissionais de saúde e secundariza não só as práticas educativas mas também outras, ligadas à vertente de utilização biológica dos alimentos, comentadas mais à frente, que são de responsabilidade intransferivel do setor saúde.

Ao mesmo tempo em que se reconhece que a desnutrição tem uma dimensão social muito mais ampla que as possibilidades e caracteristicas de atuação do setor saúde ${ }^{147}$, a ele é atribuida a mediação desta dimensão, através da prática de suplementação alimentar. Embasa esta atribuição a compreensão de que cabem a este setor a diminuição das desigualdades sociais $^{155}$ bem como a colaboração com programas multisetoriais, como visto anteriormente.

Parece que é este o enquadramento que faz a suplementação alimentar estar prevista dentro da estratégia de APS (p. 69), ser proposta por documentos e conferências internacionais ${ }^{147,194}$, aparecer como um dos componentes das açōes específicas da Saúde para o controle das deficiências nutricionais ${ }^{16}$ e estar preconizada como um dos eixos da politica de combate à fome do atual governo brasileiro (p. 37).

No entanto, as opiniōes sobre a prática de suplementação alimentar, particularmente via rede de saúde, não são consensuais. Por sua complexidade, este tema merece um aprofundamento que extrapola as dimensões deste livro.

Apenas a titulo de ilustração, retomando e complementando alguns aspectos da análise destes programas já comentados anteriormente (p. 33), podem ser apontados como aspectos polêmicos os seguintes $96,160,162,163,165$ :

1. a escolha da suplementação alimentar como resposta governamental à questão nutricional em detrimento de outras intervenções, menos onerosas e com maior possibilidade de cobertura, como o subsídio a determinados alimentos e a execução de programas alternativos de comercialização de gêneros; 
2. o alto custo dos programas em contraposição à sua baixa cobertura e seu impacto questionável;

3. a utilização destes programas em práticas clientelistas e de manipulação política;

4. os problemas inerentes à sua operacionalização, no que diz respeito à compra, estocagem e distribuição, $\mathrm{e}$

5. a escolha do alimento a ser distribuido: se in natura ou formulado; se dirigido à toda a familia ou a um determinado indivíduo ou subgrupo da mesma.

Em relação ao setor saúde especificamente, podem ser citados também:

1. a definição dos critérios de admissão no programa: se geográficos (determinada área), sociais (renda familiar) e/ou orgânicos (indices antropométricos inferiores ao esperado);

2. a discussão sobre se é ou não papel da rede de saúde distribuir alimentos;

3. a vinculação dos programas às ações básicas de saúde, que, se por um lado, pode aumentar a freqüência e $o$ vínculo com os serviços de saúde, por outro pode distorcer o papel destes, deslocando a compreensão da população para aquelas ações como mediadoras da distribuição de alimentos, $e$

4. a proposição de que os beneficiários sejam triados entre a clientela da rede de saúde, embora se saiba que esta ainda tem baixa cobertura dos grupos alvo, não conseguindo captar muitos dos beneficiários potenciais.

De qualquer forma, independentemente deste debate, importa para esta discussão a constatação de que a suplementação alimentar para crianças menores de cinco anos e, às vezes, gestantes, é tradicionalmente apontada como possibilidade exclusiva ou, pelo menos, central, de resposta da rede de saúde frente à questão nutricional. Como desdobramento, o papel do SISVAN se restringiria à seleção e acompanhamento de beneficiários de programas de distribuição de gêneros. Por este raciocinio, se não estiver prevista esta distribuição na rede, não haverá possibilidades de intervenção.

As afirmações feitas no parágrafo anterior podem parecer exageradas, uma vez que vêm sendo implementadas, nos últimos anos, açōes de atenção primária que têm impacto no perfil nutricional da população (p. 70), bem como vem sendo recomendada a articulação entre programas de suplementação alimentar e ações básicas de saúde (p. 22, 38). No entanto, não parece estar presente, na conduta dos profissionais de saúde em geral, o reconhecimento de que estas açōes, por si só, jả sejam uma resposta do setor saúde frente à questão nutricional ${ }^{57,147}$.

Para a reversão deste quadro, é fundamental que o setor saúde tome para si as ações que são de sua responsabilidade intransferivel, dando conta de aspectos vinculados às vertentes de utilização biológica, consumo dos alimentos e cuidado infantil ${ }^{10,16,194}$. O sIsVAN, por sua vez, deve ser estruturado de forma a contemplar indicadores que contribuam para este processo. 


\section{O SISVAN, a vigilância epidemiológica e a atenção integral à saúde}

\section{O SISVAN e a vigilância epidemiológica}

Embora a Vigilância Epidemiológica (VE) tenha servido de referência para a formulação da Vigilância Nutricional (VN) (p. 18), só muito recentemente tem-se incentivado, no Brasil, algum nível de vínculo institucional e operacional entre elas ${ }^{10,129}$. Pode-se mesmo afirmar que, antes de fins da década de 80 , no Brasil, as dimensões previstas para a VE (p. 66), a não-legitimidade do SISVAN em nivel nacional (p. 32, 34) e a estrutura do sistema de saúde então vigente (p. 69) não ofereciam condições minimas para algum nivel de articulação entre estes dois sistemas de vigilância. Concretamente, até então, a implementação de ambas na rede de saúde vinha sendo paralela, apresentando, entretanto, uma semelhança: a falta de consenso sobre a etapa de "intervenção" fazer parte ou não de suas atribuições (p. 64) $)^{84,102,147}$.

$\mathrm{Na}$ verdade, estes dois sistemas apresentaram, historicamente, objetos de controle e estruturas de funcionamento bastante diferentes. A VE, inspirada nas práticas de quarentena e campanhas de controle de agravos especificos, esteve voltada, tradicionalmente, para doenças transmissiveis (p. 65). Entre suas características de funcionamento figuram uma definição de "caso" o mais precisa possivel, a fim de que se garantam medidas de controle (busca ativa, investigaçōes, tratamento profilático dos contatos) e um tratamento especifico para o mesmo, comumente viável através do manuseio de drogas pelo próprio setor saúde. Seu fluxo de informações tem como fonte básica a notificação de casos incidentes.

A VN, por sua vez, tem como objeto de controle agravos não-transmissiveis, que não possuem um agente etiológico específico passivel de medicalização, sendo causados por fatores múltiplos (p. 25). Fora formas clinicas como marasmo e kwashiorkor, a definição de "caso" no campo dos agravos nutricionais é bastante complexa, sendo reconhecida a dificuldade em se determinar "o ponto em que uma adaptação biológica deve ser considerada patológica" (OMS, 1981, p. 7). O controle e o tratamento envolvem medidas diversas, tradicionalmente atribuidas a setores externos à Saúde ou a programas especificos nela desenvolvidos, como a suplementação alimentar. Seu fluxo de informações tem como fonte básica a notificação de casos prevalentes.

Nos últimos anos, entretanto, ampliaram-se as atribuições da VE (p. 67). Esta passou a incorporar, entre outros, o acompanhamento do perfil global de saúde, de agravos não-transmissiveis e de determinantes do processo saúde-doença, devendo, então, integrar-se às demais atividades da rede de saúde e, para tal, rever suas metodologias em relação a indicadores, fluxo de dados e intervenções.

Esta ampliação acena para um quadro promissor de articulação entre VE e VN. Na verdade, pode-se vislumbrar esta última não mais como um sistema de informações à parte, mas como um elemento da dimensão ampliada da primeira, podendo ter participação em várias das suas atribuições. Indicadores como peso ao nascer e crescimento de crianças podem fornecer informações importantes sobre o perfil global de saúde da população. Vários indicadores de estado nutricional podem oferecer um panorama importante sobre 
fatores de risco de causas de adoecimento e morte relevantes no atual perfil epidemiológico da população (p. 48). Agravos nutricionais propriamente ditos podem (e devem) compor o leque de agravos não transmissiveis a serem acompanhados pela VE. Para que esta integração se dê de forma tecnicamente consistente, a revisão de indicadores, fluxo de dados e intervenções também deve perpassar a VN.

O investimento na implantação do Sistema de Informação sobre Nascidos Vivos (SINASC) (p. 67), parece ser um passo viável e fundamental para a ampliação da VE e sua integração com a VN. A viabilização deste sistema representa um avanço para a rede sob vários aspectos. Além de potencializar a qualificação da atenção à mulher e à criança, significa uma ampliação concreta das perspectivas da atividade de vigilância epidemiológica, não só pela natureza dos eventos a serem acompanhados, particularmente o baixo peso ao nascer, mas também pela possibilidade de interface com os programas de atenção integral.

Portanto, a incorporação do acompanhamento do perfil nutricional da população pela VE, a começar pelo baixo peso ao nascer, parece ser um filão estratégico e promissor para a integração daquela com as outras ações da rede.

Para que esta articulação entre VN e VE ocorra, entretanto, como citado acima, é necessário rever, nos dois sistemas, fluxo de dados, indicadores e intervenção, esta última aprofundada, em relação ao SISVAN, no tópico a seguir. Quanto aos dois primeiros, cabem, ainda neste item, alguns comentários, com o intuito de se levantarem aspectos preliminares para este debate. Os exemplos usados a seguir deter-se-ão a crianças menores de cinco anos por ser o grupo etário em que o sISVAN está mais difundido no Brasil.

Em relação aos indicadores, já foi mencionada a necessidade da ampliação do leque daqueles sobre os quais cabe ao sISVAN fornecer informações. Além disto, devem ser garantidas, simultaneamente (a) a comparabilidade das informações geradas nas diversas regiōes geográficas, o que implica padronização nacional de índices, pontos de corte e populações de referência e (b) a manutenção do Valor Preditivo Positivo (VPP) dos indicadores escolhidos em realidades com diferentes prevalências do evento sob vigilância, 0 que implica incluir pontos de corte complementares, que apresentem diferentes especificidades (capacidade de um teste de conferir diagnóstico negativo a quem de fato não apresenta um determinado agravo ${ }^{79}$. O VPP de um teste é a probabilidade de uma pessoa de fato apresentar um determinado agravo dado que seu teste deu positivo ${ }^{79}$. No caso, seria a probabilidade de uma criança de fato estar com seu estado nutricional comprometido, uma vez que esteja abaixo de um determinado ponto de corte.

Por exemplo: para o indice massa corporal/idade, preconizado no Programa de Atenção Integral à Saúde da Criança (p. 70), seriam utilizados dois pontos de corte: os percentis 10 e 3 (P10 e P3, respectivamente) da curva do NCHS ${ }^{141}$. A inclusão do P3 como ponto de corte complementar para baixo peso em menores de cinco anos facilitaria a triagem dos que apresentam maior risco ${ }^{36}$, além de acrescentar, a um instrumento já existente (o Cartão da Criança), uma curva que se aproxima da de -2 desvios-padrão, recomendada pela OMS como limite para o déficit nutricional (p. 49) ${ }^{206}$. Ademais, naquelas realidades onde a prevalência de crianças abaixo do $\mathrm{P} 10$ não é alta, esta inclusão permitiria o aumento do VPP.

A título de ilustração, observe-se o caso do municipio do Rio de Janeiro (dados da 
rede básica de saúde municipal, primeiro semestre de 1994): enquanto a prevalência de crianças abaixo de P10, na faixa etária de maior risco (entre 6 e 24 meses), fica próxima a $18 \%$ ( 1,8 vezes o esperado, que seria $10 \%$ ), a de crianças entre $\mathrm{P} 10$ e P3 fica em tomo de $11 \%$ (1,57 vezes o esperado, que seria $7 \%$ ) e a daquelas abaixo de P3 fica próxima a $9 \%$ ( 3 vezes o esperado, que seria 3\%). Portanto, de cada 3 crianças entre P10 e P3, duas recebem diagnóstico de risco nutricional sem o apresentarem ('falsos positivos'), dos quais apenas uma apresenta risco de fato ('verdadeiro positivo'). Em relação àquelas abaixo de P3, a situação se inverte: de cada 3 crianças, duas são 'verdadeiro positivo'.

Quanto ao fluxo de dados, um aspecto que merece revisão é a periodicidade de coleta e consolidação. Tradicionalmente, os dados são coletados cotidianamente na rotina dos serviços, sendo consolidados mensalmente. Em algumas experiências, só são consideradas as primeiras consultas do mês, em outras, todas as consultas, havendo ou não diferenciação da primeira para as subseqüentes ${ }^{57}$. Em contraste a esta forma de produzir informações, vem sendo proposto, internacionalmente, o uso de pesquisa por amostragem e sistemas sentinela, particularmente para análise em nivel central ${ }^{194}$. Cabe regsitrar que um dos primeiros movimentos neste sentido, aqui no Brasil, vem ocorrendo na rede estadual de saúde de São Paulo, que está em processo de reestruturação de seu fluxo.

Para se aprofundar a discussão sobre periodicidade de coleta e consolidação, faz-se necessário levar em conta, além de questões que dizem respeito à factibilidade de operacionalização, dois aspectos centrais. $O$ primeiro diz respeito à natureza do evento ou agravo sob vigilância que, no caso de crianças menores de cinco anos, é a desnutrição. Tratase, portanto, como abordado anteriormente, de um agravo não-transmissivel, com comportamento diferente daqueles acompanhados tradicionalmente pela vigilância epidemiológica. De que maneira esta diferença está contemplada na estrutura do fluxo de dados, particularmente na coleta e consolidação? Isto é, a natureza do evento demanda (ou mesmo justifica) uma coleta diária com vistas a uma consolidação mensal?

O segundo refere-se à utilidade da coleta e consolidação 'tradicionais' (a partir de dados diários ou mensais) para um dos objetivos centrais do sISVAN, que é o de produzir informações para uma análise agregada de tendências do evento sob vigilância. De fato, as alterações das freqüências de desnutrição infantil nas unidades de saúde parecem ter menos a ver com mudanças reais de incidência e prevalência e mais com oscilações de oferta de serviços (e.g. (a) maior adesão, levando a consultas freqüentes; (b) oferta seletiva, com triagem dos de maior risco).

Diante destes argumentos preliminares, a proposta de pesquisa por amostragem parece ser, a princípio, interessante, até porque, por ser periódica (por exemplo, semestral), permitiria aprofundar o diagnóstico sobre quem são as crianças de fato em risco. Isto não significa que o acompanhamento do estado nutricional em nivel ambulatorial, bem como seu registro cotidiano, devam ser abandonados ou realizados só periodicamente em amostras. Eles se justificam por si mesmos e devem ser mantidos dentro da perspectiva de qualificação do atendimento prestado. $O$ que deve ser modificada é a compreensão sobre $a$ interface da dimensão individual (acompanhamento ambulatorial) com a coletiva (análise agregada de tendências).

Fato é que este debate está ainda muito incipiente em nosso meio, tanto acadêmico 
como na rede de saúde, devendo ser incentivado e fortalecido, contemplando, inclusive, as diferenças regionais, em termos de magnitude e peculiaridades do processo de determinação do agravo sob vigilância. Não é demais reforçar que quaisquer mudanças de fluxo devem ser amplamente discutidas, de forma a garantir que sejam amadurecidas entre os agentes envolvidos no SISVAN.

\section{O SISVAN e os programas de atenção integral}

Tem sido corrente a alusão ao papel do SISVAN no resgate e racionalização das ações básicas de saúde, particularmente no nivel local de assistência ${ }^{10,17,194}$. Não são muitas, no entanto, as publicações em que se aprofunda a forma como isto se daria ${ }^{57}$. Na verdade, parece que $o$ que mobiliza as diversas instâncias da rede de saúde para o resgate e racionalização mencionados acima não é exatamente o fluxo de dados em si, com suas informações produzidas rotineiramente, mas sim a proposta de se repensar a prática de assistência à luz de um componente (o nutricional) do perfil epidemiológico da população, valorizando-se o monitoramento do estado nutricional como procedimento relevante para a qualificação da assistência. Ou seja, o responsável por aquele resgate e racionalização seria mais o "movimento pró-SISVAN" do que o sistema de informações em si.

Buscando-se aprofundar a reflexão sobre o papel do sisvaN na atenção integral, parece ser um bom começo a afirmação de que o SISVAN conferiria uma dimensão coletiva aos programas, sendo ilustrativa a metáfora entre estes e o olhar para uma árvore. 0 atendimento clínico representaria um olhar minucioso para cada folha, atentando para seus contornos, textura, vitalidade, entre outros, sem, no entanto, conseguir vislumbrar as dimensões da árvore da qual aquelas fariam parte. O sISVAN, ao contrário, representaria o olhar para a árvore que, embora perdesse o detalhamento das folhas, conseguiria vislumbrar a silhueta destas juntas, podendo distinguir áreas daquela que necessitariam de maior cuidado. Este sistema, então, teria como papel fundamental subsidiar a reorganização dos serviços, sendo o perfil nutricional da população um dos critérios para a mesma.

Embora aquele possa ser um bom começo, não é suficiente. De pouco adianta, por exemplo, os consolidados do SISVAN apontarem qual a proporção de gestantes sob risco nutricional e o serviço reorganizar-se de forma a garantir o vínculo daquelas a ele, se, na conduta do profissional que as atende, não estiver presente uma atenção diferenciada para este componente do seu estado de saúde. $O$ que se quer dizer é que, sendo a abordagem individual o carro-chefe das práticas de atenção implementadas no nível local de assistência, a dimensão coletiva só tem sentido quando, integrando-se à primeira, contribuir para qualificá-la. Mais que isto, de pouco adianta o investimento na implantação do sisvaN se não forem propostas, simultaneamente, formas de intervenção que respondam resolutivamente ao perfil nutricional diagnosticado por aquele sistema e que sejam passiveis de operacionalização na rede de saúde.

Portanto, para que as informações produzidas de fato instrumentalizem a prática dos serviços, reforça-se a necessidade - comentada no item anterior - de revisão dos indicadores e pontos de corte escolhidos, bem como os contomos do fluxo de dados do sis- 
VAN. Complementarmente, um passo fundamental para a articulação entre este sistema $e$ as ações de saúde é a incorporação do acompanhamento do estado nutricional de toda clientela à prática clínica, como forma de qualificá-la. Para tal, faz-se necessário não só normatizar este acompanhamento, mas também sensibilizar e capacitar os profissionais para implementá-lo no dia-a-dia.

Quanto à normatização deste procedimento junto aos programas de atenção integral já implementados, observam-se situações bastante distintas. No Programa de Atenção Integral à Saúde da Criança, este acompanhamento é tido como eixo das demais ações contempladas, servindo o Cartão da Criança como instrumento para tal (p. 70). Além disto, embora não signifiquem que este esteja implantado satisfatoriamente na rede, dois aspectos facilitam a incorporação do mesmo à prática clínica do grupo alvo deste programa: o fato de o binômio infecção-desnutrição ser amplamente reconhecido como central no seu perfil de morbimortalidade, e o acompanhamento do crescimento ser legitimado como uma prática inerente à assistência infantil.

Já no Programa de Atenção Integral à Saúde da Mulher, embora o acompanhamento do estado nutricional da gestante e o instrumento para tal estejam preconizados (p. 72), sua implementação é ainda bastante incipiente. Portanto, valorizar este acompanhamento como qualificação do pré-natal é condição básica para se pensar o SISVAN neste programa.

Quanto ao Programa de Saúde do Adolescente, embora assim preconizado (p. 72), o acompanhamento do crescimento e desenvolvimento não conseguiu ser, ainda, o carrochefe das demais ações previstas. Dois motivos parecem explicar este fato: a pressão que outros aspectos deste grupo alvo exercem sobre a organização dos serviços (sexualidade, uso de drogas, fracasso escolar, gravidez indesejada, entre outros), e a ausência de normatização pelo Ministério da Saúde, até fins de 1993, de indices, população padrão e instrumentos para aquele acompanhamento ${ }^{122}$.

Em relação ao Programa Nacional de Saúde do Idoso, ainda bastante embrionário, não há nenhum tipo de indicação explícita para o acompanhamento em questão (p. 73). Para adultos em geral, por outro lado, há menção de controle da obesidade entre os incluidos nos programas de controle do diabetes (p. 75) e da hipertensão arterial (p. 75). Ou seja, só depois de o cliente ser diagnosticado como apresentando características que o incluem em um dos dois programas, o estado nutricional passa, em tese, a ser acompanhado.

Sob a perspectiva da atenção primária à saúde, no entanto, seria esperado que o acompanhamento nutricional deste grupo fosse anterior àqueles diagnósticos, expressando o papel da nutrição nas doenças do aparelho circulatório, principal causa de morte no pais $^{106}$. Isto permitiria a detecção, ainda mais precoce, de individuos sob risco de desenvolver diabetes, hipertensão e seus complicadores, além de outros fatores que oferecem risco para a ocorrência de doenças cardiovasculares, como, por exemplo, dieta desbalanceada e hipercolesterolemia ${ }^{135}$.

Na verdade, o acompanhamento do estado nutricional como prática rotineira deveria fazer parte de uma reordenação da assistência prevista para os adultos, ainda compartimentalizada e direcionada para problemas especificos ${ }^{39}$. Assim como o acompanhamento do crescimento e desenvolvimento deve articular as ações dirigidas aos menores de cinco anos, o acompanhamento do estado nutricional de adultos poderia cumprir o papel de in- 
tegrar as ações voltadas para este grupo. Uma experiência piloto de implantação de um Cartão do Adulto vem sendo organizada por profissionais do Centro de Saúde Escola Germano Sinval Faria, unidade vinculada à Escola Nacional de Saúde Pública da Fundação Oswaldo Cruz, Rio de Janeiro. Neste cartão, entre outras informações, consta um gráfico de acompanhamento do estado nutricional através do Indice de Massa Corporal ${ }^{2}$.

À luz da discussão realizada neste capitulo, quanto às respostas da rede pública de assistência à saúde frente ao perfil nutricional da população, além de se mostrar necessária a experimentação de novas e criativas intervenções, devem ser reforçados e amplia$\operatorname{dos}^{16,17,57,194}$ :

1. o atendimento diferenciado aos individuos sob risco, garantindo-se agendamento específico e ações de prevenção e tratamento precoce de infecções (principalmente para o grupo infantil) e de agravos ligados às doenças cardiovasculares (principalmente para os adultos);

2. as práticas educativas ligadas ao consumo alimentar: incentivo ao aleitamento materno, orientação efetiva para o periodo do desmame, orientações alimentares dirigidas a agravos carenciais bem como à prevenção e controle da obesidade, hipertensão e doenças cardiovasculares, $e$

3. outras ações de promoção à saúde, como o pré-natal, atendimento ao parto e puerpério, contracepção, que contribuem direta ou indiretamente para o estado nutricional da mulher e da criança.

Quanto ao SISvAN, ficou evidenciada e fundamentada a necessidade de sua reestruturação, esperando-se que seja gradual, acompanhando a consolidação do sus. Para que esta de fato ocorra, então, deve-se ter como pano de fundo não só os argumentos apresentados neste capitulo, mas também a experiência concreta de implantação deste sistema na rede pública de assistência à saúde, o paralelismo histórico entre este, as ações de saúde e as politicas de alimentação e nutrição no Brasil (p. 38), sua situação ainda bastante incipiente (p. 39) e, ainda, o atual momento de profunda reformulação do sistema de saúde e de ampla discussão sobre a questão alimentar e nutricional no pais (p. 38). Caso todos estes aspectos não sejam levados em conta, corre-se o risco de a reestruturação mencionada acima restringir-se ao âmbito técnico, não tendo o respaldo político necessário para ser implementada.

\section{Considerações finais}

A reflexão realizada neste ensaio procurou delinear alguns aspectos que contribuíssem para a compreensão do porquê do distanciamento entre as práticas desenvolvidas na rede pública de assistência à saúde e a proposta de SISVAN, tal como vem sendo preconizada e implantada. O desenvolvimento do tema explicitou que, para aquele sistema se tornar de fato orgânico à rede e cumprir o papel de subsidiar respostas efetivas aos agravos nutricionais da população, é necessário que assuma um contorno integrado às práticas 
nela desenvolvidas, e, ao mesmo tempo, contribua para a reformulação das mesmas. Para tal, deve ser reestruturado de forma a:

1. qualificar as intervenções específicas daquele setor, particularmente no nivel local de assistência, contemplando indicadores que contribuam para a estruturação das mesmas;

2. ampliar o leque de indicadores sobre os quais fornece informações, com vistas a abarcar o complexo perfil nutricional da população brasileira;

3. contribuir para a articulação entre vigilância epidemiológica e os programas de atenção integral à saúde e

4. influenciar não só a reorganização dos serviços mas também o redimensionamento da prática de atendimento individual, contribuindo para a legitimação do acompanhamento do estado nutricional da clientela atendida como qualificador da assistência prestada.

Para que todos estes aspectos da reestruturação do SISVAN sejam melhor fundamentados, uma série de temas e experiências merecem ser aprofundados e amadurecidos, tanto em relação às práticas da rede, no campo da alimentação e nutrição, quanto sob a perspectiva do SISVAN como sistema de informações. Faz-se necessário, para tal, um empreendimento conjunto de instituições acadêmicas e órgãos e unidades do Sistema Único de Saúde, no sentido de, por exemplo:

1. experimentar, na rede de saúde, novos modelos de intervenção nutricional para os diversos grupos sob risco, contemplando ações educativas e de atenção diferenciada, adaptadas às realidades dos diferentes estados e municipios;

2. revisitar e aprofundar os modelos explicativos dos determinantes do atual perfil nutricional da população, detalhando a especificidade de cada um dos agravos mais relevantes em cada região do pais e, diante disto, concentrar esforços nos fatores passíveis de intervenção no setor saúde. Em alguns contextos, as ações que trariam maior impacto não seriam obrigatoriamente da área de nutrição, mas influenciariam a frequêencia dos agravos nutricionais. Um exemplo seriam as açōes voltadas para a redução do baixo peso ao nascer: em regiōes menos empobrecidas - como as áreas metropolitanas da região Sudeste -, a educação sexual de adolescentes, a garantia de acesso a contraceptivos, campanhas antifumo e o controle precoce de intercorrências durante a gravidez talvez tivessem mais impacto na incidência do evento em questão do que o monitoramento do ganho de peso gestacional e a suplementação alimentar durante a gravidez $^{113}$;

3. revisar e preconizar orientações alimentares básicas, principalmente para o periodo do desmame, pré-natal e para adultos, passíveis de difusão por qualquer profissional de saúde $^{185}$;

4. investir em estudos sobre como se expressa o binômio infecção-desnutrição infantil numa população onde prevalece a desnutrição crônica. Isto é, quantificar e qualificar, se possivel, o risco de adoecer que esta forma de desnutrição possa apresentar. Um 
primeiro passo talvez seja refinar os dados de morbidade produzidos na rotina dos serviços de atenção primária, de forma a possibilitar análises mais aprofundadas. Este refinamento poderia se dar, por exemplo, através da utilização de grupos de agravos menos abrangentes do que os apresentados no Classificação Internacional de Problemas em Atenção Primária- (CIPSAP, 1986) ${ }^{41}$ uma vez que estes parecem não conseguir apontar muitas diferenças entre grupos em diferentes situações nutricionais ${ }^{36}$;

5. ampliar para outros municipios a experiência do sistema de vigilância de nascidos de baixo peso, já existente em alguns ${ }^{183}$, tendo como subsidio as informações produzidas pelo Sistema de Informação sobre Nascidos Vivos (SINASC);

6. viabilizar diagnósticos nutricionais de grupos outros que não da clientela atendida na rotina dos serviços de atenção primária. Como exemplo, avaliação da estatura em escolares, já realizada em alguns paises, ampliando os grupos-alvo e indicadores sob vigilância 106,158; avaliação de crianças menores de cinco anos que compareçam às campanhas de vacinação, como uma forma a mais de captação de grupos sob risco, mediando a baixa cobertura dos serviços de saúde ${ }^{54}$; avaliação de adultos funcionários de uma determinada instituição (como, por exemplo, no exame anual periódico) $^{177}$, como etapa inicial de um elenco de atividades dirigidas à prevenção de doenças cardiovasculares;

7. experimentar estratégias de implantação do sISVAN que dêem conta de sua inserção na prática da rede de saúde ${ }^{47,55,57,176}$. Estas devem envolver sensibilização e capacitação dos profissionais de todos os niveis, tendo como pano de fundo a preocupação de, além da viabilização de um fluxo de dados confiável, contribuir para a mudança da postura dos profissionais frente à questão nutricional, influenciando sua conduta na prática de atenção à saúde;

8. redimensionar o fluxo de dados do sISvan de forma a contemplar o perfil epidemiológico e as caracteristicas dos agravos nutricionais dos diversos grupos-alvo;

9. revisar os indicadores de estado nutricional preconizados para o SISVAN, tanto em relação à sua validade (capacidade de expressar o evento que se quer acompanhar) quanto em relação à pertinência da escolha de seus pontos de corte, para fins de intervenção na rede (sensibilidade, especificidade, valor preditivo). Quando necessário, investir em estudos de construção e/ou validação de novos indices e/ou pontos de corte;

10. testar modelos de avaliação formal do SISVAN. Como qualquer sistema de vigilância, deve ser submetido a critérios que avaliem (a) a importância dos eventos sob vigilância, através de elementos como, por exemplo, prevalência, severidade e capacidade de serem prevenidos; (b) objetivos e componentes do fluxo de dados; (c) a utilidade do sistema (se alcança seus objetivos e se isto leva a resultados positivos no perfil de saúde da população) (d) seus custos (diretos e indiretos); (e) sua qualidade, determinada, fundamentalmente, por características como: simplicidade, flexibilidade, aceitabilidade, sensibilidade, valores preditivos positivo e negativo, representatividade e oportunidade $50,57,94$. 
$O$ investimento nestes temas e experiências poderá propiciar uma ampliação da compreensão do papel da rede de saúde frente aos agravos nutricionais da população. Poderá, também, fornecer subsidios para que o sISVAN contribua, de forma mais plena, para a maior efetividade das ações implementadas neste campo. 


\section{Referências Bibliográficas}

1. ABRASCO. Plano diretor para o desenvolvimento da epidemiologia no Brasil. Rio de Janeiro, Associação Brasileira de Pós-Graduaçāo em Saúde Coletiva, 1989. 40 pp.

2. ANJOS, L. A. Indice de massa corporal (massa corporal.estatura ${ }^{-2}$ ) como indicador do estado nutricional de adultos: uma revisão da literatura. Revista de Saúde Pública, Sāo Paulo, 26(6): 431-6, 1992.

3. ANJOS, L. A. Valores antropométricos da população adulta brasileira: resultados da Pesquisa Nacional sobre Saúde e Nutrição. Tese apresentada ao Departamento de Nutrição Social da Universidade Federal Fluminense para concorrer à vaga de professor titular em Nutrição e Saúde Püblica, Rio de Janeiro, 1993. 53pp.

4. ANJOS, L. A.; SILVA, D. O.; SERRĀO, S. A. \& SILVA, C. V. C. Vigilância Nutricional em adultos: experiência de uma unidade de saúde atendendo população favelada. Cadernos de Saúde Pública, Rio de Janeiro, 8(1): 50-6, 1992.

5. ARANDA-PASTOR, J.; KEVANY, J. P. Estabelecimiento de sistemas de vigilancia alimentaria e nutricional y contribuicion del sector salud. Boletin de la Oficina Sanitaria Panamericana, 89(6):473-8, 1980.

6. ARAÚJO, J. D. Polarização epidemiológica no Brasil. Informe Epidemiológico do SUS, Brasilia, Ano I, 2: 5-16, julho, 1992.

7. ARIAS, C. V. El programa de nutrición de Costa Rica. In: OPAS. Vigilancia alimentaria y nutricional en las Americas. Washington, Organización Panamericana de la Salud/Organización Mundial de la Salud, 1989. pp. 133-6.

8. ARIZA MACÍAS, A.; DAZA, C. H.; PRADILLA, A. Fundamentos de un sistema de vigilancia alimentaria e nutricional. Boletin de la Oficina Sanitaria Panamericana, 89(6): 538-45, 1980.

9. ARNAULD, J.; IMMINK, M. \& ALARCÓN, J. Seguridad alimentaria y vigilancia alimentaria e nutricional - un enfoque funcional. In: OPAS. Vigilancia alimentaria y nutricional en las Americas. Washington, Organización Panamericana de la Salud/ Organización Mundial de la Salud, 1989. pp. 93-8.

10. ARRUDA, B. K. G. Sistema de Vigilância Alimentar e Nutricional. Frustraçōes, desafios e perspectivas. Cadernos de Saúde Pública, Rio de Janeiro, 8(1):96-101, 1992. 
11. ARRUDA, I. K. G. O Sisvan e as alternativas de intervenção. Boletim Nacional Sisvan, Brasilia, 1: 15-7, 1991.

12. BARBOSA, N. O Sisvan no Brasil. Boletim Nacional Sisvan, Brasilia, 1: 2, 1991.

13. BATISTA Filho, M. Saúde e nutrição. In: ROUQUAYROL, M. Z. Epidemiologia e saúde. $2^{\text {I }}$ ed. Rio de Janeiro, Mesdi, 1986. pp. 343-61.

14. BATISTA Filho, M. Sistema de vigilância nutricional - Brasil. Documento apresentado no Encontro sobre sistemas de Vigilância Alimentar e Nutricional na América Latina e Caribe. Santiago, Chile: 1985 . 40 pp. (mimeo).

15. BATISTA Filho, M. BLEIL, S. I. \& EYSDEN, L. M. V. Prevenção da desnutrição energético-proteica. Cadernos de Saúde Pública, Rio de Janeiro, 5(3): 276-83, 1989.

16. BATISTA Filho, M. \& RISSIN, A. Deficiências nutricionais: ações especificas do setor saúde para o seu controle. Cadernos de Saúde Pública, Rio de Janeiro, 9(2): 130-5, 1993.

17. BATISTA Filho, M. \& RISSIN, A. Vigilância alimentar e nutricional: antecedentes, objetivos e modalidades. A VAN no Brasil. Cadernos de Saúde Pública, Rio de Janeiro, 9(supl. 1): 99$105,1993$.

18. BATISTA Filho, M. \& SHIRAIWA, T. Indicadores de saúde para um sistema de vigilância nutricional. Cadernos de Saúde Pública, Rio de Janeiro, 5(1): 105-16, 1989.

19. BÉHAR, M. Análisis critico de los programas de nutrición aplicada en América Latina. Revista de Nutrição da PUCCAMP, Campinas, 4(1/2): 9-24, 1991.

20. BÉHAR, M. La nutrición, un problema social. Boletin de la Oficina Sanitaria Panamericana, 80(6): 533-9, 1976.

21. BEGHIN, I. Abordagem causal em nutriçào. In: GOUVEIA, E. L. C. (Org.) Nutrição, saúde \& comunidade. Rio de Janeiro, Revinter, 1990. pp. 181-93.

22. BEGHIN, I. Mejorando la nutrición a nivel local. Boletin de la Oficina Sanitaria Panamericana, 84(2): 108-17, 1978.

23. BEGHIN, I. Nutrition and national development planning. Bibliotheca Nutritio et Dieta, Switzerland, 28: 137-47, 1979.

24. BEGHIN, I.; CAP, M.; DUJARDIN, B. Guía para evaluar el estado de nutrición. Washington. Organizacion Panamericana de la Salud/Organización Mundial de la Salud, publicación cientifica n. $515,1989.86 \mathrm{pp}$.

25. BERKELMAN, R. L. \& BUEHLER, J. Public health surveillance of non-infectious chronic diseases: the potential to detect rapid changes in disease burden. International Journal of Epidemiology, 19(3): 628-35, 1990.

26. BOSI, M. L. M. A face oculta da nutrição: ciência e ideologia. Rio de Janeiro, Espaço e Tempo/Ed. UFRJ, 1988. 220 pp.

27. BRASIL. Constituição da República Federativa do Brasil. Brasilia, Centro Gráfico do Senado Federal, 1988.

28. BRASIL. Decreto no 807. Seçāo II. Ano XXXIV, n.76, Diário Oficial da República Federativa do Brasil. Brasilia, segunda-feira, 26 de abril de 1993. 
29. BRASIL. Lei Orgánica do SUS - n 8.080. Ministério da Saúde, Assessoria de Comunicação Social, Brasilia, 19 de setembro de 1990.

30. BRASIL. Portaria $n^{\circ}$ 080-P, 16 de outubro de 1990.

31. BRASIL. Portaria no 1156, Ministério da Saúde, Brasilia: 31 de agosto de 1990. Diário Oficial $\mathrm{n}^{0} 172,4$ de setembro de 1990.

32. BRASIL. Projeto de Resoluçāo n 84, de 1991 (CPI da Fome). Suplemento ao DCN - Seção I, n.64, Brasilia, Diário Oficial do Congresso Nacional, segunda-feira, 11 de maio de 1992.

33. CASTIEL, L. D. Considerações acerca da utilização da epidemiologia na avaliaçāo dos sistemas de saúde. Cadernos de Saúde Pública, Rio de Janeiro, 2(2): 184-90, 1986.

34. CASTIEL, L. D. Inefetividade e ineficiência: reflexões sobre a epidemiologia e os serviços de saúde de um Estado de mal-estar social. Cadernos de Saúde Pública, Rio de Janeiro, 6(1): 18-26, 1990.

35. CASTRO, A. B. \& SOUZA, F. E. P. A economia brasileira em marcha forçada. Rio de Janeiro, Paz e Terra, 1985. 217pp.

36. CASTRO, I. R. R. \& ANJOS, L. A. Vigilância nutricional e morbidade de crianças menores de 5 anos numa unidade básica de saúde: análise da série histórica 1987-91. Cadernos de Saúde Pública, Rio de Janeiro, 9(supl. 1): 36-45, 1993.

37. CENEPI. Editorial. Informe Epidemiológico do SUS. Brasilia, Ano I, 2, julho de 1992.

38. CENEPI. Editorial. Informe Epidemiológico do SUS. Brasilia, Ano II, 2, março/abril de 1993.

39. CENEPI. Editorial. Informe Epidemiológico do SUS. Brasilia, Ano II, 4, julho/agosto de 1993.

40. CHAHAD, J. P. Z \& MACEDO, R. Ajuste econômico e impacto social no Brasil: 1980-1987. Os efeitos sobre a população infantil. In: CHAHAD, J. P. Z. \& CERVINI, R. (Org.). Crise e infáncia no Brasil - o impacto das políticas de ajustamento económico. São Paulo, Instituto de Pesquisas Econômicas da Universidade de São Paulo, 1988. pp: 47-84.

41. CIPSAP. Classificación internacional de problemas en atención primária. Buenos Aires, Centro Internacional para la Medicina Familiar, 1986.

42. COHEN, B. E. Food security and hunger policy for the 1990s. Nutrition Today, 25(4): 23-7, 1990.

43. COITINHO, D. C. \& LEÃO, M. M. Evaluación del estado nutricional de adultos con base en el indice de masa corporal en Brasil. Brasilia, 1991. 65pp.

44. COITINHO, D. C.; LEĀO, M. M.; RECINE, E. \& SICHIERI, R. Condições nutricionais da população brasileira: adultos e idosos - Pesquisa Nacional sobre Saúde e Nutrição. Brasilia: 1991. 56pp.

45. COMISSÃO ESPECIAL PARA PROPOR MEDIDAS DE COMBATE À FOME, AO DESEMPREGO E À RECESSÃO. Plano de combate à fome e à miséria-princípios, prioridades e mapa das ações de governo. Brasilia, abril de 1993.

46. COMITÉ RIO. Açâo da cidadania contra a fome, a miséria e pela vida. Rio de Janeiro, sd. 
47. COSTA, S. F. S. (Coord.). Proposta preliminar de implantação do sistema de vigilancia nutricional (Sisvan) no estado da Bahia para 1991 e 1992 . Salvador, Secretaria de Estado de Saúde da Bahia, 1991. (mimeo).

48. CROVETTO, M. \& GARCIA, G. Una propuesta de indicadores de seguridad alimentaria. Revista Chilena de Nutricion, 18(1): 7-10, 1990.

49. De ONÍS, M.; MONTEIRO, C. A.; AKRÉ, J.; CLUGSTON, G. The worldwide magnitude of protein-energy malnutrition: an overview form the WHO global database on child growth. Bulletin of the World Health Organization, 7l(6): 703-12, 1993.

50. DECLICH, S. \& CARTER, A. O. Public health surveillance: historical origins, methods and evaluation. Bulletin of the World Health Organization, 72(2): 285-304, 1994.

51. DELGADO, G. C. Parceria governo-sociedade no combate à fome: avaliação e sugestões Parte I - versão preliminar. Texto apresentado no Seminário "Pobreza, fome e desnutrição no Brasil", organizado pelo Grupo de Trabalho Segurança Alimentar do Instituto de Estudos Avançados da Unversidade de São Paulo, São Paulo, 1994 (mimeo.).

52. DEVER, G. E. A. A epidemiologia na administração dos serviços de saúde. São Paulo, Pioneira, 1988. 394 pp.

53. DRĖZE, M J. \& SEN, A. Hunger and public action. Oxford, Clerandon Press, 1989.

54. ENSP/CSEGSF. Boletim Vigilância Nutricional . Rio de Janeiro, 5, Escola Nacional de Saúde Pública/ Centro de Saúde Escola Germano Sinval Faria, 1989.

55. ENSP/CSEGSF/SMS-RJ. Boletim Sisvan Rio. Rio de Janeiro, 12-14, Escola Nacional de Saúde Pública/Centro de Saúde Escola Germano Sinval Faria/Secretaria Municipal de Saúde do Rio de Janeiro, 1991-1993.

56. ENSP/CSEGSF/SMS-RJ. Boletim Sisvan Rio. Rio de Janeiro, 15, Escola Nacional de Saúde Pública/Centro de Saúde Escola Germano Sinval Faria/Secretaria Municipal de Saúde do Rio de Janeiro, 1994. (no prelo).

57. ENSP/PARES. O Sistema de Vigilancia Alimentar e Nutricional na rede de saude-manual para implantação. Rio de Janeiro, Escola Nacional de Saúde Pública/ Programa de Apoio à Reforma Sanitária, 1993. $76 \mathrm{pp}$.

58. EYLENBOSCH, W. J. \& NOAH, N. D. Surveillance in health and disease. New York, Oxford University Press, 1988.

59. FAO. Estado Actual y Perspectivas de la Vigilancia Alimentaria y Nutricional en America Latina y el Caribe. Oficina Regional de la FAO para America Latina y el Caribe (RLAC/94/14NUT-58), Santiago, Chile, 1994. 305pp.

60. FAO. Food systems and food security. In: Potentials for agricultural and rural development in Latin America and the Caribbean. Rome, 1988.

61. FAO/OMS. Conferencia Mundial de los Alimentos. Organización de las Naciones Unidas para la Agricultura y la Alimentación, Roma, 1974.

62. FAO/OMS. Conferencia Internacional sobre Nutrición. Roma, Food and Agriculture Organization/ Organización Mundial de la Salud, 1992. 
63. FAO/UNICEF/WHO Expert Committee. Methodology of nutritional surveillance. Geneva, World Health Organization, technical report series 593, 1976. $66 \mathrm{pp}$.

64. FNS/IMIP. Peso de gestantes. Fundação Nacional de Saúde/Instituto Materno-Infantil de Pernambuco. Boletim Sisvan, Recife, 10: 6, janeiro-abril, 1992.

65. FNS/IMIP. Sisvan internacional. Fundação Nacional de Saúde/Instituto Materno-Infantil de Pernambuco. Boletim Sisvan, Recife, 8: 16, maio-agosto, 1991.

66. FOSSAERT, H.; LLOPIS, A. \& TIGRE, C. H. Sistemas de Vigilancia Epidemiologica. Boletin de la Oficina Sanitaria Panamericana, 76(6): 512-28, 1974.

67. FRENK, J.; BOBADILLA, J. L.; STERN, C.; SEPÚlVEDA, J. \& CERVANTES, M. L. Health transition in middle-income countries: new challenges for health care. Health Policy and Planning, Oxford, 4(1): 29-39, 1989.

68. FRENK, J.; FREJKA, T.; BOBADILLA, J. L.; STERN, C.; LOZANO, R.; SEPÚLVEDA, J. \& JOSÉ, M. La transición epidemiologica en America Latina. Boletín de la Oficina Sanitaria Panamericana, $111(6):$ 485-96, 1991.

69. GARCÍA, C. \& CROVETTO, M. Situación de la seguridad alimentaria en America Latina. Revista Chilena de Nutrición, 19(1): 17-24, 1991.

70. GERJ/SES. Guia de vigilância epidemiológica. vol. 1. Governo do Estado do Rio de Janeiro/Secretaria de Estado de Saúde, Rio de Janeiro, Coordenadoria de Processamento de Dados/Centro de Informações de Saúde, 1991. 87 pp.

71. GHASSEMI, H. Supplementary feeding in programmes in developing countries: lessons of the eighties - Part I: findings of the report. Asia Pacific Journal of Clinical Nutrition, 1: 131$52,1992$.

72. GHASSEMI, H. Supplementary feeding in programmes in developing countries: lessons of the eighties - Part II: discussion and references. Asia Pacific Journal of Clinical Nutrition, 1 : 195-206, 1992.

73. GIBSON, R. S. Principles of Nutritional Assessment. New York, Oxford University Press, 1990. $691 \mathrm{pp}$.

74. GOMES, S. M. T. A. Características de um serviço de atenção primária. In: SOUZA, R. P. \& MAAKAROUM, M. F. (Coord.). Manual de adolescência. Sociedade Brasileira de Pediatria/ Comitê de Adolescência, 1989. pp 43-8.

75. GÒMEZ, F. et al. Mortalitiy in second and third degree malnutrition. Journal of Tropical Pediatrics, 2: 77-83, 1956.

76. GOVERNO PARALELO. O Brasil pode matar a fome - política nacional de Segurança Alimentar. Cartilhas Populares, 2, Gráfica FG, 1993.

77. GRUPO MULTIDISCIPLINARIO. "Vigilancia alimentaria e nutricional en Mexico". In: OPAS. Vigilancia Alimentaria y Nutricional en las Americas. Washington, Organización Panamericana de la Salud/Organización Mundial de la Salud, 1989. pp. 169-73.

78. GUIMARÃES, R. (Coord.) Novas perspectivas temáticas para a Epidemiologia. In: ABRASCO. Anais do $I^{\circ}$ Congresso Brasileiro de Epidemiologia: Epidemiologia e desigualdade social: os desafios do final do século. Rio de Janeiro, Associação Brasileira de Pós-Graduação em Saúde Coletiva, 1990. pp: 24 1-73. 
79. HENNEKENS, C. H. \& BURING, J. E. Epidemiology in Medicine. $1^{\text {st }}$ edition, Boston, Little, Brown and Company, 1987. 383 pp.

80. HORWITZ, A. El costo de la malnutrición. In: OPAS. Vigilancia alimentaria e nutricional en las Americas. Washington, Organización Panamericana de la Salud/ Organización Mundial de la Salud, 1989. pp. 19-54.

81. IBASE/ISER/FASE/IDAC. Primeira \& Última, $1-10,1993$.

82. IBRAHIM, M. A. Epidemiology and Health Policy. Maryland, Aspen Systems Corporation, 1985. 198pp.

83. INAN. Pesquisa Nacional sobre Saúde e Nutrição - perfil de crescimento da população brasileira de 0 a 25 anos. Brasilia, Instituto Nacional de Alimentação e Nutrição, 1990. 60pp.

84. INAN. Seminário sobre a operacionalização do Sistema de Vigilancia Alimentar e Nutricional - Sisvan: Documento Final. Brasilia, Instituto Nacional de Alimentação e Nutrição, 1990. $15 \mathrm{pp}$.

85. INAN. Sistema de Vigilancia Alimentar e Nutricional: proposta para atuação a nivel nacional. Brasilia, Instituto Nacional de Alimentação e Nutrição, sd. 6 pp.

86. INAN/FIBGE/IPEA. Pesquisa Nacional sobre Saúde e Nutrição - resultados preliminares. Brasilia, Instituto Nacional de Alimentação e Nutrição/Fundação Instituto Brasileiro de Geografia e Estatistica/Instituto de Planejamento Econômico e Social, 1990. 35pp.

87. IPLANCE/SES-CE/SSF-PMF/UNICEF. A situação nutricional em Fortaleza. Fundação Instituto de Planejamento do Ceará/Secretaria de Saúde do Estado do Ceará/ Secretaria de Saúde de Fortaleza/Fundo das Nações Unidas para a Infância. Boletim de Vigilancia Nutricional, Fortaleza, 3(1): 1-3, 1992.

88. IPLANCE/SES-CE/SSF-PMF/UNICEF. A situação nutricional em Fortaleza. Fundação Instituto de Planejamento do Ceará/Secretaria de Saúde do Estado do Ceará/ Secretaria de Saúde de Fortaleza/Fundo das Naçōes Unidas para a Infância. Boletim de Vigilancia Nutricional, Fortaleza, 4(1): 1-3, 1993.

89. IUNES, R. F. \& MONTEIRO, C. A. Razões para a melhoria do estado nutricional das crianças brasileiras nas décadas de 70 e 80. São Paulo, UNICEF/ NUPENS-USP, 1993.

90. JELLIFFE, D. B. \& JELLIFFE, E. F. P. Community nutritional assessment with special reference to less developed countries. New York, Oxford University Press, 1989.

91. JORNAL DO BRASIL. Itamar aceita plano de Lula contra a fome. Jornal do Brasil (Caderno Cidade), p. 18, 3 de fevereiro de 1993.

92. JORNAL O GLOBO. Itamar quer dólares para combater a fome. Jornal O Globo (Caderno O Pais), p. 7, 18 de fevereiro de 1993.

93. KELLY, A. 12. Nutritional surveillance in Europe: an operacional approach. In: BOSCH, W. J. E. \& NOAH, N. D. (editors) Surveillance in health and disease. New York, Oxford University Press, 1988. pp. 125-42.

94. KLAUCKE, D. N.; BUEHLER, J. W.; THACKER, S. B.; PARRISH, R. G.; TROWBRIDGE, F. L.; BERKELMAN, R. I. \& SURVEILLANCE COORDINATION GROUP. Guidelines for evaluating surveillance systems. Morbity and Mortality Weekly Report, 37, (S-5), May 6, 1988. $18 \mathrm{pp}$. 
95. KLECZKOWSKI, B. M.; ELLING, R. H. \& SMITH, D. L. Health system support for primary health care. World Health Organization, public health papers 80, 1984. $104 \mathrm{pp}$.

96. L'ABBATE, S. As políticas de alimentação e nutrição no Brasil - I. Periodo de 1940 a 1964. Revista de Nutrição PUCCAMP, 1(2): 87-138, 1988.

97. L'ABBATE, S. As politicas de alimentação e nutrição no Brasil - II. A partir dos anos setentas. Revista de Nutrição PUCCAMP, 2(1): 7-54, 1989.

98. LAURENTI, R. Transição demográfica e transição epidemiológica. In: ABRASCO. Anais do $1^{2}$ Congresso Brasileiro de Epidemiologia: Epidemiologia e desigualdade social: os desafios do final do século. Rio de Janeiro, Associação Brasileira de Pós-Graduação em Saúde Coletiva, 1990. pp.143-65.

99. LECHTIG, A. \& ARROYAVE, G. El problema nutricional en America Latina: definición, causas y lineas de acción para aliviario. Boletin de la Oficina Sanitaria Panamericana, 86(6): 478-92, 1979.

100. LILIENFELD, A. M. \& LILIENFELD, D. E. Fundamentos de epidemiologia. Mexico, Addison Wesley Iberoamericana, versión en español de la $2^{ \pm}$edición., 1986. 341 pp.

101. MAHLER, H. Promotion of primary health care in member countries of WHO. Public Health Reports, 93(2): 107-13, 1978.

102. MASON, J. B.; HABICHT, J.; TABATABAI, H.; VALVERDE, V. Vigilancia nutricional. Genebra, Organización Mundial de la Salud, 1984. 219 pp.

103. MAYER, J.; DWYER, J.; DOWD, K.; MAYER, L. (Editors) Food and nutrition policy in a changing world. New York, Oxford University Press, 1979.

104. MELLO JORGE, M. H. P.; GOTLIEB, S. L. D.; SOBOLL, M. L. M. S.; ALMEIDA, M. F. \& LATORRA, M. R. D. O. Sistema de Informação sobre Nascidos Vivos (SINASC). Informe Epidemiológico do SUS, Brasilia: Ano I, 4: 5-16, setembro, 1992.

105. MINAYO, M. C. S. (Org.) Raizes da Fome. 2' ediçăo. Petrópolis, Vozes/Fase, 1986. 185 Pp.

106. MOCK, N. B. \& BERTRAND, W. E. Marco conceptual para los sistemas de vigilancia nutricional. Boletín de la Oficina Sanitaria Panamericana, 115(6): 511-22, 1993.

107. MONTEIRO, C. A. A dimensão da pobreza, da fome e da desnutrição no Brasil. Texto apresentado no seminário "Pobreza, fome e desnutrição no Brasil", organizado pelo Grupo de Trabalho Segurança Alimentar do Instituto de Estudos Avançados da Universidade de São Paulo, São Paulo, 1994 (mimeo.).

108. MONTEIRO, C. A. "Pobreza absoluta, desnutrição e desigualdades regionais no Brasil". In: BARROS, R. P \& URANI, A. (Org.). Primeiro relatório sobre desigualdade de renda e pobreza no Brasil. Parte II: Conseqüências. IPEA, Rio de Janeiro, no prelo.

109. MONTEIRO, C. A. Recentes mudanças propostas na avaliação antropométrica do estado nutricional infantil: uma avaliação crítica. Revista de Saúde Pública, São Paulo, 18: 56-63, 1984.

110. MONTEIRO, C.A. Saúde e nutrição das crianças de São Paulo. São Paulo, Hucitec, 1988. 165 pp. 
111. MONTEIRO, C. A.; BENÍCIO, M. H. D.; GOUVEIA, N. C. "Saúde e nutriçāo das crianças brasileiras no final da década de 80". In: Monteiro, M.F.G. \& Cervini, R. (Org.): Perfil Estatístico de Crianças e Mães no Brasil - Aspectos de Saúde e Nutrição de Crianças no Brasil 1989. Rio de Janeiro, Fundaçāo Instituto Brasileiro de Geografia e Estatistica/Instituto Nacional de Alimentação e Nutrição/ Fundo das Nações Unidas para a Infância e a Adolescência, 1992. pp. 19-42.

112. MONTEIRO, C. A.; BENICIO, M. H. D.; IUNES, R.; GOUVEIA, N. C.; TADDEI, J. A. A. G. CARDOSO, M. A. A. C. ENDEF e PNSN: para onde caminha o crescimento físico da criança brasileira? Cadernos de Saúde Pública, Rio de Janeiro, 9(supl.1): 85-95, 1993.

113. MONTEIRO, C. A. BENICIO, M. H. D.; LAMONICA, I. M. R.; L'ABBATE, S.; STEFANINI, M. L. R.; OSHIRO, J. H.; PIRES, H. B.; ALVES, M. C. G. P. Avaliação do impacto da suplementação alimentar a gestantes no controle do baixo peso ao nascer no município de São Paulo, SP (Brasil). Revista de Saúde Pública, São Paulo, 19: 458-74, 1985.

114. MONTEIRO, C. A.; ZÚÑIGA, M. H.; BENICIO, M. H. A. \& VICTORA, C. G. Better prospects for child survival. World Health Forum, 10:222-7, 1989.

115. MONTEIRO, M. F. G. "Baixo peso ao nascer". In: MONTEIRO, M. F. G. \& CERVINI, R. (Org.): Perfil Estatistico de Crianças e Mães no Brasil - Aspectos de Saúde e Nutrição de Crianças no Brasil 1989. Rio de Janeiro, Fundação Instituto Brasileiro de Geografia e Estatistica/Instituto Nacional de Alimentação e Nutrição/Fundo das Nações Unidas para a Infância e a Adolescência, 1992. pp 11-8.

116. MPAS. Manual para avaliação antropométrica do estado nutricional de crianças até 7 anos de idade. Brasilia, Ministério da Previdência e Assistência Social, 1983.

117. MS. Assistência e controle das doenças diarréicas. 3" edição. Brasilia, Ministério da Saúde, 1993. $44 \mathrm{pp}$.

118. MS. Assistência integral d̀ saúde da criança: ações básicas. Brasília, Ministério da Saúde. Textos Básicos de Saúde. Centro de Documentação do Ministério da Saúde, série B: Textos básicos de saúde 7, 1984. $20 \mathrm{pp}$.

119. MS. Assistência integral à saúde da mulher: bases de ação programática. Brasilia, Ministério da Saúde, Centro de Documentação do Ministério da Saúde, série B: Textos básicos de saúde 6, 1984. 27 pp.

120. MS. Guia de vigilancia epidemiológica. Brasília, Ministério da Saúde, série A: Normas e manuais técnicos $21,1985.130 \mathrm{pp}$.

121. MS. Manual de normas para infecção respiratória aguda. 3 edição. Brasilia, Ministério da Saúde, 1991. 29 pp.

122. MS. Normas de atenção à saúde integral do adolescente. Vol. 1. Brasilia, Ministério da Saúde, 1993. $48 \mathrm{pp}$.

123. MS. Normas de atenção à saúde integral do adolescente. Vol. 2. Brasilia, Ministério da Saúde, 1993. $28 \mathrm{pp}$.

124. MS. Normas de atenção à saúde integral do adolescente. Vol. 3. Brasilia, Ministério da Saúde, 1993. $40 \mathrm{pp}$. 
125. MS. Programa de atendimento aos desnutridos e às gestantes em risco nutricional - "Leite é Saúde". Brasilia, Ministério da Saúde/Sistema Único de Saúde, 1993. 15 pp.

126. MS. Programa Nacional de Saúde do Idoso. Brasília, Ministério da Saúde, 1992. 7p. (mimeo).

127. MS. Programa Saúde do Adolescente - bases programáticas. Ministério da Saúde, Brasilia, 1989. 24 pp.

128. MS/FNS. Atendimento integrado à saúde e desenvolvimento da criança - módulo 1 : cartão da criança - instrutivo. Brasilia, Ministério da Saúde/Fundação Nacional de Saúde, 1992. 38 pp.

129. MS/GERAS. Documento básico. Brasilia, Ministério da Saúde/Grupo Executivo da Reforma Administrativa do Ministério da Saúde, 1993. 40 pp.

130. MS/INAMPS. Acompanhamento do crescimento e desenvolvimento. 3" edição. Brasilia, Ministério da Saúde/Instituto Nacional de Assistência Médica da Previdência Social, 1986. 18 pp.

131. MS/INAMPS. Aleitamento materno e orientação alimentar para o desmame. 3! edição. Brasilia, Ministério da Saúde/Instituto Nacional de Assistência Médica da Previdência Social. 1986. 22 pp.

132. MS/INAMPS. Assistência e controle das doenças diarréicas - Açōes Básicas na Assisténcia Integral à Saúde da Criança. 1' edição. Brasilia, Ministério da Saúde/Instituto Nacional de Assistência Médica da Previdência Social, 1985. 18 pp.

133. MS/INAMPS. Assisténcia e controle das infeç̧ões respiratórias agudas (IRA). 2: edição. Brasilia, Ministério da Saude/Instituto Nacional de Assistência Médica e Previdência Social, 1987. 22 pp.

134. MS/INAN. Programa Nacional de Incentivo ao Aleitamento Materno. Brasilia, Ministério da Saủde/Instituto Nacional de Alimentação e Nutrição, 1991. 43 pp.

135. MS/SAS/DPS/CDC. Doenças cardiovasculares no Brasil- Sistema Único de Saúde - SUS dados epidemiológicos, assistência médica. Brasilia, Ministério da Saúde/Secretaria de Assistência à Saúde/Departamento de Programas de Saúde/Coordenação de Doenças Cardiovasculares, 1993. $36 \mathrm{pp}$.

136. MS/SNPES/DNDCD. Manual de diabetes. Brasilia, Ministério da Saúde/Secretaria Nacional de Programas Especiais de SaúdeDivisão Nacional de Doenças Crônico-Degenerativas, 1990. $92 \mathrm{pp}$.

137. MS/SNPES/DNDCD/PNECHA. Normas técnicas para o Programa Nacional de Educação e Controle da Hipertensão Arterial. Brasília, Ministério da Saúde/Secretaria Nacional de Programas Especiais de Saúde/Divisão Nacional de Doenças Crônico-Degenerativas/Programa Nacional de Educação e Controle da Hipertensão Arterial, 1988. 89 pp.

138. MUNHOZ, D. G. Reflexos desestabilizadores dos programas de ajustamento externo. In: CHAHAD, J. P. Z. \& CERVINI, R. (Org). Crise e infância no Brasil-o impacto das politicas de ajustamento econômico. São Paulo, Instituto de Pesquisas Econômicas da Universidade de São Paulo, 1988. pp. 3-45. 
139. MUSGROVE, P. Por una mejor alimentación - evaluación de programas destinados a mejorar el consumo alimentario y el estado nutricional de familias pobres en Brasil. Washington, Organización Panamericana de la Salud/ Organización Mundial de la Salud, cuaderno técnico $25,1989$.

140. NEIRA, M. J. L. Guia de un sistema de vigilancia epidemiologica. Revista de la Escuela de Saud Publica, Córdoba, 1(2,3): 13-27, 1990.

141. NCHS. Growth curves for children birth - 18 years, United States. National Center for Health Statistics, Washington, DC: U.S. Printing Office. (Vital Health Statistics Series 11, no 781650), 1977. $74 \mathrm{pp}$.

142. NORTON, R. Maternal nutrition during pregnancy as it affects infant growth, development and health. SCN News, 11: 10-4, 1994.

143. NUTTING, P. A. Community-oriented primary care: a promising innovation in primary care. Public Health Reports, 100(1): 3-4, 1985.

144. OLIVEIRA, J. A. A. \& TEIXEIRA, S. M. F. (Im)previdéncia social - 60 anos de história da previdência no Brasil. 2ะ edição. Petrópolis, Vozes, 1989. 357 pp.

145. OLSHANSKY, S. J. \& AULT, B. A. The fourth stage of the epidemiologic transition: the age of delayed degenerative diseases. The Milbank Memorial Fund Quarterly, New York, 64(3): $355-91,1986$.

146. OMRAN, A. R. The epidemiologic transition - a theory of the epidemiology of population change. The Milbank Memorial Fund Quarterly, New York, 49(4): 509-38, 1971.

147. OMS. Funciones del sector salud en materia de alimentación y nutrición. Organización Mundial de la Salud, serie de informes técnicos 667, 1981. $100 \mathrm{pp}$.

148. OMS. Medición del cambio del estado nutricional: diretrices para evaluar el efeito nutricional de programas de alimentación suplementaria destinados a grupos vulnerables. Ginebra, Organización Mundial de la Salud, 1983. 105 pp.

149. OPS. Contribuición de la epidemiologia en el desarrollo de los programas de salud en América Latina. In: OPS/OMS. Usos y perspectivas de la epidemiologia. Washington, Organización Panamericana de la Salud/Organización Mundial de la Salud, publicación no PNSP 84-47, 1984. pp. 13-30.

150. OPS. Las condiciones de salud en las Americas, 1981-1984. Vol.1. Washington, Organización Panamericana de la Salud/Organización Mundial de la Salud, publicación cientifica 500, 1986. $442 \mathrm{pp}$.

151. OPS. Las condiciones de salud en las Americas, 1981-1984. Vol.2. Washington, Organización Panamericana de la Salud/Organización Mundial de la Salud, publicación científica 500, 1986. $282 \mathrm{pp}$.

152. OPS. Las condiciones de salud en las Americas, edición de 1990. Vol.1. Washington, Organización Panamericana de la Salud/Organización Mundial de la Salud, publicación científica $524,1990.528 \mathrm{pp}$.

153. OPS. Las Condiciones de Salud en las Americas, edición de 1990. vol.2. Washington, Organización Panamericana de la Salud/Organización Mundial de la Salud, publicación cientifica 524, 1990. $328 \mathrm{pp}$. 
154. OPS. Vigilancia alimentaria y nutricional en las Americas. Washington, Organización Panamericana de la Salud/Organización Mundial de la Salud, 1989. 217 pp.

155. OPS/OMS. Salud para Todos en el Año 2000 - estrategias. Organización Panamericana de la Salud/Organización Mundial de la salud, documento oficial 173, 1980. 339 pp.

156. OPS/OMS. Usos y perspectivas de la epidemiologia. Washington, Organización Panamericana de la Salud/Organización Mundial de la Salud, publicación no PNSP 84-47, 1984. 243 pp.

157. ORALC/FAO. Papel de la vigilancia alimentaria y nutricional en la seguridad alimentaria. Oficina Regional para America Latina y el Caribe/Food and Agriculture Organization, sd. 45 pp.

158. ORALC/FAO. Vigilancia alimentaria y nutricional y seguridad alimentaria: un enfoque funcional para America Central. Oficina Regional para America Latina y el Caribe/Food and Agriculture Organization. Red de Cooperación Técnica en Sistemas de Vigilancia Alimentaria e Nutricional. NUT-33, sd. 14 pp.

159. PAIM, J. S. \& TEIXEIRA, M. G. L. C. Reorganização do sistema de vigilância epidemiológica na perspectiva do Sistema Único de Saúde (SUS). Informe Epidemiológico do SUS, Brasilia: Ano I, n.5: 27-57, outubro, 1992.

160. PELIANO, A. M. T. M. Quem se beneficia dos programas governamentais de suplementação alimentar. Texto para Discussão, 205, Brasilia, 1990. 10pp.

161. PEliANO, A. M. T. M. (Organizadora). O Mapa da fome - subsidios à formulação de uma política de segurança alimentar. Série Documento de Politica, 14, Brasilia, Instituto de Pesquisa Econômica Aplicada, 1993.

162. PELIANO, A. M. T. M. "Os programas alimentares e nutricionais no contexto da recessão econômica: 1980-1984". In: CHAHAD, J. P. Z. \& CERVINI, R. (Org.). Crise e infancia no Brasil - o impacto das políticas de ajustamento económico. São Paụlo, Instituto de Pesquisas Econômicas da Universidade de São Paulo, 1988. pp. 185-220.

163. PELIANO, A. M. T. M. \& BEGHIN, N. O papel do Estado na área de alimentação e nutrição. Relatório Interno, 07/92, Brasilia, Instituto de Pesquisa Econômica Aplicada/ Coordenação de Politicas Sociais, 1992. 11 pp.

164. PELIANO, A.M.T.M. \& BEGHIN, N. Programas de alimentação e nutrição para as crianças e adolescentes: qual o destino? Relatório Interno, 03/92, Brasilia, Instituto de Pesquisa Econômica Aplicada/ Coordenação de Politicas Sociais, 1992. 3 pp.

165. PEREIRA, G. S. \& CASTRO, I. R. R. Consideraçōes sobre o plano de combate à fome è̀ miséria. Cadernos de Saúde Pública, Rio de Janeiro, 9(supl.1): 106-13, 1993.

166. POPKIN, B. M. The nutrition transition in low-income countries: an emerging crisis. Nutrition Reviews, 52(9): 285-98, 1994.

167. POSSAS, C. Epidemiologia e sociedade - heterogeneidade estrutural e saude no Brasil. São Paulo, Hucitec, 1989. 271 pp.

168. PRATA, P. R. A transição epidemiológica no Brasil. Cadernos de Saúde Pública, Rio de Janeiro, 8(2): 168-75, 1992. 
169. REZENDE, F. A política social e a crise econômica. In: CHAHAD, J. P. Z. \& CERVINI, R. (Org.). Crise e infáncia no Brasil - o impacto das políticas de ajustamento económico. São Paulo, Instituto de Pesquisas Econômicas da Universidade de São Paulo, 1988. pp. 111-37.

170. RISI JÚNIOR, J. B. Considerações sobre a publicação de dados epidemiológicos pelo Ministério da Saúde. Informe Epidemiológico do SUS, Brasília, Ano I, n.4: 27-32, setembro 1992.

171. RODRIGUEZ, O. La teorla del subdesarrollo de la Cepal. $7^{2}$ edición. Mexico: 1989. 367pp.

172. ROMERO, A. El desarrollo historico de la epidemiologia en America Latina. In: ABRASCO. Anais do $1^{\circ}$ Congresso Brasileiro de Epidemiologia: Epidemiologia e desigualdade social: os desafios do final do século. Rio de Janeiro, Associação Brasileira de Pós-Graduação em Saúde Coletiva, 1990. pp. 81-107.

173. ROSSO, P. A new chart to monitor weight gain during pregnancy. American Journal of Clinical Nutrition, 41: 644-52, 1985.

174. SÁ CARVALHO, M. Avaliação da prática de vigilancia epidemiológica nos serviços públicos de saúde no Brasil. Tese apresentada à Escola Nacional de Saúde Pública para obtenção do grau de mestre, Rio de Janeiro, 1990. 190 pp.

175. SÁ CARVALHO, M. \& MARZOCCHI, K. B. F. Avaliação da prática de vigilância epidemiológica nos serviços públicos de saúde no Brasil. Revista de Saúde Pública, São Paulo, 26(2): 66-74, 1992.

176. SANTOS, S. M. F. (Coord.) Projeto de implantação do Sistema de Vigilancia Alimentar e Nutricional (SISVAN) na rede de saúde do município do Rio de Janeiro. Rio de Janeiro, Secretaria Municipal de Saúde do Rio de Janeiro, 1991. (mimeo).

177. SCAFUTO, A. C. S.; AMGARTEN, C. M.; STRAUSZ, M. C.; NEUTZLING, M. A. A; ANJOS, L. A. \& WAISSMANN, W. Avaliação nutricional em serviços de atenção à saúde do trabalhador. Monografia apresentada ao final do Curso de Especialização de Saúde do Trabalhador. Centro de Estudos de Saúde do Trabalhador e Ecologia Humana/Escola Nacional de Saúde Pủblica/Fundação Oswaldo Cruz, 1992. 33 pp. (mimeo).

178. SCHEER, J. C. \& SIMS, L. S. Status of nutrition surveillance activities in 24 state and metropolitan health departments. Public Health Reports, 98(4): 349-55, 1983.

179. SCHEJTMAN, A. La seguridad alimentaria: tendencias e impacto de la crisis. Revista de la Cepal, 36: 141-62, 1988.

180. SILVA, A. C. De Vargas a Itamar - Políticas e programas de alimentação e nutrição. Texto apresentado no Seminário "Pobreza, fome e desnutrição no Brasil", organizado pelo Grupo de Trabalho Segurança Alimentar do Instituto de Estudos Avançados da Universidade de São Paulo, São Paulo, 1994 (mimeo.).

181. SILVA, L. I. L. \& SILVA, J. G. Política nacional de segurança alimentar - versão resumida. Governo Paralelo, outubro de 1991.

182. SIMŐES, C. C. S. "O estudo dos diferenciais na mortalidade infantil segundo algumas caracteristicas sócio-econômicas". In: MONTEIRO, M. F. G. \& CERVINI, R. (Org.): Perfil Estatístico de Crianças e Mães no Brasil - Aspectos de saúde e nutrição de crianças no Brasil 1989. Rio de Janeiro, Fundação Instituto Brasileiro de Geografia e Estatistica/Instituto Nacional de Alimentação e Nutrição/Fundo das Nações Unidas para a Infância e a Adolescência, 1992. pp. 61-78. 
183. SMS-SANTOS. Sistema de vigilancia do recém-nascido de risco. Secretaria Municipal de Saúde de Santos, informativo no 1, 1991. 21 pp. (mimeo).

184. SMS-RJ. O direito de nascer direito. Saide em Foco, Rio de janeiro, ano III, 7: 3-7, Secretaria Municipal de Saúde do Rio de Janeiro, 1993.

185. SMS-RJ/UFRJ/UNIRIO/UGF/CAN-SOPERJ. Orientações alimentares básicas para o desmame e o pré-natal. Secretaria Municipal de Saúde do Rio de Janeiro/Universidade Federal do Rio de Janeiro/Universidade do Rio de Janeiro/Universidade Gama Filho/Comitê Assessor de Nutrição da Sociedade de Pediatria do Estado do Rio de Janeiro, 1994. (mimeo).

186. SZWARCWALD, C. L.; CHEQUER, P. \& CASTILHO, E. A. Tendências da mortalidade infantil no Brasil nos anos 80. Informe Epidemiológico do SUS, Brasilia: Ano I, n.2: 35-50, julho, 1992.

187. TADDEI, J. A. A. C. et al. Relatório do estudo multicêntrico visando validar a curva de ganho ponderal da gestante. Brasilia, 1988.

188. TANNER, J. M. Growth at adolescence. $2^{\text {nd }}$ edition, Oxford, Blackwell Scientific Publication, 1962.

189. TAYLOR, C. E. Surveillance for equity in primary health care: policy implications from international experience. International Journal of Epidemiology, 21(6): 1043-9, 1992.

190. TERRIS, M. The epidemiologic revolution, national health insurance and the role of health departments. American Journal of Public Health, 66(12): 1155-64, 1976.

191. THACKER, S. B. \& STROUP, D. F. Future directions for comprehensive public health surveillance and health information systems in the United States. American Journal of Epidemiology, 140(5): 383-97, 1994.

192. TROWBRIDGE, F. L.; WONG, F. L.; BYERS, T. E.; SERDULA, M. K. Methodological Issues in Nutrition Surveillance: The CDC Experience. Journal of Nutrition, 120(11 suppl): 1512-8, 1990.

193. UNGER, J. P. \& DUJARDIN, B. Epidemiology's contribution to health service management and planning in developing countries: a missing link. Bulletin of the World Health Organization, 70(4): 487-97, 1992.

194. UNICEF. Estratégia para melhorar a nutrição de crianças e mulheres nos paises em desenvolvimento. Fundo das Nações Unidas para a Infância e Adolescência, New York, 1990. 38 pp.

195. VALENTE, F. L. S. Contribuição para o plano de desenvolvimento do Sistema de Vigilancia Alimentar e Nutricional no Brasil-documento preliminar. 1987. 21 pp. (mimeo).

196. VALENTE, F. L. S. (Org.) Fome e desnutrị̧ão - determinantes sociais. São Paulo, Cortez, 1986. $107 \mathrm{pp}$.

197. VASCONCELOS, F. A. G. A política social de alimentação e nutrição no Brasil: acumulação de capital e reprodução da fome/desnutrição. Saúde em Debate, Londrina, 23: 42-9, 1988.

198. VASQUEZ, P. V. "Usos de la epidemiologia en la vigilancia y control de las enfermidades en general". In: OPS/OMS. Usos y perspectivas de la epidemiologia. Washington, Organización Panamericana de la Salud/Organización Mundial de la Salud, publicación PNSP 84-47, 1984. pp. 48-56. 
199. VAUCHAN, J. P. \& MORROW, R. H. Epidemiologia para os municipios - manual para gerenciamento dos distritos sanitários. São Paulo, Hucitec, 1992. 180 pp.

200. VICTORA, C. G.; BARROS, F. C. \& VAUGHAN, J. P. Epidemiologia da desigualdade. 2: edição. São Paulo, Hucitec, 1989. 187 pp.

201. VIO, F.; KAIN, J. \& VIAL, 1. Evaluación del sistema de información en salud y nutrición llamado "SISVAN"de Chile. Revista Chilena de Nutrición, Santiago, Chile, 10(3): 181-8, 1991.

202. WALL, S. G. I. Epidemiology in developing countries - some experiences from collaboration across disciplines and cultures. Scandinavian Journal of Social Medicine, (supl. 46): 25-32.

203. WATERLOW, J. C.; BUZINA, R.; KELLER, W.; LANE, S. M.; NICHAMAN, M. Z. The presentation and use of height and weight data for comparing the nutritional status of groups of children under the age of 10 years. Bulletin of World Health Organization, 55: 489-98, 1977.

204. WESTERN, K. A. Organización y administración de los programas de control de las enfermidades en los paises en desarrollo. Boletín de la Oficina Sanitaria Panamericana, 89(5): 381$96,1980$.

205. WHO/UNICEF. Primary health care. Joint Report by the Director-General of the World F i.ich Organization and the Executive Director of theUnited Nations Children's Found for the International Conference on Primary Health Care - Alma-Ata, URSS, Switzerland, 1978.

206. WHO WORKING GROUP. Use and interpretation of anthropometric indicators of nutritional status. Bulletin of World Health Organization, 564: 929-41, 1986.

207. WOTEKI, C. E. \& FANELLI-KUCZMARSKI, M. T. 50. El sistema nacional de vigilancia de la nutrición. In: OPS/ILSI. Conocimientos actuales sobre nutrición, Washington, Organización Panamericana de la Salud/Instituto Internacional de Ciencias de la Vida, publicación cientifica 532, 1991. pp. 480-98. 
Trata-se de uma publicação de elevado alcance pragmático, na medida em que questiona e fornece elementos de decisão para os formuladores de politicas, planejadores e executores de programas e atividades de alimentação e nutrição, especialmente no contexto do setor saúde.

Aqueles que fazem o SISVAN no Brasil e na América Latina devem consultar este livro como uma referência obrigatória para se posicionar face às questões e desafios desta proposta, no sentido de se evitar o apriorismo "politicamente ingênuo, operacionalmente ambicioso, embora teoricamente elegante" mencionado pela Food and Agriculture Organization, numa observação crítica sobre o modelo convencional da planificação nutricional na America Latina e até no mundo. 
$\mathrm{V}$ igilância Alimentar e Nutricional: Limitações $\boldsymbol{e}$ Interfaces com a Rede de Saúde é uma publicação de elevado alcance pragmático, na medida em que questiona e fornece elementos de decisões para os formuladores de políticas, planejadores e executores de programas e atividades de alimentação e nutrição, especialmente no setor saúde.

\footnotetext{
- sta obra consolida a contribuição brasileira no campo ainda indefinido da vigilância alimentar e nutricional e tem todas as condições para se converter em um marco historiográfico do tema.
} 